Article

\title{
Design, Synthesis and Biological Evaluation of 7-Chloro-9H-pyrimido[4,5-b]indole-based Glycogen Synthase Kinase- $3 \beta$ Inhibitors
}

\author{
Stanislav Andreev ${ }^{1}$, Tatu Pantsar ${ }^{2,3}$, Francesco Ansideri ${ }^{1}$, Mark Kudolo ${ }^{1}$, Michael Forster ${ }^{1}$, \\ Dieter Schollmeyer ${ }^{4}$, Stefan A. Laufer ${ }^{1}$ (i) and Pierre Koch ${ }^{1,5, *(D)}$ \\ 1 Institute of Pharmaceutical Sciences, Department of Medicinal and Pharmaceutical Chemistry, Eberhard \\ Karls University Tübingen, Auf der Morgenstelle 8, 72076 Tübingen, Germany; \\ stanislav.andreev@uni-tuebingen.de (S.A.); francesco.ansideri@uni-tuebingen.de (F.A.); \\ Mark.Kudolo@uni-tuebingen.de (M.K.); Michael.forster@uni-tuebingen.de (M.F.); \\ Stefan.laufer@uni-tuebingen.de (S.A.L.) \\ 2 Department of Internal Medicine VIII, University Hospital Tübingen, Otfried-Müller-Str. 14, \\ 72076 Tübingen, Germany; tatu.pantsar@uef.fi \\ 3 School of Pharmacy, University of Eastern Finland, P.O. Box 1627, 70211 Kuopio, Finland \\ 4 Department of Organic Chemistry, Johannes Gutenberg University Mainz, Duesbergweg 10-14, 55099 Mainz, \\ Germany; scholli@uni-mainz.de \\ 5 Department of Pharmaceutical/Medicinal Chemistry II, Institute of Pharmacy, University of Regensburg, \\ Universitätsstraße 31, 93053 Regensburg, Germany \\ * Correspondence: pierre.koch@uni-tuebingen.de; Tel.: +49-7071-29-74579
}

Academic Editor: Christian Peifer

Received: 23 May 2019; Accepted: 20 June 2019; Published: 25 June 2019

check for updates

\begin{abstract}
Glycogen synthase kinase-3 $\beta$ (GSK-3 $\beta$ ) represents a relevant drug target for the treatment of neurodegenerative pathologies including Alzheimer's disease. We herein report on the optimization of a novel class of GSK-3 $\beta$ inhibitors based on the tofacitinib-derived screen hit 3-((3R,4R)-3-((7-chloro-9H-pyrimido[4,5-b]indol-4-yl)(methyl)amino)-4-methylpiperidin-1-yl)-3oxopropanenitrile (1). We synthesized a series of 19 novel 7-chloro-9H-pyrimido[4,5-b]indole-based derivatives and studied their structure-activity relationships with focus on the cyanoacetyl piperidine moiety. We unveiled the crucial role of the nitrile group and its importance for the activity of this compound series. A successful rigidization approach afforded 3-(3aRS,7aSR)-(1-(7-chloro-9H-pyrimido[4,5-b]indol-4-yl)octahydro-6H-pyrrolo[2,3-c]pyridin-6-yl)propanenitrile (24), which displayed an $\mathrm{IC}_{50}$ value of $130 \mathrm{nM}$ on GSK-3 $\beta$ and was further characterized by its metabolic stability. Finally, we disclosed the putative binding modes of the most potent inhibitors within the ATP binding site of GSK-3 $\beta$ by $1 \mu$ s molecular dynamics simulations.
\end{abstract}

Keywords: Glycogen synthase kinase-3 $\beta$; 7-chloro-9H-pyrimido[4,5-b]indole; protein kinase; kinase inhibitor; tofacitinib

\section{Introduction}

The human kinome represents a collective of over 500 genes dedicated to the sophisticated signaling networks in human cells [1]. With the majority of protein kinases being catalytically active, hence capable of transferring the $\gamma$-phosphate group from ATP/GTP to their protein substrates, this enzyme group is assumed to modify up to $30 \%$ of the intracellular proteome by phosphorylation [2]. While certain kinases target a limited number of substrates and consequently play a distinct role in cell signaling, others act as multitasking players in the cell circuitry. With over 30 proposed substrates glycogen synthase kinase-3 (GSK-3) clearly joins the ranks of the latter class [3]. Its name 
is attributed to the inhibition on glycogen synthesis within the frame of intracellular insulin signal transduction [4-6], yet not fully reflects the wide-ranging tasks of GSK-3 within the cell. The two isoforms of this serine/threonine kinase, namely GSK-3 $\alpha$ and GSK-3 $\beta$, differ in their C- and N-termini, while their kinase domains are highly conserved and characterized by $98 \%$ homology [7]. Despite their similarities, knock-out experiments in mice as well as numerous pharmacological studies have questioned the complete redundancy of these two paralogs [8-11].

GSK-3 is ubiquitously expressed and involved in at least five different signaling pathways (Insulin, Wnt, Notch, Hedgehog and TGF- $\beta$ ). This raises the question on how proper regulation mechanisms guarantee the flawless functionality of this enzyme [12]. A dysregulated GSK-3 activity has been linked to the development of several pathologies such as cancer, diabetes, CNS disorders, and neurodegeneration [11]. Thus, being a potential therapeutic target, GSK-3 has received attention of pharmaceutical research. Despite decades of extensive research efforts, several questions regarding the intracellular impact of this kinase, the mechanisms ensuring its regulation as well as its validity as a drug target remain unanswered. This has caused a strong demand for chemical agents, which can serve as chemical probes in pharmacological and biochemical studies and also as starting points for the development of clinical candidates.

In this context, we herein present a novel class of 7-chloro-9H-pyrimido[4,5- $b$ indole-based GSK-3 $\beta$ inhibitors. The compound series is derived from the pan-Janus kinase (JAK) inhibitor tofacitinib (Scheme 1), formerly known as CP-690,550. The main target of tofacitinib is JAK3 [13]. This non-receptor tyrosine kinase is expressed exclusively in lymphoid cells, where it transduces the signals of $\gamma$-common cytokines in the course of the JAK-STAT signaling pathway [13,14]. A pharmacological intervention in this pathway with tofacitinib is used in the treatment of immunological disorders such as rheumatoid or psoriatic arthritis [15]. In the course of a kinome-wide screening campaign of our in-house compound library, the tofacitinib-derived 7-chloro-9H-pyrimido[4,5-b]indole $\mathbf{1}$ was identified as a GSK-3 $\beta$ inhibitor in the single-digit micromolar range (Scheme 1). Interestingly, GSK-3 $\beta$ and JAK3 are located in different branches of the phylogenetic kinome tree. They are structurally diverse, even their kinase domains display low homology (identity 22.6\%) (Figure S1, Supplementary Materials).

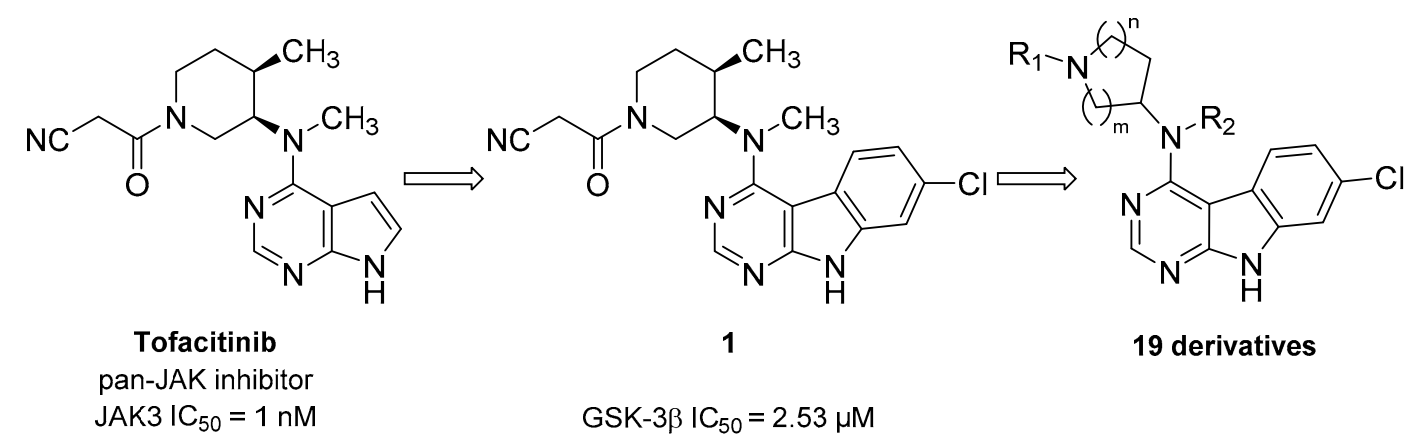

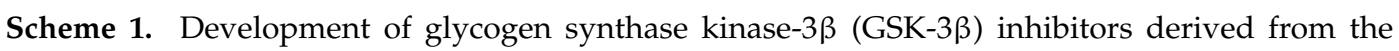
pan-Janus kinase (JAK) inhibitor tofacitinib.

In this work, we describe a medicinal chemistry strategy consisting of the design, synthetic preparation and biological evaluation of a series of compounds dedicated to an optimization of hit 1 towards GSK-3 $\beta$ inhibition. Interpretation of the biological data combined with in silico approaches provides insight into structure-activity relationships (SARs) and the putative binding mode of this novel class of GSK-3 $\beta$ inhibitors. Finally, the most promising inhibitors were further characterized by their metabolic stability in human liver microsomes (HLM) and inhibitory activity on JAK3, which is the main target of tofacitinib. 


\section{Results and Discussion}

\subsection{Biological Evaluation}

The binding mode of JAK3 in complex with tofacitinib (PDB ID: 3LXK) has been resolved (Figure 1) [16]. The 7H-pyrrolo[2,3- $d$ ]pyrimidine moiety of tofacitinib forms a bidentate hydrogen bond to the hinge residues Glu903 and Leu905, whereas the N-3 atom of the pyrimidine ring displays an interaction with a crystal water molecule. The ribose region of the kinase accommodates the piperidine ring of the inhibitor, allowing the exocyclic methyl group to occupy a miniscule lipophilic cavity in the bottom of the catalytic cleft formed by Ala966, Cys909, and Leu956. Consequently, this positioning of the methyl group leads to an orientation of the nitrile residue towards the glycine-rich loop.

(a)

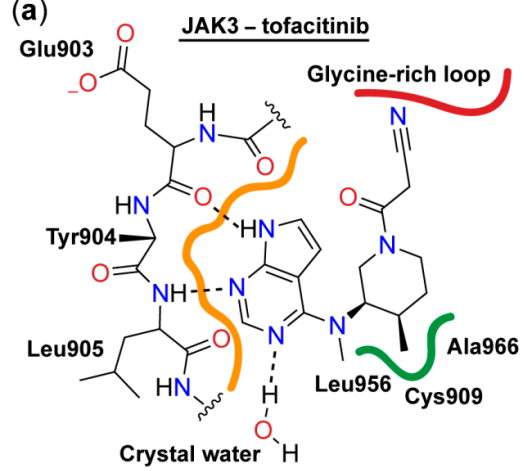

(b)

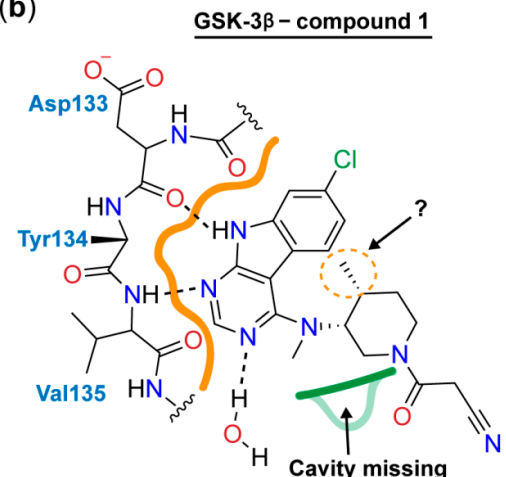

(c)

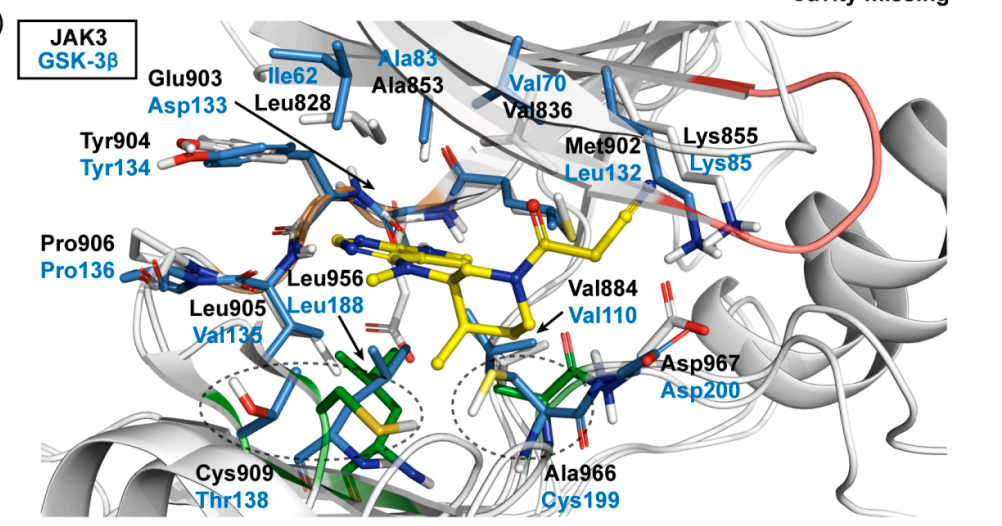

Figure 1. Schematic 2D representation of the binding mode of tofacitinib to JAK3 derived from its co-crystal structure (PDB ID: 3LXK) [16] (a) and the expected binding mode of 1 to GSK-3 $\beta$ (b). The lipophilic cavity is highlighted with green and the hinge region with orange. Hydrogen bonds are depicted as dashed lines. (c) 3D superposition based on the hinge regions of GSK-3 $\beta$ (PDB ID: 4PTC) and JAK3 (PDB ID: 3LXK) shows a high conservation of the residues in the ATP binding site [17]. The lipophilic cavity is missing in GSK-3 $\beta$, as the spatial orientation of the Thr138 is totally different compared to the Cys909 in JAK3 and the residue Cys199 is bulkier than the Ala966 found in JAK3. Moreover, this Cys199 would clash with tofacitinib (yellow) in its JAK3 binding conformation. Residues near to tofacitinib are depicted as sticks. The stick coloring is the following: GSK-3 $\beta$, blue; JAK3, grey; JAK3 residues forming the lipophilic cavity, green. The cartoon coloring is the following: hinge regions, orange; lipophilic cavity residues, green; JAK3 glycine-rich loop, red.

Taking into account the high conservation of the ATP binding site, we expected a similar hydrogen bonding pattern to occur for the 7-chloro- $9 H$-pyrimido[4,5- $b$ ]indole substructure in 1 with the hinge region of GSK-3 $\beta$ (Figure 1). Therefore, we decided to leave the chlorinated tricycle unmodified and set the focus of our optimization study on the aliphatic piperidine side chain. The distinct configuration of the two stereocenters within this moiety is a prerequisite for potent JAK3 inhibition and requires laborious steps in the enantiopure preparation of tofacitinib and hit $\mathbf{1}$, respectively [18]. However, in 
contrast to JAK3, GSK-3 $\beta$ lacks a comparable lipophilic cavity in the bottom of its ATP binding site (Figure 1), which questioned the necessity of the corresponding exocyclic methyl group. This motivated us to prepare 14a (Table 1). This compound, lacking the methyl substituent, has one stereocenter less and was prepared as racemic mixture. This approach simplified the synthetic preparation significantly. The racemic 14a was found to exhibit a similar inhibitory activity on GSK-3 $\beta$ as 1, justifying the selected approach, and was therefore chosen as a starting point for the development of further derivatives.

At first, we evaluated the importance of the carbonyl group within the cyanoacetamide moiety. Tertiary amine $\mathbf{1 4 b}$, which lacks the carbonyl group of $\mathbf{1 4 a}$, exhibited a 2.5 -fold increase in activity. The molecular structures of $\mathbf{1 4 b}$ and its amide counterpart display critical differences in their chemical properties. The loss of a possible hydrogen bond acceptor, a highly increased basicity of the piperidine nitrogen, as well as an enhanced flexibility of the cyanoethyl substituent provide putative explanations for the enhanced biological activity. With regard to this affinity shift into the nanomolar range this tertiary amine was assigned as the lead compound of this optimization study.

Next, we installed a methyl group on the indole nitrogen of $\mathbf{1 4 b}$. The resulting compound 14o, uncapable of donating a hydrogen bond with its indole nitrogen, was inactive on GSK-3 $\beta$. This negative outcome supported our hypothesis concerning the hydrogen bonding interactions of the 7-chloro-9H-pyrimido[4,5- $b$ ]indole scaffold to the hinge backbone of GSK-3 $\beta$.

With this data in hand, our attention was refocused on the piperidine ring to assess the effects of the substituent $\mathbf{R}_{\mathbf{1}}$ (Table 1 ). In order to examine the chemical space around the cyanoethyl moiety of the lead compound $\mathbf{1 4 b}$, we prepared a series of diverse tertiary amines (14c-n). Our initial approaches consisted of the application of linear and branched lipophilic substituents such as propyl (14e), isopropyl (14f), cyclopentyl (14g), and cyclopropylmethyl (14m). The corresponding compounds displayed a severe decrease in activity on GSK-3 $\beta$, which clearly indicates that aliphatic hydrocarbon substituents are not tolerated in this position. Within this inactive quartet, it is worth highlighting compound 14e, whose propyl substituent maintains similar steric properties as in 14b, however, 14e lacks the nitrile group. Therefore, the significantly decreased activity of $\mathbf{1 4} \mathbf{e}$ accentuates the importance of this functional group.

In order to disclose the vital role of the nitrile group for the activity of $\mathbf{1 4 b}$, we considered the following effects which can originate from its functionality. First, owing to the polarization of the triple bond, its nitrogen can serve as hydrogen bond acceptor. Such interactions have been observed in a number of nitrile-containing pharmaceuticals $[19,20]$. To evaluate this hypothesis, diverse substituents containing hydrogen bond acceptors, assigned to mimic the crucial nitrile group, were introduced on the piperidine nitrogen. These included both (hetero)aromatic rings like furane, pyridine or cyanobenzene in compounds $\mathbf{1 4 h}-\mathbf{j}$, as well as carbonyl group-containing moieties (14c and $\mathbf{1 4 d})$. Surprisingly, all of these modifications were associated with a dramatic decrease in activity. Even compound 14n, bearing a dimethylaminopropyl substituent, showed remarkably reduced GSK-3 $\beta$ inhibition. 
Table 1. Structures, biological activity and calculated $\mathrm{pK}_{\mathrm{a}}$ values of piperidine derivatives 14a-o.

\begin{tabular}{|c|c|c|c|c|}
\hline & & $\begin{array}{l}N \\
1 \\
\mathbf{R}_{\mathbf{2}}\end{array}$ & & \\
\hline Cpd. & $\mathbf{R}_{1}$ & $\mathbf{R}_{\mathbf{2}}$ & $\begin{array}{c}\mathrm{IC}_{50}(\mu \mathrm{M}) \\
\text { Mean } \pm \text { SEM } \\
\text { GSK-3 } \beta^{\mathrm{a}}\end{array}$ & $\mathrm{pK}_{\mathrm{a}}{ }^{\mathrm{c}}$ \\
\hline $14 a$ & & $-\mathrm{H}$ & $1.862 \pm 0.113$ & - \\
\hline $14 \mathrm{~b}$ & & $-\mathrm{H}$ & $0.764 \pm 0.203^{b}$ & 5.5 \\
\hline $14 \mathrm{c}$ & & $-\mathrm{H}$ & $>10$ & 6.8 \\
\hline $14 d$ & & $-\mathrm{H}$ & $>10$ & 6.8 \\
\hline $14 \mathrm{e}$ & & $-\mathrm{H}$ & $>10$ & 7.5 \\
\hline $14 \mathrm{f}$ & & $-\mathrm{H}$ & $>10$ & 8.3 \\
\hline $14 \mathrm{~g}$ & & $-\mathrm{H}$ & $>10$ & 8.0 \\
\hline $14 \mathrm{~h}$ & & $-\mathrm{H}$ & $>10$ & 6.9 \\
\hline $14 \mathrm{i}$ & & $-\mathrm{H}$ & $>10$ & 6.2 \\
\hline $14 j$ & & $-\mathrm{H}$ & $>10$ & 6.3 \\
\hline $14 \mathrm{k}$ & & $-\mathrm{H}$ & $>10$ & 5.7 \\
\hline 141 & & $-\mathrm{H}$ & $>10$ & 2.5 \\
\hline $14 \mathrm{~m}$ & & $-\mathrm{H}$ & $>10$ & 7.8 \\
\hline $14 n$ & & $-\mathrm{H}$ & $3.557 \pm 0.664$ & 7.2 \\
\hline 140 & & $-\mathrm{CH}_{3}$ & $>10$ & n.d. ${ }^{d}$ \\
\hline
\end{tabular}

${ }^{\mathrm{a}} \mathrm{IC}_{50}$ values were determined in an ADP Glo kinase assay [21,22], $n=2 ;{ }^{\mathrm{b}} n=5 ;{ }^{\mathrm{c}} \mathrm{pK}_{\mathrm{a}}$ value for the piperidine nitrogen calculated with Jaguar (Schrödinger LLC) (for details see Materials and Methods); ${ }^{\mathrm{d}}$ not determined.

At first glance, these findings might lead to the assumption of a hydrogen bond interaction being improbable for the nitrile group. However, the uniqueness of this functionality in terms of its rod-shaped geometry, resulting from the sp-hybridization of the carbon-nitrogen bond, must clearly be considered when interpreting these results. Most probably, the geometric and/or steric configuration of the other applied hydrogen bond-accepting substituents were not tolerated by the target enzyme.

Furthermore, taking into account that a nitrile group can significantly lower the electron density of atoms in its close proximity, we investigated the impact of the substituents on the basicity of the 
piperidine nitrogen. To this end, we calculated $\mathrm{pK}_{\mathrm{a}}$ values for the piperidine nitrogen in compounds $\mathbf{1 4} \mathbf{b}-\mathbf{j}$ and $\mathbf{1 4} \mathbf{m}-\mathbf{n}$ (Table 1). The majority of $\mathrm{pK}_{\mathrm{a}}$ values for this tertiary amine collective falls in the range between 6.8 and 8.3 predicting a significant degree of protonation of the nitrogen at $\mathrm{pH} 7.4$. In contrast, $14 \mathrm{~b}$ was assigned with a significantly lower value of 5.5 , which thoroughly reflects the electron withdrawing effects of the nitrile group and suggests a dominating presence of the uncharged free base under the physiological $\mathrm{pH}$. This can be of great relevance for the binding of $14 \mathbf{b}$ to GSK-3 $\beta$. For instance, if the lone pair of the piperidine nitrogen is directed towards positively charged residues of the enzyme, a protonation would result in repulsion.

In this context, we hypothesized that the lowered $\mathrm{pK}_{\mathrm{a}}$ and therefrom resulting unprotonated piperidine nitrogen might be an explanation for the significantly higher affinity of $\mathbf{1 4 b}$. To pursue this theory, we installed proper substituents on the piperidine nitrogen with the aim to lower the $\mathrm{pK}_{\mathrm{a}}$ in a similar manner. A bioisosteric replacement of the nitrile with a highly electron withdrawing trifluoromethyl group afforded compound 14k. In contrast, the nitrile group was maintained in compound 141, but is located closer to the piperidine nitrogen than in $\mathbf{1 4 b}$, amplifying its influence on the basicity. Even though the $\mathrm{pK}_{\mathrm{a}}$ values of these molecules are in agreement with the original intentions (5.7 and 2.5, respectively), both derivatives were found to be inactive in the kinase assay. These negative results allowed us the conclusion that the protonation state of the piperidine nitrogen cannot solely determine the nanomolar activity of $\mathbf{1 4 b}$. Additionally, the drop in activity seen with 141 points out that a specific distance between the nitrile group and the piperidine nitrogen is of utmost importance and once more emphasizes the cyanoethyl residue as preferred substituent in this position.

The outcomes with the above described set of derivatives encouraged us to keep the essential cyanoethyl moiety intact during the upcoming optimization steps. Taking into account that a proper position of the nitrile group was revealed a prerequisite for binding affinity, we attempted to fine-tune the orientation of the cyanoethyl substituent by modifications of the piperidine ring.

Alteration of the heterocyclic ring size to a pyrrolidine or azepane as well as relocation of the inner cyclic nitrogen within the piperidine delivered compounds 15-17. These modifications resulted in marginal shifts in the orientation of the essential cyanoethyl substituent. However, the derivatives 15-17 did not conserve the nanomolar activity of the parent compound 14b, which highlighted the original piperidine as the optimal scaffold within this series to properly orientate the cyanoethyl moiety. Therefore, we decided to return to this saturated heterocycle and considered rigidization approaches with the idea of stabilizing a bioactive conformation of this moiety. The bicyclic octahydro-1H-pyrrolo[2,3-c]pyridine side chain present in compound 24 was chosen for its chemical feasibility. This compound displayed an $\mathrm{IC}_{50}$ value of $130 \mathrm{nM}$, which equals a 6-fold increase in potency compared to its unrigidized counterpart 14b. It is worth noticing, that the extended hydrocarbon scaffold of 24 results in an expanded lipophilic surface area of the molecule, which enables the possibility of its improved inhibition to be driven by entropic effects. However, this is not reflected by the calculated lipophilic ligand efficiency (cLLE) values of this series (Table 2). In turn, it appears plausible that the cyanoethyl substituent is forced into a favorable direction due to the restricted rotation of the piperidine ring. 
Table 2. Structures, biological activity and AlogP-derived lipophilic ligand efficiencies (cLLE) of compounds 14b, 15-17 and 24.

16

a $\overline{\mathrm{IC}_{50} \text { values were determined in an ADP Glo assay [21,22], } n=2{ }^{\mathrm{b}} n=5{ }^{\mathrm{c}} n=3 \text {; }^{\mathrm{d}} \text { calculated with Canvas }}$ (Schrödinger LLC) [23]; ${ }^{\mathrm{e}} \mathrm{cLLE}=\mathrm{pIC}_{50}-\mathrm{Alog} \mathrm{P}$.

\subsection{Molecular Modelling}

For the better understanding of the binding and interactions of our compounds to GSK- $3 \beta$, we conducted $1 \mu$ s molecular dynamics (MD) simulations for the most potent compounds $\mathbf{1 4} \mathbf{b}$ and $\mathbf{2 4}$ (for full movies and raw data see Supplementary Materials).

Throughout the simulations, the 7-chloro-9H-pyrimido[4,5-b]indole scaffold of both ligands exhibits stable interactions with the backbone of the hinge residues Asp133 and Val135 (Figure 2), while the halogen-substituted third aromatic ring of the scaffold is pointing towards the hydrophobic region I of the kinase. 


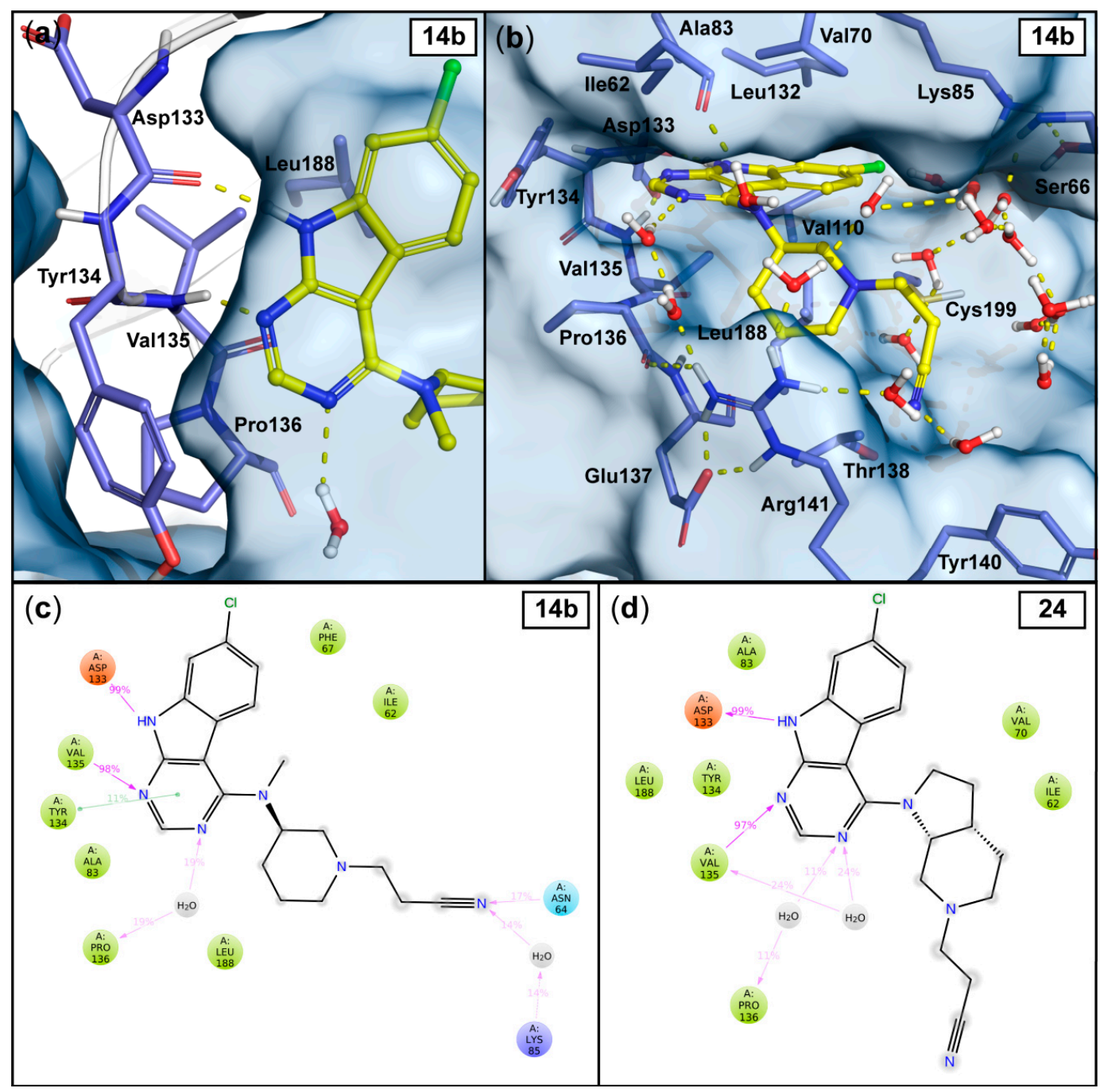

Figure 2. Observed interactions in the $1 \mu \mathrm{s}$ MD simulations with the most potent compounds $\mathbf{1 4 b}$ and 24. The output conformation of compound $\mathbf{1 4 b}$ (at $1000 \mathrm{ns)}$ ) illustrates the stable hinge interactions with the Asp133 and Val135 and to the solvent (similar in 24) (a), as well as the solvent exposure of the cyanoethyl moiety (b). Hydrogen bonds are depicted as yellow dashed lines and the water molecules within $4 \AA$ from the ligand are shown. The simulation interaction frequencies of compound $\mathbf{1 4 b}$ (c) and compound 24 (d) were analyzed using the stabilized part of the simulations: 50-1000 ns and 30-1000 ns for $\mathbf{1 4 b}$ and 24, respectively (see Figure $3 c-d$ ). Interactions that appeared with more than $10 \%$ frequency are shown; hydrogen bonds are depicted as purple arrows, $\pi-\pi$ interactions are depicted as green lines. 
(a)
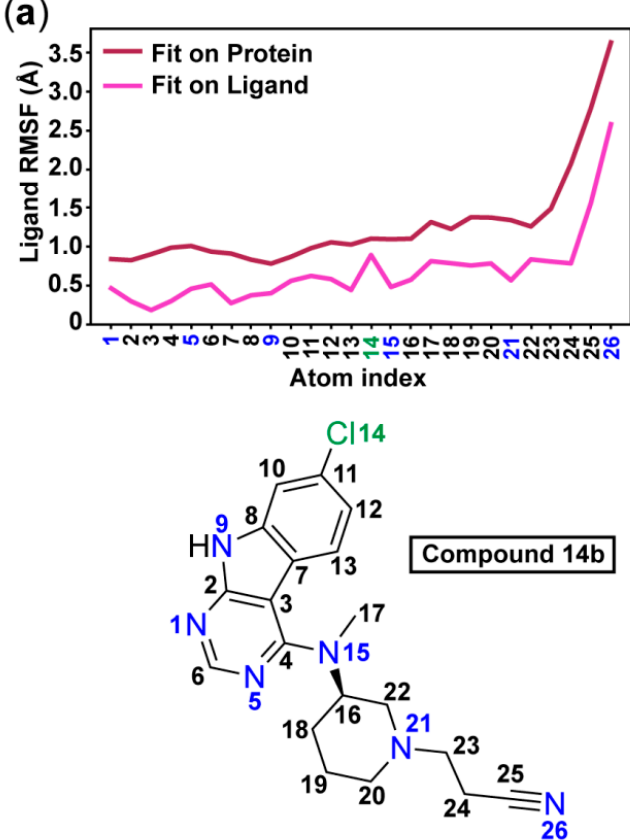

(c)

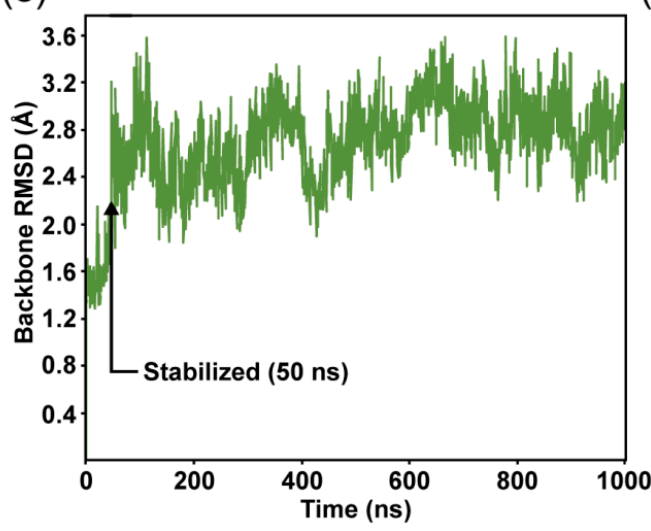

(b)

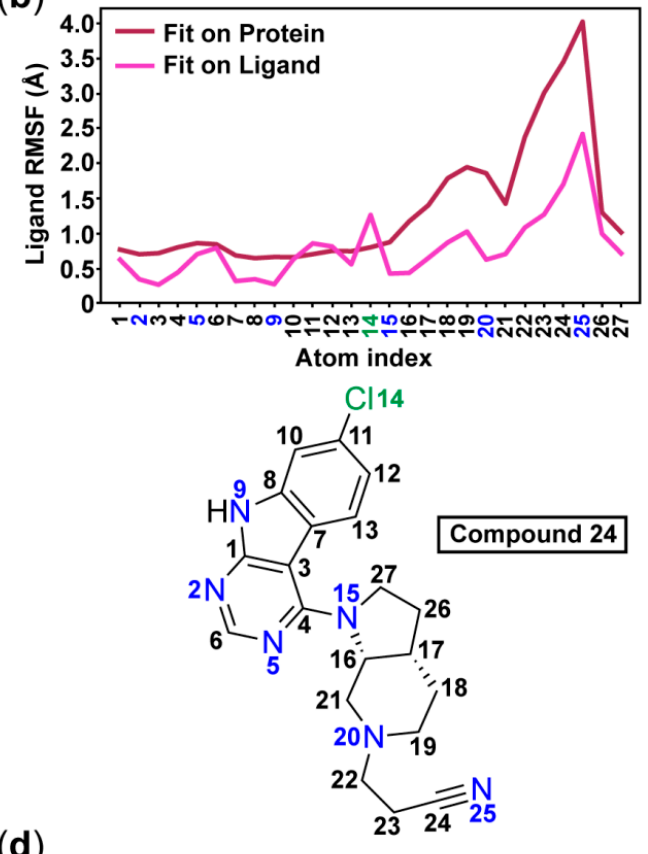

(d)

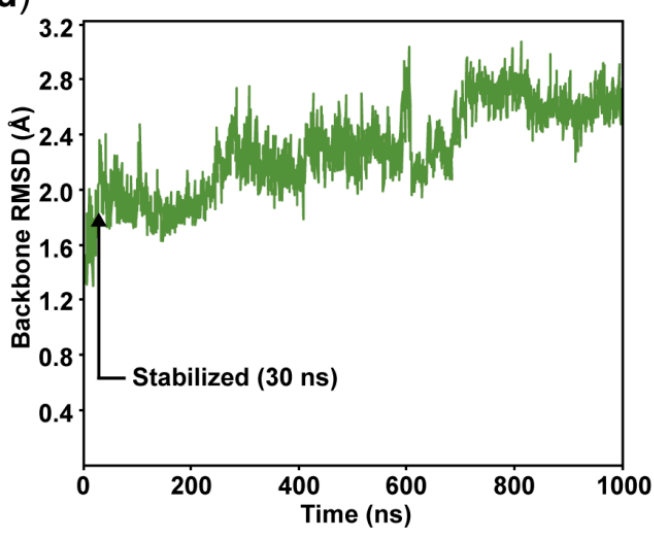

Figure 3. The root-mean-square fluctuations (RMSF) of the ligands $\mathbf{1 4 b}$ (a) and $\mathbf{2 4}$ (b) illustrate the high flexibility of the cyanoethyl moieties throughout the simulations. The root-mean-square deviation (RMSD) of the protein shows that the simulations stabilize after 50 ns with compound $\mathbf{1 4 b}$ (c) and after 30 ns with compound $24(\mathbf{d})$.

In analogy to the observed crystal water interaction in the tofacitinib-JAK3 complex (see Figure 1), relatively stable water interactions were evident for the N-3 atom in the pyrimidine ring of our inhibitors (Figure 2). Additionally, a $\pi-\pi$ interaction between this pyrimidine ring and the side chain of hinge residue Tyr134 appears in $11 \%$ frequency with $\mathbf{1 4 b}$. As expected, the sugar pocket is occupied by the piperidine heterocycle in case of $\mathbf{1 4 \mathbf { b }}$ or the octahydro- $1 \mathrm{H}$-pyrrolo[2,3-c]pyridine bicycle in case of $\mathbf{2 4}$. While the hinge binding motifs of $\mathbf{1 4 b}$ and $\mathbf{2 4}$ appear stable throughout the simulations, the cyanoethyl substituent is highly dynamic. These observations are well reflected by the ligand root-mean-square fluctuation (RMSF) for both ligands (Figure 3a-b). As far as the nitrile group is concerned, no single stable and specific interaction is observed. Rather a proper accommodation of the nitrile in the water interaction network is evident for both $\mathbf{1 4 b}$ and $\mathbf{2 4}$. A water-mediated interaction towards Lys 85 as well as a direct hydrogen bond to Asn64 occurs in case of $\mathbf{1 4 b}$, however with relatively low frequencies (Figure 2c-d).

To disclose potential differences in the binding mode of the enantiomers of compound 24, we conducted a $1 \mu \mathrm{s}$ MD simulation also for the other enantiomer of $\mathbf{2 4}(3 \mathrm{a} R, 7 \mathrm{a} S)$. As comparable behavior 
between the enantiomers was observed (Figure S2, Supplementary Materials), we expect a similar binding mode to occur with compound 24 regardless of the enantiomer.

Overall, examples of nitrile groups functioning as hydrogen bond acceptors in ligand-protein complexes are described in literature including well-characterized examples of direct contacts to asparagine residues, as well as interactions mediated through water bridges $[19,20]$. Therefore, the interactions observed in the simulations appear plausible despite their low frequencies. Finally, although we used the most recent state-of-the-art force field for drug-like small molecules, OPLS3e [24], a potential inaccuracy in the characterization of the cyanoethyl group by the force field needs to be considered (e.g., lack of polarization).

\subsection{ATP competition, JAK3 Inhibition, and Metabolic Stability}

To extend the biological profile of this novel class of 7-chloro-9H-pyrimido[4,5-b]indole-based GSK-3 $\beta$ inhibitors, we tested the lead compound $\mathbf{1 4 b}$ for its ATP competition in our ADP Glo assay system. An incubation of $\mathbf{1 4 b}$ with an increased concentration of ATP $(100 \mu \mathrm{M}$ and $500 \mu \mathrm{M})$ resulted in a reduced inhibition potential for GSK-3 $\beta$. The corresponding $\mathrm{IC}_{50}$ values were determined as $2.684 \mu \mathrm{M}$ and $9.260 \mu \mathrm{M}$, respectively (Table S1 and Figure S3, Supplementary Materials). This suggests an ATP-competitive type of inhibition, which supports our theory of a binding mode within the ATP site of the kinase.

Furthermore, $\mathbf{1 4 b}$ and $\mathbf{2 4}$ were examined for their inhibitory activity on the possible off-target JAK3, as this class of GSK-3 $\beta$ inhibitors is derived from the pan-JAK inhibitor tofacitinib. However, both compounds displayed no significant inhibition of JAK3 in an enzyme-linked immunosorbent assay (Table S2, Supplementary Materials) [25].

In a HLM stability assay, 14b and $\mathbf{2 4}$ were intensively degraded during a timeframe of $120 \mathrm{~min}$ ( $25 \%$ and $8 \%$ remaining parent compound at the endpoint of the experiment, respectively; for details see Tables S3 and S4 as well as Figures S4 and S5, Supplementary Materials). The corresponding unsubstituted piperidines were observed as prominent metabolites.

\subsection{Chemistry}

Our synthetic strategy to access the majority of the herein presented 7-chloro-9H-pyrimido[4,5- $b$ ]indole-based GSK-3 $\beta$ inhibitors featured a convergent approach consisting of the preparation of the key intermediate 4,7-dichloro-9-tosyl-9H-pyrimido[4,5-b]indole (10) as well as the separate synthesis of appropriate alicyclic amine side chains (4a-d) (Scheme 2). Both building blocks were then fused via a nucleophilic aromatic substitution $\left(S_{N} A r\right)$, with successive deprotection and derivatization procedures to afford the final compounds $\mathbf{1 4 a}-\mathbf{n}$ and $\mathbf{1 5 - 1 7}$.

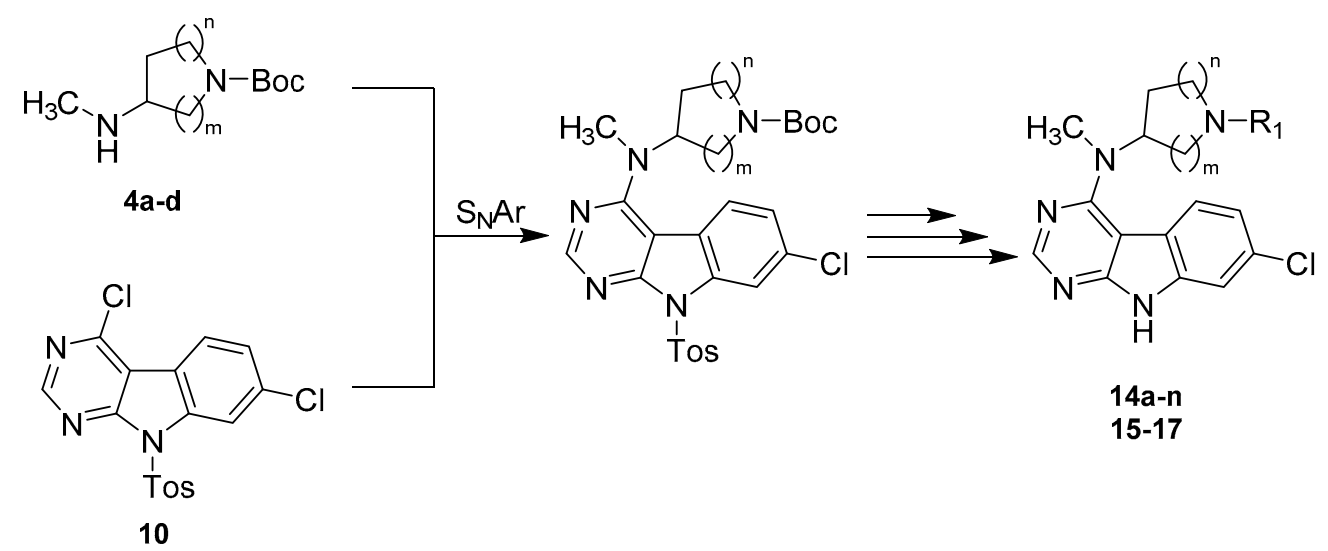

Scheme 2. Synthetic strategy towards 7-chloro-9H-pyrimido[4,5- $b]$ indole-based GSK-3 $\beta$ inhibitors.

The preparation of alicyclic secondary amine side chains $\mathbf{4 a -} \mathbf{d}$ was achieved in two steps via benzyl protected amines 3a-d adapting the strategy of Le Bourdonnec et al. (Scheme 3) [26]. The commercially 
available $N$-Boc protected cyclic ketones $2 \mathbf{a}-\mathbf{d}$ were reductively aminated with $N, N$-benzylmethylamine to give tertiary amines $\mathbf{3 a}-\mathbf{d}$ in moderate to high yields. Sodium triacetoxyborohydride was used as reductive agent facilitating a convenient one-pot procedure. Hydrogenolytic benzyl cleavage with a palladium catalyst gave secondary amines $\mathbf{4 a -} \mathbf{d}$ in nearly quantitative yields.

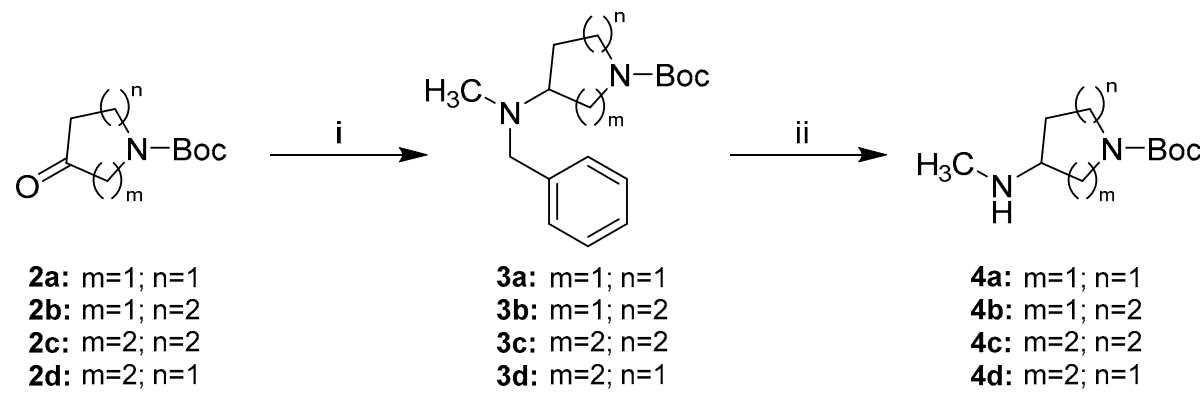

Scheme 3. Synthetic route to alicyclic secondary amine side chains $4 a-d$. Reagents and conditions: (i) N,N-benzylmethylamine, $\mathrm{Na}(\mathrm{OAc})_{3} \mathrm{BH}, \mathrm{AcOH}, \mathrm{DCM}, \mathrm{rt}$, (69-86\%); (ii) $\mathrm{H}_{2}$ (5 bar), $\mathrm{Pd} / \mathrm{C}, \mathrm{MeOH}$ or EtOAc/MeOH 3:2, rt in case of $4 \mathbf{a}-4 \mathbf{c}$ or $\mathrm{Pd} / \mathrm{C}$ and $\mathrm{Pd}(\mathrm{OH})_{2} / \mathrm{C}, \mathrm{MeOH}$, rt in case of $4 \mathbf{d},(96-98 \%)$.

Synthetic literature provides numerous examples for the preparation of $9 \mathrm{H}$-pyrimido[4,5-b]indoles with varying substituents on the non-heteroaromatic ring [27-31]. These typically include four-step procedures starting from appropriately decorated o-halonitrobenzenes, as the substitution pattern of the non-heteroaromatic ring is defined by this starting material. Modifying the protocols published by Reader et al. [31], we prepared key intermediate 4,7-dichloro-9-tosyl-9H-pyrimido[4,5-b]indole (10) starting from 1,4-dichloro-2-nitrobenzene (5) (Scheme 4).

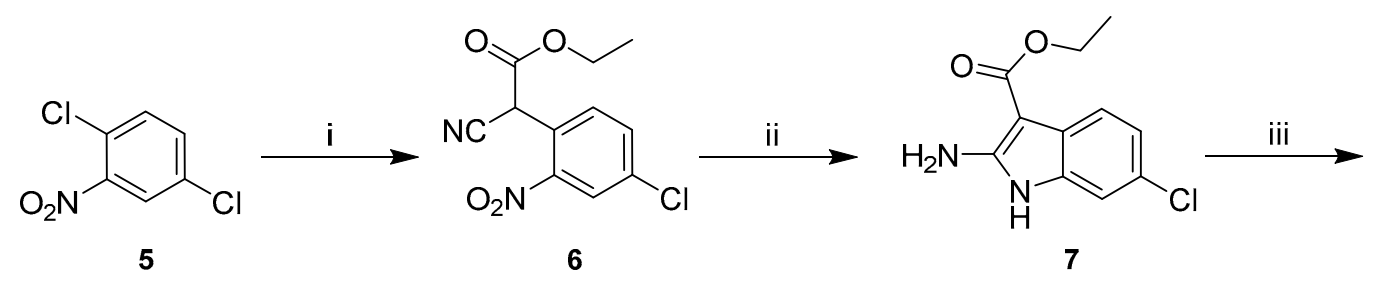<smiles>Cc1ccc2c(c1)[nH]c1nc[nH]c(=O)c12</smiles>

Scheme 4. Synthetic route to 4,7-dichloro-9-tosyl-9H-pyrimido[4,5-b]indole (10). Reagents and conditions: (i) ethyl-2-cyanoacetate, $\mathrm{NaH}, \mathrm{DMF}, 0{ }^{\circ} \mathrm{C}$ to $80{ }^{\circ} \mathrm{C}$, (quant.); (ii) $\mathrm{Zn}, \mathrm{AcOH}, 90{ }^{\circ} \mathrm{C}$, (93\%); (iii) $\mathrm{NH}_{4} \mathrm{HCO}_{2}$, formamide, $160{ }^{\circ} \mathrm{C}$, (86\%); (iv) $\mathrm{POCl}_{3}$, chlorobenzene, $\mathrm{rt}$ to $80{ }^{\circ} \mathrm{C},(51 \%)$; (v) p-toluenesulfonyl chloride, $\mathrm{NaH}, \mathrm{THF}, \mathrm{rt},(99 \%)$.

In the initial step the commercially available 5 underwent an $S_{N} A r$ with the sodium salt of ethyl-2-cyanoacetate, generated in situ with sodium hydride. The resulting intermediate 6 was then subjected to reductive conditions using elemental zinc in acetic acid. The crude product obtained in this cyclization reaction was a mixture of two compounds, which we assume to be the desired 2-aminoindole 7 and the corresponding 1-hydroxy derivative, in analogy to some closely related structures described by Showalter et al. [27]. Treatment of this mixture with formamide under forcing conditions resulted predominantly in 8 , whose carbonyl function was chlorinated with stochiometric amounts of $\mathrm{POCl}_{3}$ in chlorobenzene following the methodology described by Arnott et al. [32].

First attempts of a direct reaction of 9 with the alicyclic amine side chains gave unsatisfactory results, in the form of either prolonged reaction times or significant by-product formation, owing to 
harsh thermal conditions. The installation of a toluenesulfonyl (Tos) protecting group on the indole nitrogen in $\mathbf{1 0}$ significantly enhanced the reactivity of the pyrimidine ring and therefore allowed a clean nucleophilic substitution under relatively mild conditions in DMF and presence of DIPEA (Scheme 5). The sulfonamide protecting group was removed subsequently under basic conditions. A modification of the protocol described by $\mathrm{Xu}$ et al. using a high excess of $\mathrm{K} t \mathrm{BuO}$ (7 eq.) instead of refluxing conditions allowed a fast deprotection at room temperature [33]. This approach gave intermediates 12a-d in satisfying purity and yields (64-77\% over three steps), justifying the synthetic detour associated with the protection of the indole nitrogen. 12a-d were treated with TFA in DCM to convert them into the corresponding secondary amines $\mathbf{1 3 a}-\mathbf{d}$ [34]. These intermediates were then properly decorated by amide coupling, reductive amination [34], nucleophilic substitution [35] or Michael-addition [36] to give final compounds 14a-n and 15-17 listed in Tables 1 and 2, respectively. For the synthesis of 140, lead structure $\mathbf{1 4 b}$ was methylated on its indole nitrogen applying a common procedure.

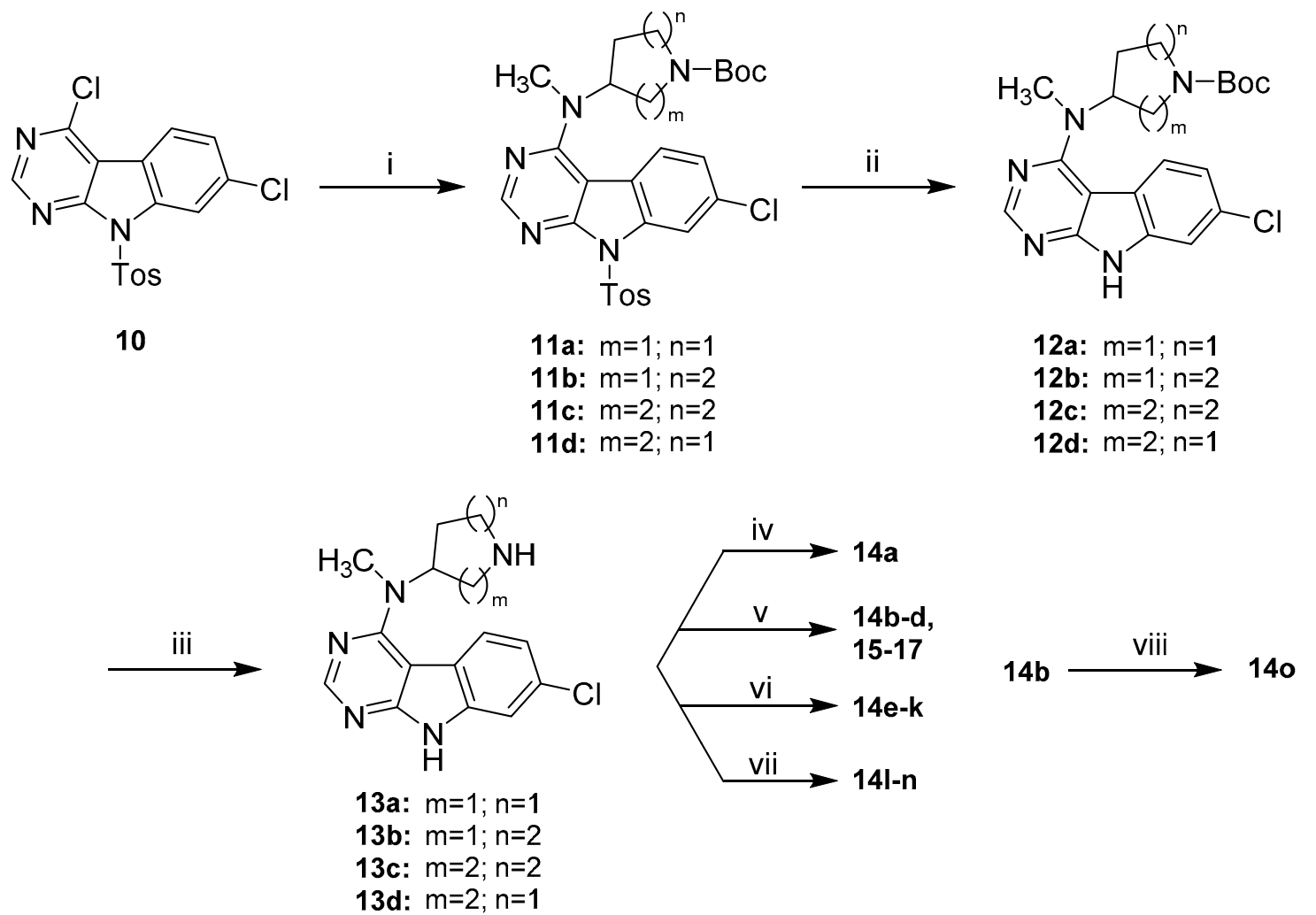

Scheme 5. Synthetic route to final compounds 14a-o listed with their structures in Table 1 and 15-17 listed with their structures in Table 2. Reagents and conditions: (i) $4 \mathbf{a}-\mathbf{d}, \mathrm{DIPEA}, \mathrm{DMF}, 80{ }^{\circ} \mathrm{C},(93 \%$ to quant.); (ii) $\mathrm{KtBuO}, \mathrm{THF}, \mathrm{rt},(65-78 \%)$; (iii) TFA, DCM, rt, (74-99\%); (iv) 13b, cyanoacetic acid, PyBOP, DIPEA, DCM, rt, (59\%); (v) 13a-d, acrylonitrile, MeOH, rt in case of $\mathbf{1 4 b}$ and $\mathbf{1 5 - 1 7}$ or $\mathbf{1 3 b}$, corresponding acrylic acid derivative, $\mathrm{MeOH}$, rt in case of $\mathbf{1 4 c - d},(63-89 \%)$; (vi) 13b, corresponding aldehyde or ketone, $\mathrm{AcOH}, \mathrm{Na}(\mathrm{OAc})_{3} \mathrm{BH}, \mathrm{DCM}, \mathrm{rt},(43-74 \%)$; (vii) 13b, bromoacetonitrile, $\mathrm{Et}_{3} \mathrm{~N}$, $\mathrm{DMF}$, rt in case of $\mathbf{1 4 l}$ or $\mathbf{1 3 b}$, (bromomethyl)cyclopropane, $\mathrm{Et}_{3} \mathrm{~N}, \mathrm{MeCN}, 6{ }^{\circ} \mathrm{C}$ in case of $\mathbf{1 4} \mathbf{m}$ or $\mathbf{1 3 b}$, 3-chloro- $\mathrm{N}, \mathrm{N}$-dimethylpropan-1-amine $\cdot \mathrm{HCl}, \mathrm{Et}_{3} \mathrm{~N}, \mathrm{MeCN}, 90^{\circ} \mathrm{C}$ in case of $\mathbf{1 4 n}$, (39-91\%); (viii) methyl iodide, $\mathrm{NaH}, \mathrm{THF}, \mathrm{rt},(60 \%)$.

For the preparation of the rigidized precursor 22 (Scheme 6) we followed a different synthetic approach compared to the aforementioned secondary amines 4 a-d. The use of 6-azaindole (18) as starting material allowed a selective, high-yielding protection of the pyrrole ring nitrogen with Boc anhydride in THF. The key step of this synthetic route was the following hydrogenation which we achieved under comparably mild conditions using Adam's catalyst in glacial acetic acid giving the free piperidine base 20 [37]. 


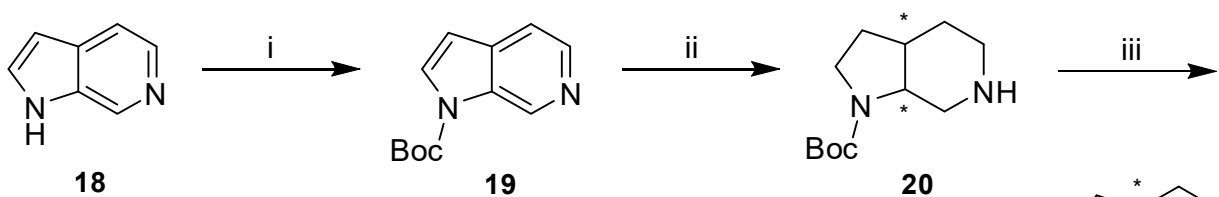

18<smiles>CC(C)C#N</smiles>

21

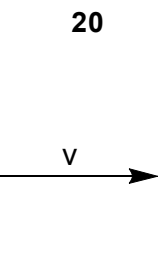<smiles></smiles>

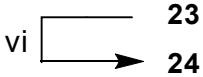

Scheme 6. Synthetic route to final compound 24. Reagents and conditions: (i) $\mathrm{Boc}_{2} \mathrm{O}, \mathrm{THF}, 0{ }^{\circ} \mathrm{C}$ to rt, (92\%); (ii) $\mathrm{H}_{2}$ (5 bar), $\mathrm{PtO}_{2}, \mathrm{AcOH}, \mathrm{rt},(88 \%)$; (iii) acrylonitrile, $\mathrm{MeOH}, \mathrm{rt},(83 \%)$; (iv) $4 \mathrm{~N} \mathrm{HCl}$ in dioxane, $\mathrm{DCM}, \mathrm{rt},(83 \%)$; (v) 10, DIPEA, DMF, $80{ }^{\circ} \mathrm{C}$, (64\%); (vi) $\mathrm{KtBuO}, \mathrm{THF}, \mathrm{rt},(55 \%)$.

In order to decrease the number of subsequent steps the crucial cyanoethyl moiety was directly installed on the piperidine nitrogen rather than an orthogonal protecting group. This conversion was readily achieved by Michael-addition with acrylonitrile in $\mathrm{MeOH}$ (21). Finally, acidic conditions were applied to cleave the protecting carbamate yielding 22 [38], which was reacted with 10 under similar $\mathrm{S}_{\mathrm{N}} \mathrm{Ar}$ conditions with subsequent basic detosylation to afford final compound $\mathbf{2 4}$.

In order to define the stereochemistry at the two stereocenters of the octahydro- $1 H$-pyrrolo[2,3-c]pyridine ring, which were generated during the hydrogenation of Boc-protected azaindole 19, single crystal analysis of $\mathbf{2 4}$ was performed (for details, see Table S5, Supplementary Materials). As expected, $\mathrm{X}$-ray data confirmed that solely a mixture of the $(3 \mathrm{a} R, 7 \mathrm{a} S)$ and $(3 \mathrm{a} S, 7 \mathrm{aR})$ enantiomers of $\mathbf{2 4}$ was obtained (Figure 4$)$.

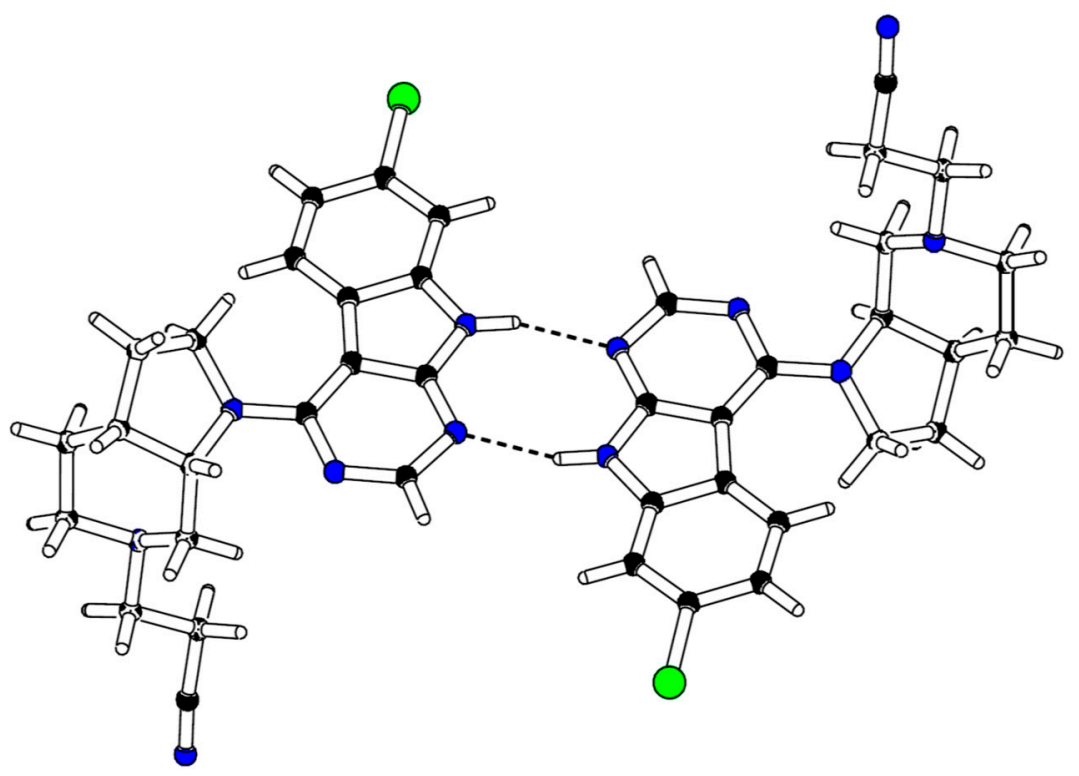

Figure 4. X-ray crystal structure of compound 24.

\section{Conclusions}

Starting from the micromolar GSK-3 $\beta$ screen hit 1, we prepared a series of tofacitinib-derived 7-chloro-9H-pyrimido-[4,5- $b$ ]indole-based compounds. We characterized these compounds in their biological activity in an ADP Glo GSK-3 $\beta$ assay. A switch from amides to tertiary amines proved beneficial for the binding affinity regarding the substituent on the piperidine nitrogen. Moreover, a 
cyanoethyl substituent revealed to be an essential structural feature within this series. We examined the role of the nitrile group in detail and assume that it undergoes crucial hydrogen bonding interactions. We derived a putative binding mode for the most potent inhibitors $\mathbf{1 4 b}$ and $\mathbf{2 4}$ from $1 \mu$ s molecular dynamics simulations. Most importantly, these inhibitors displayed no significant inhibition of the off-target JAK3. However, we observed a lack of metabolic stability in our HLM experiments, which is currently addressed in further optimization studies regarding this novel class of GSK- $3 \beta$ inhibitors.

\section{Materials and Methods}

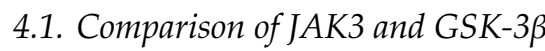

The location of JAK3 and GSK3 $\beta$ in the phylogenetic tree of the human kinome was visualized by KinMap [39]. The sequence alignment was conducted to annotated kinase domains of the Uniprot entries P52333 (JAK3) and P49841 (GSK3B) with Clustal Omega (1.2.4) [40-42].

\subsection{Molecular Modelling}

All the modelling was conducted with Maestro Small-Molecule Drug Discovery Suite 2019-1 (Schrödinger, LLC, New York, NY, USA). The figures and the supplementary movies were prepared with PyMOL 2.2.3 (Schrödinger, LLC).

\subsection{1. $\mathrm{pK}_{\mathrm{a}}$ Calculations}

We used the Jaguar $\mathrm{pK}_{\mathrm{a}}$ module (Schrödinger, LLC) for the $\mathrm{pK}_{\mathrm{a}}$ predictions [43-45]. The calculations were conducted with default settings, except the conformational search step was omitted, as for the input conformation we used the lowest energy structure obtained from QM Conformer \& Tautomer Predictor tool (Schrödinger, LLC). In brief, the QM Conformer \& Tautomer Predictor workflow is the following. First, the proton donor and acceptor atoms are identified, and protons are redistributed among these to form a list of tautomers (protons can also be added to or subtracted from the input molecule). The generated tautomers were next ranked by their semiempirical PM3 heat of formation, and the high-energy tautomers were then discarded. For the surviving tautomers, a set of conformers were generated with MacroModel and the high-energy structures were eliminated by their semiempirical PM3 heat of formation. Subsequently, DFT geometry optimizations were performed on the surviving structures, using the B3LYP-D3/LACVP ${ }^{* *}$ level of theory. Finally, the structures were ranked using single-point energies at the M06-2X/cc-pVTZ(-f) calculated at the optimal geometries from the previous step.

\subsubsection{Simulations}

For the simulations, we used the GSK-3 $\beta$ crystal structure PDB ID: 4PTC [17]. First, the structure (protein-co-crystallized ligand) was prepared by Protein Preparation Wizard [46] (default settings) using OPLS3e force field [24]. Next, the co-crystallized ligand was replaced by the compound 14b or 24, using the QM Conformer \& Tautomer Predictor (for details see 4.2.1) output conformation of the compounds (second lowest energy structure for 14b, Boltzmann population: $20.0 \%$; lowest energy structure for 24, Boltzmann population: 15.6\%; lowest energy structure for 24 ( $3 \mathrm{a} R, 7 \mathrm{a} S)$, Boltzmann population: $13.0 \%$ ). The MD simulations were conducted with Desmond [47] using OPLS3e force field [24], except the charges derived from the QM Conformer \& Tautomer Predictor were applied for the ligands. The systems were solvated in a cubic box (edges $13 \AA$ from the protein) and neutralized with counterions $\left(\mathrm{Cl}^{-}\right)$with $0.15 \mathrm{M} \mathrm{KCl}$ salt. The water was described with TIP3P water model [48]. The final systems consisted of 67,285 (14b) and 71,836 (24, both enantiomers) atoms. Prior to the $1000 \mathrm{~ns}$ production simulations, the default relaxation protocol of Desmond was conducted. The final simulations were conducted in NPT ensemble ( $310 \mathrm{~K}$, thermostat: Nosé-Hoover chain; 1.01325 bar, barostat: Martyna-Tobias-Klein) with the default timestep of 2 fs and cut-off radius of $9.0 \AA$ for Coulombic interactions. 


\subsection{Chemistry}

\subsubsection{General Information}

All solvents and reagents were commercially obtained and used without additional purification. High performance liquid chromatography (HPLC) was performed on an Hewlett Packard HP1090 series II HPLC system (Hewlett-Packard, Palo Alto, CA, USA) or an Agilent 1100 series HPLC system (Agilent, Santa Clara, CA, USA) equipped with a Phenomenex Luna $5 \mu \mathrm{m}$ C8(2) $100 \AA$ RP column $(150 \times 4.6 \mathrm{~mm})$ (Phenomenex, Torrance, CA, USA) and a diode array detector detecting at $230 \mathrm{~nm}$ and $254 \mathrm{~nm}$. The method consisted of elution using mobile phase $\mathrm{A}(\mathrm{MeOH})$ and mobile phase $\mathrm{B}$ (aqueous $0.01 \mathrm{M} \mathrm{KH}_{2} \mathrm{PO}_{4}$ buffer, $\mathrm{pH} 2.3$ ) in a flow of $1.5 \mathrm{~mL} / \mathrm{min}$ and the gradient as follows: mobile phase $\mathrm{A}$ $40 \%$ to $85 \%$ during $8 \mathrm{~min}$, mobile phase A $85 \%$ constant for $5 \mathrm{~min}$, mobile phase A $85 \%$ to $40 \%$ during $1 \mathrm{~min}$, mobile phase A $40 \%$ constant for $2 \mathrm{~min}$; complete run time $16 \mathrm{~min}$; injection volume $5 \mu \mathrm{L}$. Purity of final compounds was determined at $254 \mathrm{~nm}$. Gas chromatography-mass spectrometry (GC-MS) was performed on a Hewlett-Packard HP 6890 Series GC System equipped with an HP 5973 mass selective detector (electron impact ionization) (Hewlett-Packard, Palo Alto, CA, USA). Helium 6.0 was used as carrier gas with a flow of $1.2 \mathrm{~mL} / \mathrm{min}$. In method $A$ a Zebron ZB-5 column $(30 \mathrm{~m} \times 0.25 \mathrm{~mm}$; $0.25 \mu \mathrm{m}$ film thickness) (Phenomenex, Torrance, CA, USA) was used with the following temperature gradient: hold $160{ }^{\circ} \mathrm{C}$ for $1 \mathrm{~min}$, from $160{ }^{\circ} \mathrm{C}$ to $240{ }^{\circ} \mathrm{C}$ during $8 \mathrm{~min}$, hold $240{ }^{\circ} \mathrm{C}$ for $3 \mathrm{~min}$, from $240{ }^{\circ} \mathrm{C}$ to $270{ }^{\circ} \mathrm{C}$ during $3 \mathrm{~min}$, hold $270{ }^{\circ} \mathrm{C}$ for $3 \mathrm{~min}$, from $270{ }^{\circ} \mathrm{C}$ to $300{ }^{\circ} \mathrm{C}$ during $3 \mathrm{~min}$, hold $300^{\circ} \mathrm{C}$ for $12 \mathrm{~min}$; complete run time $33 \mathrm{~min}$. In method $\mathrm{B}$ an Agilent J\&W DB- $5 \mathrm{~ms}(30 \mathrm{~m} \times 0.25 \mathrm{~mm}$; $0.25 \mu \mathrm{m}$ film thickness) (Agilent, Santa Clara, CA, USA) was used with the following temperature gradient: hold $100{ }^{\circ} \mathrm{C}$ for $5 \mathrm{~min}$, from $100{ }^{\circ} \mathrm{C}$ to $320^{\circ} \mathrm{C}$ during $22 \mathrm{~min}$, hold $320{ }^{\circ} \mathrm{C}$ for $5 \mathrm{~min}$; complete run time $32 \mathrm{~min}$. Electrospray ionization mass spectrometry (ESI-MS) was performed on an Advion expression ${ }^{\mathrm{s}}$ CMS TLC-ESI-MS coupling system (Advion, Ithaca, NY, USA) operating in ESI+ mode (capillary temperature $250{ }^{\circ} \mathrm{C}$, capillary voltage $180 \mathrm{~V}$, source gas temperature $250{ }^{\circ} \mathrm{C}$, ESI voltage $3500 \mathrm{~V}$ ) and ESI-mode (capillary temperature $250^{\circ} \mathrm{C}$, capillary voltage $180 \mathrm{~V}$, source gas temperature $250^{\circ} \mathrm{C}$, ESI voltage $2500 \mathrm{~V}$ ), elution with $\mathrm{MeOH}$. Flash column chromatography was performed on an Interchim puriflash 430 or XS 420 (Interchim, Montluçon, France) on Grace Davison Discovery Sciences Davisil Chromatographic Silica Media LC60A (20-45 $\mu \mathrm{m}$ ) (Grace Davison Discovery Sciences, MD, USA) or Interchim puriflash prepacked silica columns (SIHP-JP, $30 \mu \mathrm{m}$ ) (Interchim, Montluçon, France) and Merck Geduran Si60 63-200 $\mu \mathrm{m}$ silica gel (Merck, Darmstadt, Germany) for pre-columns. Mobile phases are described in the detailed procedures. Nuclear magnetic resonance (NMR) analysis was performed on 200, 300, and $400 \mathrm{MHz}$ Bruker Avance spectrometers (Bruker, Billerica, MA, USA). Spectra were calibrated to residual peaks of utilized solvents, chemical shifts are reported in parts per million (ppm) relative to tetramethylsilane $(\delta=0)$. Compounds with amide substituents (Boc protected intermediates and compounds 1 and 14a) often displayed mixtures of amide bond rotamers in their NMR spectra. Thin layer chromatography (TLC) was performed on silica gel coated aluminum sheets (Merck TLC Silica gel $F_{254}$, Merck, Darmstadt, Germany or Macherey-Nagel Alugram Sil G/UV 254 , Macherey-Nagel, Düren, Germany) with visualization under UV light at $254 \mathrm{~nm}$ or by ninhydrin stain.

\subsubsection{General Procedures}

General Procedure A for the Preparation of Intermediates 3a-d by Reductive Amination

The corresponding cyclic ketone (2a-d) (1 eq.) was dissolved in dry DCM. Glacial AcOH (1.1-1.15 eq.) and $N, N$-benzylmethylamine (1.1-1.25 eq.) were added, followed by portion-wise addition of $\mathrm{Na}(\mathrm{OAc})_{3} \mathrm{BH}$ (1.5-1.6 eq.). The mixture was stirred at $\mathrm{rt}$, under $\mathrm{N}_{2}$ atmosphere and over $\mathrm{Na}_{2} \mathrm{SO}_{4}(0.5-1 \mathrm{~g})$ overnight. In case of incomplete consumption of the ketone, additional amine and reductive agent were added to the mixture. After complete conversion, saturated $\mathrm{NaHCO}_{3}$ solution was added and phases were separated. The aqueous layer was extracted thrice with DCM. Combined 
organic layers were dried over $\mathrm{Na}_{2} \mathrm{SO}_{4}$ and concentrated under reduced pressure. The residue was purified by flash column chromatography.

General Procedure B for the Preparation of Intermediates 11a- $d$ by $S_{N} \mathrm{Ar}$

The appropriate secondary amine (4a-d) (1.25-1.4 eq.) and DIPEA (3 eq.) were added to a suspension of 10 (1 eq.) in dry DMF. The mixture was stirred at $70-80{ }^{\circ} \mathrm{C}$ overnight and poured into ice-cold water after completion. Saturated $\mathrm{NH}_{4} \mathrm{Cl}$ solution was added and the formed precipitate filtered, washed with cold water and dried over $\mathrm{P}_{2} \mathrm{O}_{5}$ in vacuo.

General Procedure $C$ for the Preparation of Intermediates 12a- $\mathbf{d}$ by Deprotection of Tosyl Protecting Group

The corresponding intermediate (11a-d) (1 eq.) was dissolved in THF (dry or HPLC grade) and $\mathrm{K} t \mathrm{BuO}$ (7 eq.) was added. The mixture was stirred at rt and under $\mathrm{N}_{2}$ atmosphere for $0.5 \mathrm{~h}$ to $2 \mathrm{~h}$. Saturated $\mathrm{NH}_{4} \mathrm{Cl}$ solution was added and the aqueous phase extracted three to four times with EtOAc. Combined organic layers were dried over $\mathrm{Na}_{2} \mathrm{SO}_{4}$. Volatiles were removed under reduced pressure and the residue purified by flash column chromatography.

General Procedure D for the Preparation of Intermediates 13a- $\mathbf{d}$ by Deprotection of Boc Protecting Group

The appropriate Boc protected amine (12a-d) was dissolved or suspended in dry DCM and stirred. Subsequently trifluoroacetic acid (TFA) was added resulting in a $17 \%(V / V)$ solution which was stirred at $\mathrm{rt}$ for $0.5 \mathrm{~h}$ to $1.5 \mathrm{~h}$. Volatiles were removed under reduced pressure and the highly acidic residue neutralized by addition of saturated $\mathrm{NaHCO}_{3}$ solution $(30 \mathrm{~mL})$. The high polarity of products required repetitive extraction with EtOAc and addition of $\mathrm{MeOH}$ to improve solubility. Combined organic layers were washed thrice with saturated $\mathrm{NaHCO}_{3}$ solution and dried over $\mathrm{Na}_{2} \mathrm{SO}_{4}$. Volatiles were removed under reduced pressure and the residue purified by flash column chromatography or directly used in the next step.

General Procedure E for the Preparation of Final Compounds $\mathbf{1 4} \mathbf{e}-\mathbf{k}$ by Reductive Amination

Intermediate 13b (1 eq.), glacial $\mathrm{AcOH}$ (2 eq.) and the corresponding aldehyde or ketone (1.2-40 eq.) were stirred in dry $\mathrm{DCM}$. $\mathrm{Na}(\mathrm{OAc})_{3} \mathrm{BH}\left(1.5-2.0\right.$ eq.) was added and the reaction stirred at rt, under $\mathrm{N}_{2}$ atmosphere and over some $\mathrm{Na}_{2} \mathrm{SO}_{4}(\sim 50 \mathrm{mg})$ for $2 \mathrm{~h}$ to $6 \mathrm{~h}$. When reaction control by HPLC indicated sufficient conversion, the mixture was diluted with DCM, washed four times with saturated $\mathrm{NaHCO}_{3}$ solution, dried over $\mathrm{Na}_{2} \mathrm{SO}_{4}$ and concentrated under reduced pressure. The residue was purified by flash column chromatography.

\subsubsection{Detailed Procedures}

\section{Preparation of 1}

3-((3R,4R)-3-((7-Chloro-9H-pyrimido[4,5-b]indol-4-yl)(methyl)amino)-4-methylpiperidin-1-yl)-3oxopropanenitrile (1). 4,7-Dichloro-9H-pyrimido[4,5-b]indole (9) $(50.0 \mathrm{mg}, 0.21 \mathrm{mmol})$ and 3-((3R,4R)-4-methyl-3-(methylamino)piperidin-1-yl)-3-oxopropanenitrile hydrochloride [49] (48.7 mg, $0.21 \mathrm{mmol}$ ) were suspended in a mixture of dry dioxane $(1 \mathrm{~mL})$ and dry DMF $(0.1 \mathrm{~mL})$. DIPEA $(67.9 \mathrm{mg}, 0.53 \mathrm{mmol})$ was added and the mixture stirred under microwave irradiation $\left(120^{\circ} \mathrm{C}, 130 \mathrm{~W}\right)$ in a sealed tube for $26 \mathrm{~h}$. Volatiles were removed under reduced pressure. Purification of the residue by flash column chromatography $\left(\mathrm{SiO}_{2}\right.$, 1.EtOAc: $i \mathrm{PrOH}$ 8:1, 2.DCM:MeOH 95:5) gave $24 \mathrm{mg}$ of a light brown solid (29\% yield); NMR shows a 3:1 mixture of amide bond rotamers, ${ }^{1} \mathrm{H}-\mathrm{NMR}(400 \mathrm{MHz}$, acetone- $\left.d_{6}\right) \delta 11.30(\mathrm{~s}, 1 \mathrm{H}), 8.55-8.38(\mathrm{~m}, 1 \mathrm{H}), 7.81(\mathrm{~d}, J=8.5 \mathrm{~Hz}, 1 \mathrm{H}), 7.62(\mathrm{~s}, 1 \mathrm{H}), 7.33(\mathrm{~d}, J=8.4$ $\mathrm{Hz}, 1 \mathrm{H}), 4.85-4.74(\mathrm{~m}, 0.75 \mathrm{H}), 4.27-4.17(\mathrm{~m}, 0.25 \mathrm{H}), 4.11-3.64(\mathrm{~m}, 6 \mathrm{H}), 3.19(\mathrm{~s}, 2.25 \mathrm{H}), 3.05(\mathrm{~s}, 0.75 \mathrm{H})$, 2.51-2.31 (m, 1H), 2.01-1.79 (m, 2H), $1.24(\mathrm{~d}, J=6.8 \mathrm{~Hz}, 0.75 \mathrm{H}), 1.15(\mathrm{~d}, J=6.9 \mathrm{~Hz}, 2.25 \mathrm{H}) ;{ }^{13} \mathrm{C}-\mathrm{NMR}$ 
$\left(101 \mathrm{MHz}\right.$, acetone- $\left.d_{6}\right) \delta 164.5,164.0,161.0,158.8,155.3,138.7,131.4,124.5,122.0,119.6,116.0,112.2$,

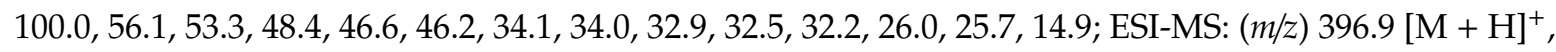
$418.9[\mathrm{M}+\mathrm{Na}]^{+}, 394.9[\mathrm{M}-\mathrm{H}]^{-} ; \mathrm{HPLC}: \mathrm{t}_{\mathrm{r}}=7.201 \mathrm{~min}(100.0 \%$ purity).

Detailed Procedures for the Preparation of Intermediates 3a-d

tert-Butyl-3-(benzyl(methyl)amino)pyrrolidine-1-carboxylate (3a). 3a was prepared from N-Boc-pyrrolidin-3-one (2a) $(1.5 \mathrm{~g}, 8.10 \mathrm{mmol}), \mathrm{N}, \mathrm{N}$-benzylmethylamine $(1.1 \mathrm{~g}, 8.91 \mathrm{mmol})$, glacial $\mathrm{AcOH}(534.9 \mathrm{mg}, 8.91 \mathrm{mmol})$ and $\mathrm{Na}(\mathrm{OAc})_{3} \mathrm{BH}(2.6 \mathrm{~g}, 12.15 \mathrm{mmol})$ in dry DCM $(17 \mathrm{~mL})$ according to general procedure A. Purification by flash column chromatography $\left(\mathrm{SiO}_{2}, \mathrm{n}\right.$-hexane:EtOAc 3:1) gave $1.8 \mathrm{~g}$ of a yellow oil $\left(76 \%\right.$ yield); ${ }^{1} \mathrm{H}-\mathrm{NMR}\left(300 \mathrm{MHz}, \mathrm{CDCl}_{3}\right) \delta 7.38-7.22\left(\mathrm{~m}, 5 \mathrm{H}\right.$, overlap with $\mathrm{CHCl}_{3}$ signal), 3.79-3.46 (m, 4H), 3.36-3.15 (m, 2H), 3.11-2.94 (m, 1H), $2.16(\mathrm{~s}, 3 \mathrm{H}), 2.14-2.05(\mathrm{~m}, 1 \mathrm{H}), 1.98-1.79$ $(\mathrm{m}, 1 \mathrm{H}), 1.48(\mathrm{~s}, 9 \mathrm{H}) ;{ }^{13} \mathrm{C}-\mathrm{NMR}\left(75 \mathrm{MHz} \mathrm{CDCl}_{3}\right) \delta 154.6,138.7,138.6,129.2,129.0,128.4,127.2,79.3$, 64.0, 63.2, 60.5, 50.0, 49.6, 45.2, 44.8, 39.8, 30.1, 29.1, 28.6; GC-MS method A: $\mathrm{t}_{\mathrm{r}}=8.792 \mathrm{~min},(\mathrm{~m} / \mathrm{z}) 290$ [M].

tert-Butyl-3-(benzyl(methyl)amino)piperidine-1-carboxylate $\quad(3 \mathbf{b}) . \quad 3 \mathbf{b}$ was prepared from $N$-Boc-piperidin-3-one (2b) (2.5 g, $12.55 \mathrm{mmol}), N, N$-benzylmethylamine $(2.0 \mathrm{~g}, 16.31 \mathrm{mmol})$, glacial acetic acid (904.1 mg, $15.06 \mathrm{mmol})$ and $\mathrm{Na}(\mathrm{OAc})_{3} \mathrm{BH}(4.3 \mathrm{~g}, 20.08 \mathrm{mmol})$ in dry DCM (30 mL) according to general procedure A. After stirring overnight reaction control indicated incomplete conversion, therefore a second portion of $N, N$-benzylmethylamine $(494.1 \mathrm{mg}, 4.08 \mathrm{mmol})$ and $\mathrm{Na}(\mathrm{OAc}){ }_{3} \mathrm{BH}(1.1 \mathrm{~g}$, $5.02 \mathrm{mmol}$ ) was added and stirring continued for $1 \mathrm{~h}$. Purification by flash column chromatography $\left(\mathrm{SiO}_{2}\right.$, petroleum ether:EtOAc 3:1) gave $2.6 \mathrm{~g}$ of a yellow oil $(69 \%$ yield $) ;{ }^{1} \mathrm{H}-\mathrm{NMR}\left(300 \mathrm{MHz}, \mathrm{CDCl}_{3}\right) \delta$ 7.32-7.07 (m, 5H, overlap with $\mathrm{CHCl}_{3}$ signal), 4.35-3.78 (m, 2H), $3.59(\mathrm{~d}, J=13.5 \mathrm{~Hz}, 1 \mathrm{H}), 3.51(\mathrm{~d}, J=$ $13.4 \mathrm{~Hz}, 1 \mathrm{H}), 2.74-2.49$ (m, 2H), 2.46-2.31 (m, 1H), $2.15(\mathrm{~s}, 3 \mathrm{H}), 1.96-1.82(\mathrm{~m}, 1 \mathrm{H}), 1.70-1.57(\mathrm{~m}, 1 \mathrm{H})$, $1.48-1.29(\mathrm{~m}, 11 \mathrm{H}) ;{ }^{13} \mathrm{C}-\mathrm{NMR}\left(75 \mathrm{MHz} \mathrm{CDCl}_{3}\right) \delta 155.0,139.7,128.8,128.3,126.9,79.4,59.4,58.4,46.2$ (br), 44.4 (br), 38.0, 28.5, 27.6 (br), 24.7 (br).

tert-Butyl-4-(benzyl(methyl)amino)azepane-1-carboxylate $\quad(3 c) . \quad 3 c \quad$ was prepared from $N$-Boc-hexahydro-1H-azepin-4-one (2c) (2.25 g, $10.55 \mathrm{mmol}), N, N$-benzylmethylamine (1.5 g, $12.66 \mathrm{mmol})$, glacial $\mathrm{AcOH}(696.9 \mathrm{mg}, 11.61 \mathrm{mmol})$ and $\mathrm{Na}(\mathrm{OAc})_{3} \mathrm{BH}(3.4 \mathrm{~g}, 15.83 \mathrm{mmol})$ in dry DCM (25 mL) according to general procedure A. After stirring overnight reaction control indicated incomplete conversion, therefore a second portion of $N, N$-benzylmethylamine $(639.2 \mathrm{mg}, 5.27 \mathrm{mmol})$ and $\mathrm{Na}(\mathrm{OAc})_{3} \mathrm{BH}(1.1 \mathrm{~g}, 5.27 \mathrm{mmol})$ was added and stirring continued for $1 \mathrm{~d}$. Purification by flash column chromatography $\left(\mathrm{SiO}_{2}\right.$, n-hexane:EtOAc 3:1) gave $2.7 \mathrm{~g}$ of a yellow oil (81\% yield); ${ }^{1} \mathrm{H}-\mathrm{NMR}$ $\left(300 \mathrm{MHz}_{\mathrm{CDCl}}\right) \delta$ 7.36-7.20 (m, 5H, overlap with $\mathrm{CHCl}_{3}$ signal), 3.66-3.39 (m, 4H), 3.32-3.17 (m, 2H), 2.67-2.56 (m, 1H), 2.21-2.16 (m, 3H), 2.10-1.80 (m, 3H), 1.78-1.41 (m, 12H); ${ }^{13} \mathrm{C}-\mathrm{NMR}\left(75 \mathrm{MHz}, \mathrm{CDCl}_{3}\right)$ $\delta$ 155.6, 140.0, 140.0, 128.7, 128.3, 126.9, 126.9, 79.2, 63.2, 63.1, 57.8, 57.7, 46.8, 46.4, 44.3, 44.0, 37.6, 30.3, $29.9,29.8,28.6,25.9$.

tert-Butyl-4-(benzyl(methyl)amino)piperidine-1-carboxylate $\quad(\mathbf{3 d}) . \quad 3 \mathbf{d}$ was prepared from $N$-Boc-piperidin-4-one (2d) (2.75 g, $13.80 \mathrm{mmol}), \mathrm{N}, \mathrm{N}$-benzylmethylamine $(1.8 \mathrm{~g}, 15.18 \mathrm{mmol})$, glacial $\mathrm{AcOH}(911.7 \mathrm{mg}, 15.18 \mathrm{mmol})$ and $\mathrm{Na}(\mathrm{OAc})_{3} \mathrm{BH}(4.4 \mathrm{~g}, 20.70 \mathrm{mmol})$ in dry DCM $(30 \mathrm{~mL})$ according to general procedure A. The reaction mixture was stirred over molecular sieves instead of $\mathrm{Na}_{2} \mathrm{SO}_{4}$, which was separated by filtration before stopping the reaction with saturated $\mathrm{NaHCO}_{3}$. Purification by flash column chromatography $\left(\mathrm{SiO}_{2}\right.$, petroleum ether:EtOAc:3.5N NH 3 in $\left.\mathrm{MeOH} 25: 73: 2\right)$ gave 3.6 $\mathrm{g}$ of a white solid $(86 \% \text { yield })^{1} \mathrm{H}-\mathrm{NMR}\left(200 \mathrm{MHz}, \mathrm{CDCl}_{3}\right) \delta 7.37-7.17\left(\mathrm{~m}, 5 \mathrm{H}\right.$, overlap with $\mathrm{CHCl}_{3}$ signal), 4.28-4.04 (m, 2H), $3.59(\mathrm{~s}, 2 \mathrm{H}), 2.80-2.50(\mathrm{~m}, 3 \mathrm{H}), 2.21(\mathrm{~s}, 3 \mathrm{H}), 1.90-1.73(\mathrm{~m}, 2 \mathrm{H}), 1.62-1.43(\mathrm{~m}$, $11 \mathrm{H}) ;{ }^{13} \mathrm{C}-\mathrm{NMR}\left(50 \mathrm{MHz}, \mathrm{CDCl}_{3}\right) \delta 154.9,139.5,128.9,128.4,127.1,79.6,60.9,58.1,43.6,37.7,28.6,28.0$; GC-MS method $A: \mathrm{t}_{\mathrm{r}}=9.663 \mathrm{~min},(\mathrm{~m} / \mathrm{z}) 304[\mathrm{M}]$.

Detailed Procedures for the Preparation of Intermediates $4 \mathbf{a}-\mathbf{d}$

tert-Butyl-3-(methylamino)pyrrolidine-1-carboxylate (4a). 3a (1.6 g, $5.51 \mathrm{mmol})$ was dissolved in HPLC grade $\mathrm{MeOH}(30 \mathrm{~mL})$ and $\mathrm{Pd} / \mathrm{C} 10 \%(\mathrm{~m} / \mathrm{m})(532.0 \mathrm{mg})$ was added. The suspension was stirred in a 
reactor charged with 5 bar of $\mathrm{H}_{2}$ pressure at $\mathrm{rt}$ for $4 \mathrm{~h}$ and then filtered over a pad of celite rinsing with fresh solvent. The filtrate was concentrated under reduced pressure to give $1.1 \mathrm{~g}$ of a green oil (96\% crude yield), which was used in the next step without further purification; ${ }^{1} \mathrm{H}-\mathrm{NMR}\left(400 \mathrm{MHz}, \mathrm{CDCl}_{3}\right)$ 反 3.48-3.19 (m, 3H), 3.17-2.93 (m, 2H), 2.33 (s, 3H), 2.00-1.88 (m, 1H), 1.67-1.54 (m, 1H), 1.38-1.33 (m, 9H), 1.30 (br s, 1H); ${ }^{13} \mathrm{C}-\mathrm{NMR}\left(101 \mathrm{MHz}, \mathrm{CDCl}_{3}\right) \delta 154.6,79.0,59.5,58.7,51.6,51.1,44.3,44.0,34.7,31.7$, 31.0, 28.5; GC-MS method $A: \mathrm{t}_{\mathrm{r}}=3.039 \mathrm{~min},(\mathrm{~m} / \mathrm{z}) 200[\mathrm{M}]$.

tert-Butyl-3-(methylamino)piperidine-1-carboxylate (4b). $3 b(2.2 \mathrm{~g}, 7.16 \mathrm{mmol})$ was dissolved in a solvent mixture of EtOAc $(27 \mathrm{~mL})$ and $\mathrm{MeOH}(18 \mathrm{~mL}) . \mathrm{Pd} / \mathrm{C} 10 \%(\mathrm{~m} / \mathrm{m})(727.0 \mathrm{mg})$ was added and the mixture stirred in a reactor charged with 5 bar of $\mathrm{H}_{2}$ pressure at $\mathrm{rt}$ for $3 \mathrm{~h}$. The mixture was filtered over a pad of celite rinsing with fresh solvent. The filtrate was concentrated under reduced pressure to give $1.5 \mathrm{~g}$ of a green oil (96\% crude yield), which was used in the next step without further purification; ${ }^{1} \mathrm{H}-\mathrm{NMR}\left(400 \mathrm{MHz} \mathrm{CDCl}_{3}\right) \delta$ 4.18-3.67 (m, 2H), 2.99-2.51 (m, 2H), 2.49-2.37 (m, 4H), 1.95-1.85 (m, $1 \mathrm{H}), 1.70-1.60(\mathrm{~m}, 1 \mathrm{H}), 1.49-1.37(\mathrm{~m}, 10 \mathrm{H}), 1.35-1.21(\mathrm{~m}, 2 \mathrm{H}) ;{ }^{13} \mathrm{C}-\mathrm{NMR}\left(101 \mathrm{MHz}, \mathrm{CDCl}_{3}\right) \delta$ 155.0, 79.5, 55.6, 48.8 (br), 44.3 (br), 33.9, 31.3, 28.6, 23.6 (br). GC-MS method B: $\mathrm{t}_{\mathrm{r}}=11.729 \mathrm{~min},(\mathrm{~m} / \mathrm{z}) 214$ [M].

tert-Butyl-4-(methylamino)azepane-1-carboxylate (4c). 3c $(662.0 \mathrm{mg}, 2.08 \mathrm{mmol})$ was dissolved in a solvent mixture of EtOAc $(9 \mathrm{~mL})$ and $\mathrm{MeOH}(6 \mathrm{~mL}) . \mathrm{Pd} / \mathrm{C} 10 \%(\mathrm{~m} / \mathrm{m})(220.7 \mathrm{mg})$ was added and the mixture stirred in a reactor charged with 5 bar of $\mathrm{H}_{2}$ pressure at $\mathrm{rt}$ for $3 \mathrm{~h}$. The mixture was filtered over a pad of celite rinsing with fresh solvent. The filtrate was concentrated under reduced pressure to give $463 \mathrm{mg}$ of a green oil (98\% crude yield), which was used in the next step without further purification; ${ }^{1} \mathrm{H}-\mathrm{NMR}\left(400 \mathrm{MHz}, \mathrm{CDCl}_{3}\right) \delta$ 3.54-3.36 (m, 2H), 3.36-3.09 (m, 2H), 2.51-2.41 (m, 1H), $2.36(\mathrm{~s}, 3 \mathrm{H})$, 1.97-1.87 (m, 1H), 1.87-1.72 (m, 2H), 1.59-1.31 (m, 13H); ${ }^{3} \mathrm{C}-\mathrm{NMR}\left(101 \mathrm{MHz}, \mathrm{CDCl}_{3}\right) \delta 155.6,79.2,60.2$, $59.8,46.6,46.0,43.3,42.8,34.8,34.5,34.2,33.2,32.5,28.6,24.8,24.4$. GC-MS method B: $\mathrm{t}_{\mathrm{r}}=13.406 \mathrm{~min}$, $(\mathrm{m} / \mathrm{z}) 228[\mathrm{M}]$.

tert-Butyl-4-(methylamino)piperidine-1-carboxylate $(4 \mathrm{~d}) .3 \mathrm{~d}$ (5.7 $\mathrm{g}, 18.72 \mathrm{mmol})$ was dissolved in $\mathrm{MeOH}(150 \mathrm{~mL}) . \mathrm{Pd} / \mathrm{C} 10 \%(\mathrm{~m} / \mathrm{m})(600 \mathrm{mg})$ and $\mathrm{Pd}(\mathrm{OH})_{2} / \mathrm{C} 20 \%(\mathrm{~m} / \mathrm{m})(300 \mathrm{mg})$ were added and the mixture stirred in a reactor charged with 5 bar of $\mathrm{H}_{2}$ pressure at rt overnight. The mixture was filtered over a pad of celite rinsing with fresh solvent. The filtrate was concentrated under reduced pressure to give $3.9 \mathrm{~g}$ of a green oil (97\% crude yield), which was used in the next step without further purification; 1H-NMR (200 MHz, $\left.\mathrm{CDCl}_{3}\right) \delta$ 4.17-3.83 (m, 2H), 2.88-2.65 (m, 2H), 2.55-2.42 (m, 1H), 2.40 (s, 3H), 1.92-1.74 (m, 2H), $1.42(\mathrm{~s}, 9 \mathrm{H}), 1.33-1.04(\mathrm{~m}, 2 \mathrm{H}) ;{ }^{13} \mathrm{C}-\mathrm{NMR}\left(50 \mathrm{MHz}, \mathrm{CDCl}_{3}\right) \delta 155.0,79.5,56.8,42.6$ (br), 33.5, 32.2, 28.5; GC-MS method $A: \mathrm{t}_{\mathrm{r}}=3.499 \mathrm{~min},(\mathrm{~m} / \mathrm{z}) 214$ [M].

Detailed Procedures for the Preparation of 4,7-dichloro-9-tosyl-9H-pyrimido[4,5- $b$ ]indole (10)

Ethyl-2-(4-chloro-2-nitrophenyl)-2-cyanoacetate (6). A solution of ethyl-2-cyanoacetate (12.4 g, $109.38 \mathrm{mmol})$ in dry DMF (10 mL) was drop-added to a stirring, ice-cooled suspension of $\mathrm{NaH}$ ( $4.4 \mathrm{~g}$ of a $60 \%$ dispersion in mineral oil, $109.38 \mathrm{mmol})$ in dry DMF $(20 \mathrm{~mL})$. After complete addition, the dropping funnel was purged with additional dry DMF $(5 \mathrm{~mL})$ and ice-cooling was removed. After stirring at $\mathrm{rt}$ for $0.5 \mathrm{~h}$, a solution of 1,4-dichloro-2-nitrobenzene (5) $(10.0 \mathrm{~g}, 52.08 \mathrm{mmol})$ in dry DMF (10 $\mathrm{mL}$ ) was drop-added. The stirring mixture was subsequently heated to $80^{\circ} \mathrm{C}$ for $0.5 \mathrm{~h}$, when reaction control via HPLC indicated complete conversion. The mixture was left to cool to rt and acidified with $10 \% \mathrm{HCl}_{(\mathrm{aq})}(50 \mathrm{~mL})$. EtOAc $(100 \mathrm{~mL})$ was added, phases were separated and the aqueous layer extracted with additional EtOAc $(3 \times 30 \mathrm{~mL})$. Combined organic layers were washed with saturated $\mathrm{NaCl}$ solution $(5 \times 50 \mathrm{~mL})$ and dried over $\mathrm{Na}_{2} \mathrm{SO}_{4}$. The mixture was concentrated under reduced pressure and the liquid residue treated with ice-cold water and stirred with ice-cooling. The resulting yellow precipitate was triturated with the ice-cold water, filtered washing with ice-cold water and dried over $\mathrm{P}_{2} \mathrm{O}_{5}$ in vacuo. $14.5 \mathrm{~g}$ of a yellow solid ( $>100 \%$ crude yield) that may contain traces of excessive ethyl-2-cyanoacetate, but was used in the next step without further purification; ${ }^{1} \mathrm{H}-\mathrm{NMR}$ $\left(200 \mathrm{MHz}, \mathrm{DMSO}-d_{6}\right) \delta 8.35(\mathrm{~d}, J=2.0 \mathrm{~Hz}, 1 \mathrm{H}), 8.02(\mathrm{dd}, J=8.2,2.1 \mathrm{~Hz}, 1 \mathrm{H}), 7.78(\mathrm{~d}, J=8.2 \mathrm{~Hz}, 1 \mathrm{H})$, $6.27(\mathrm{~s}, 1 \mathrm{H}), 4.22(\mathrm{q}, J=7.1 \mathrm{~Hz}, 2 \mathrm{H}), 1.19(\mathrm{t}, J=7.1 \mathrm{~Hz}, 3 \mathrm{H}) ;{ }^{13} \mathrm{C}-\mathrm{NMR}\left(50 \mathrm{MHz}, \mathrm{DMSO}-d_{6}\right) \delta 163.7$, 
147.4, 135.2, 134.9, 134.6, 126.0, 124.5, 115.0, 63.1, 40.7, 13.8; ESI-MS: $(\mathrm{m} / z) 266.9[\mathrm{M}-\mathrm{H}]^{-}$; HPLC: $\mathrm{t}_{\mathrm{r}}=$ $6.655 \mathrm{~min}$.

Ethyl-2-amino-6-chloro-1H-indole-3-carboxylate (7). 6 (7.0 g, $26.06 \mathrm{mmol})$ was dissolved in glacial $\mathrm{AcOH}(60 \mathrm{~mL})$. The solution was stirred at $85^{\circ} \mathrm{C}$ and Zinc dust $(20.4 \mathrm{~g}, 312.72 \mathrm{mmol})$ was added in ten portions. The suspension was stirred at $85^{\circ} \mathrm{C}$ for $75 \mathrm{~min}$ when reaction control via HPLC indicated complete consumption of the starting material. After cooling to $\mathrm{rt}$, $\mathrm{Zn}$ dust was filtered off rinsing with $\mathrm{AcOH}$ (or EtOAc, alternatively) and the filtrate was concentrated under reduced pressure to leave a liquid residue. Careful addition of saturated $\mathrm{NaHCO}_{3}$ solution neutralized residual $\mathrm{AcOH}$ resulting in a precipitate which was filtered off, washed with water and dried over $\mathrm{P}_{2} \mathrm{O}_{5}$ in vacuo. $5.8 \mathrm{~g}$ of a red-brown solid (93\% crude yield), which was used in the next step without further purification. A small batch was purified by flash column chromatography $\left(\mathrm{SiO}_{2}, \mathrm{DCM} / \mathrm{MeOH}\right.$ 97.5:2.5) for analytical purposes. ${ }^{1} \mathrm{H}-\mathrm{NMR}$ shows a mixture of products, which are assumed to be the title compound and the corresponding 1-hydroxyindole [27]; HPLC: $\mathrm{t}_{\mathrm{r}}=8.042 \mathrm{~min}$.

7-Chloro-3,9-dihydro-4H-pyrimido[4,5-b]indol-4-one (8). 7 (5.7 g, $23.88 \mathrm{mmol})$ and $\mathrm{NH}_{4} \mathrm{HCO}_{2}(1.7 \mathrm{~g}$, $27.46 \mathrm{mmol}$ ) were suspended in formamide $(50 \mathrm{~mL})$ and stirred at $160^{\circ} \mathrm{C}$ for $28 \mathrm{~h}$ with reflux cooling when reaction control via HPLC indicated nearly full consumption of the starting material. After cooling to rt the mixture was poured into ice-cold water resulting in a precipitate which was filtered, washed thoroughly with ice-cold water and dried over $\mathrm{P}_{2} \mathrm{O}_{5}$ in vacuo. $4.5 \mathrm{~g}$ of a green-brown solid (86\% crude yield), which was used in the next step without further purification; ${ }^{1} \mathrm{H}-\mathrm{NMR}(200 \mathrm{MHz}$, DMSO- $\left.d_{6}\right) \delta 12.32(\mathrm{br} \mathrm{s}, 2 \mathrm{H}), 8.15(\mathrm{~s}, 1 \mathrm{H}), 7.95(\mathrm{~d}, J=8.5 \mathrm{~Hz}, 1 \mathrm{H}), 7.48(\mathrm{~d}, J=1.4 \mathrm{~Hz}, 1 \mathrm{H}), 7.25(\mathrm{dd}, J=$ 8.5, $1.5 \mathrm{~Hz}, 1 \mathrm{H}) ;{ }^{13} \mathrm{C}-\mathrm{NMR}\left(50 \mathrm{MHz}\right.$, DMSO- $\left.d_{6}\right) \delta 158.0,154.3,148.0,136.0,128.4,121.8,121.4,120.9$, 111.4, 100.0; ESI-MS: $(\mathrm{m} / \mathrm{z}) 217.9[\mathrm{M}-\mathrm{H}]^{-}$; HPLC: $\mathrm{t}_{\mathrm{r}}=5.489 \mathrm{~min}$.

4,7-Dichloro-9H-pyrimido[4,5-b]indole (9). 8 (4.5 g, $20.44 \mathrm{mmol}$ ) was suspended in chlorobenzene (30 $\mathrm{mL})$ and DIPEA ( $4.0 \mathrm{~g}, 30.66 \mathrm{mmol})$ was added. The mixture was stirred at $\mathrm{rt}$ and under $\mathrm{N}_{2}$ atmosphere when $\mathrm{POCl}_{3}(4.4 \mathrm{~g}, 28.62 \mathrm{mmol})$ was added carefully dropwise. After stirring at $\mathrm{rt}$ for $1 \mathrm{~h}$, the mixture was heated to $80^{\circ} \mathrm{C}$ for additional $4.5 \mathrm{~h}$ with reflux cooling when HPLC indicated complete consumption of the starting material. The mixture was left to cool down and dropped carefully into stirring water $(300 \mathrm{~mL})$ at rt resulting in a brown precipitate. Saturated $\mathrm{NaHCO}_{3}$ solution was added carefully and the suspension left to stir overnight for neutralization. The precipitate was filtered, washed with water and dried over $\mathrm{P}_{2} \mathrm{O}_{5}$ in vacuo. $4.2 \mathrm{~g}$ of a brown solid (87\% crude yield), which was purified by the following recrystallization procedure: $2 \mathrm{~g}$ of crude 4,7-dichloro- $9 \mathrm{H}$-pyrimido[4,5-b]indole were suspended in boiling toluene $(650 \mathrm{~mL})$ and stirred for $0.5 \mathrm{~h}$. The hot suspension was filtered rinsing the brown filter cake with fresh hot toluene. The filtrate was concentrated under reduced pressure resulting in precipitation of the product. The suspension was cooled and subsequently the precipitate was filtered, washed with cold toluene and dried under reduced pressure giving $1.2 \mathrm{~g}$ of a yellow solid (59\% recrystallization yield, $51 \%$ total yield); ${ }^{1} \mathrm{H}-\mathrm{NMR}\left(200 \mathrm{MHz}, \mathrm{DMSO}-d_{6}\right) \delta 12.85(\mathrm{~s}, 1 \mathrm{H}), 8.76(\mathrm{~s}$, $1 \mathrm{H}), 8.14(\mathrm{~d}, J=8.5 \mathrm{~Hz}, 1 \mathrm{H}), 7.57(\mathrm{~d}, J=1.9 \mathrm{~Hz}, 1 \mathrm{H}), 7.37(\mathrm{dd}, J=8.5,1.9 \mathrm{~Hz}, 1 \mathrm{H}) ;{ }^{13} \mathrm{C}-\mathrm{NMR}(50 \mathrm{MHz}$, DMSO- $\left.d_{6}\right) \delta 156.3,154.2,151.3,139.1,132.7,123.6,121.9,116.5,112.0,110.7$; ESI-MS: $(\mathrm{m} / z) 235.7$ [M $\mathrm{H}^{-} ;$; HPLC: $\mathrm{t}_{\mathrm{r}}=8.590 \mathrm{~min}$.

4,7-Dichloro-9-tosyl-9H-pyrimido[4,5-b]indole (10). $\mathrm{NaH}(151.2 \mathrm{mg}$ of a $60 \%$ dispersion in mineral oil, $3.78 \mathrm{mmol}$ ) was added in three portions to a stirring suspension of 4,7-dichloro-9H-pyrimido[4,5-b]indole (9) $(600.0 \mathrm{mg}$, $2.52 \mathrm{mmol})$ in dry THF $(20 \mathrm{~mL})$. p-Toluenesulfonyl chloride $(576.6 \mathrm{mg}, 3.02 \mathrm{mmol}$ ) was added after $20 \mathrm{~min}$ and stirring continued for another $0.5 \mathrm{~h}$ at rt and under $\mathrm{N}_{2}$ atmosphere when TLC indicated complete consumption of the starting material. The mixture was poured into ice-cold water and saturated $\mathrm{NH}_{4} \mathrm{Cl}$ solution $(60 \mathrm{~mL})$ was added. The precipitate was filtered, washed with cold water and dried over $\mathrm{P}_{2} \mathrm{O}_{5}$ in vacuo. $982 \mathrm{mg}$ of a yellow solid ( $99 \%$ crude yield), which was directly used in the next step without further purification; ESI-MS: $(\mathrm{m} / \mathrm{z}) 390.0[\mathrm{M}-\mathrm{H}]^{-}$. 
Detailed Procedures for the Preparation of Intermediates 11a-d

tert-Butyl-3-((7-chloro-9-tosyl-9H-pyrimido[4,5-b]indol-4-yl)(methyl)amino)pyrrolidine-1-carboxyla-te (11a). 11a was prepared from 10 (1.0 g, $2.55 \mathrm{mmol}), 4 a(638.4 \mathrm{mg}, 3.19 \mathrm{mmol})$ and DIPEA (988.8 mg, $7.65 \mathrm{mmol})$ in dry DMF (25 mL) according to general procedure B. $1.4 \mathrm{~g}$ of a beige solid (>100\% crude yield), which was used in the next step without further purification. A small batch was purified by flash column chromatography $\left(\mathrm{SiO}_{2}, \mathrm{DCM}: \mathrm{MeOH}\right.$ 97.5:2.5) for analytical purposes; ${ }^{1} \mathrm{H}-\mathrm{NMR}(300$ $\left.\mathrm{MHz} \mathrm{CDCl}_{3}\right) \delta 8.64(\mathrm{~s}, 1 \mathrm{H}), 8.54(\mathrm{~d}, J=1.8 \mathrm{~Hz}, 1 \mathrm{H}), 8.10(\mathrm{~d}, J=8.1 \mathrm{~Hz}, 2 \mathrm{H}), 7.63(\mathrm{~d}, J=8.5 \mathrm{~Hz}, 1 \mathrm{H})$, $7.40(\mathrm{dd}, J=8.5,1.9 \mathrm{~Hz}, 1 \mathrm{H}), 7.27\left(\mathrm{~d}, 2 \mathrm{H}\right.$, overlap with $\mathrm{CHCl}_{3}$ signal), 4.93-4.74 (m, 1H), 3.94-3.75 $(\mathrm{m}, 1 \mathrm{H}), 3.71-3.53(\mathrm{~m}, 1 \mathrm{H}), 3.48-3.29(\mathrm{~m}, 2 \mathrm{H}), 3.10(\mathrm{~s}, 3 \mathrm{H}), 2.37(\mathrm{~s}, 3 \mathrm{H}), 2.33-2.06(\mathrm{~m}, 2 \mathrm{H}), 1.46(\mathrm{~s}, 9 \mathrm{H})$; ${ }^{13} \mathrm{C}-\mathrm{NMR}\left(50 \mathrm{MHz}, \mathrm{CDCl}_{3}\right) \delta 161.2,157.2,154.5,154.3,145.8,136.2,135.3,132.9,129.8,128.1,124.5$, 123.3, 119.9, 114.7, 102.0, 79.6, 58.0, 57.4, 47.8, 44.7, 44.3, 35.2, 28.7, 28.6, 28.0, 21.7; ESI-MS: $(\mathrm{m} / \mathrm{z}) 578.1$ $[\mathrm{M}+\mathrm{Na}]^{+}, 554.3[\mathrm{M}-\mathrm{H}]^{-} ; \mathrm{HPLC}: \mathrm{t}_{\mathrm{r}}=11.123 \mathrm{~min}$.

tert-Butyl-3-((7-chloro-9-tosyl-9H-pyrimido[4,5-b]indol-4-yl)(methyl)amino)piperidine-1-carboxylate (11b). 11b was prepared from 10 (430.0 mg, $1.10 \mathrm{mmol}), 4 \mathbf{b}(328.9 \mathrm{mg}, 1.54 \mathrm{mmol})$ and DIPEA (425.1 $\mathrm{mg}, 3.29 \mathrm{mmol})$ in dry DMF $(12 \mathrm{~mL})$ according to general procedure B. $580 \mathrm{mg}$ of a beige solid (93\% crude yield), which was used in the next step without further purification. A small batch was purified by flash column chromatography $\left(\mathrm{SiO}_{2}, \mathrm{DCM}: \mathrm{MeOH}\right.$ 97.5:2.5) for analytical purposes; ${ }^{1} \mathrm{H}-\mathrm{NMR}(300$ $\left.\mathrm{MHz} \mathrm{CDCl}_{3}\right) \delta 8.60(\mathrm{~s}, 1 \mathrm{H}), 8.52(\mathrm{~d}, J=1.9 \mathrm{~Hz}, 1 \mathrm{H}), 8.09(\mathrm{~d}, J=8.4 \mathrm{~Hz}, 2 \mathrm{H}), 7.60(\mathrm{~d}, J=8.1 \mathrm{~Hz}, 1 \mathrm{H})$, $7.38(\mathrm{dd}, J=8.5,1.9 \mathrm{~Hz}, 1 \mathrm{H}), 7.25\left(\mathrm{~d}, J=8.1 \mathrm{~Hz}, 2 \mathrm{H}\right.$, overlap with $\mathrm{CHCl}_{3}$ signal $), 4.49-3.96(\mathrm{~m}, 3 \mathrm{H}), 3.10$ $(\mathrm{s}, 3 \mathrm{H}), 3.08-2.98(\mathrm{~m}, 1 \mathrm{H}), 2.76-2.61(\mathrm{~m}, 1 \mathrm{H}), 2.35(\mathrm{~s}, 3 \mathrm{H}), 2.00-1.71(\mathrm{~m}, 3 \mathrm{H}), 1.63-1.50(\mathrm{~m}, 1 \mathrm{H}), 1.39(\mathrm{~s}$, 9H); ESI-MS: $(m / z) 569.9[\mathrm{M}+\mathrm{H}]^{+}, 591.9[\mathrm{M}+\mathrm{Na}]^{+}, 568.0[\mathrm{M}-\mathrm{H}]^{-} ; \mathrm{HPLC}: \mathrm{t}_{\mathrm{r}}=11.456 \mathrm{~min}$.

tert-Butyl-4-((7-chloro-9-tosyl-9H-pyrimido[4,5-b]indol-4-yl)(methyl)amino)azepane-1-carboxylate (11c). 11c was prepared from 10 (465.0 mg, $1.19 \mathrm{mmol}), 4 \mathrm{c}(338.4 \mathrm{mg}, 1.48 \mathrm{mmol})$ and DIPEA (459.7 mg, $3.56 \mathrm{mmol})$ in dry DMF (14 mL) according to general procedure B. $682 \mathrm{mg}$ of a beige solid (98\% crude yield), which was used in the next step without further purification. A small batch was purified by flash column chromatography $\left(\mathrm{SiO}_{2}, \mathrm{DCM}: \mathrm{MeOH}\right.$ 97.5:2.5) for analytical purposes; ${ }^{1} \mathrm{H}-\mathrm{NMR}(400$ MHz, DMSO- $\left.d_{6}\right) \delta 8.49(\mathrm{~s}, 1 \mathrm{H}), 8.36(\mathrm{~d}, J=1.9 \mathrm{~Hz}, 1 \mathrm{H}), 8.07-8.01(\mathrm{~m}, 2 \mathrm{H}), 7.79-7.73(\mathrm{~m}, 1 \mathrm{H}), 7.52(\mathrm{dd}, J$ $=8.6,1.6 \mathrm{~Hz}, 1 \mathrm{H}), 7.40(\mathrm{~d}, J=8.2 \mathrm{~Hz}, 2 \mathrm{H}), 4.28-4.18(\mathrm{~m}, 1 \mathrm{H}), 3.49-3.35(\mathrm{~m}, 2 \mathrm{H}), 3.29-3.12(\mathrm{~m}, 2 \mathrm{H}), 3.04$ $(\mathrm{s}, 3 \mathrm{H}), 2.33(\mathrm{~s}, 3 \mathrm{H}), 1.96-1.76(\mathrm{~m}, 5 \mathrm{H}), 1.67-1.53(\mathrm{~m}, 1 \mathrm{H}), 1.36-1.28(\mathrm{~m}, 9 \mathrm{H})$; ESI-MS: $(\mathrm{m} / \mathrm{z}) 606.0[\mathrm{M}+$ $\mathrm{Na}]^{+}, 582.1[\mathrm{M}-\mathrm{H}]^{-}$; HPLC: $\mathrm{t}_{\mathrm{r}}=11.827 \mathrm{~min}$.

tert-Butyl-4-((7-chloro-9-tosyl-9H-pyrimido[4,5-b]indol-4-yl)(methyl)amino)piperidine-1-carboxylate (11d). 11d was prepared from $10(200.0 \mathrm{mg}, 0.51 \mathrm{mmol}), 4 \mathrm{~d}(142.1 \mathrm{mg}, 0.66 \mathrm{mmol})$ and DIPEA (197.7 $\mathrm{mg}, 1.53 \mathrm{mmol})$ in dry DMF $(5.5 \mathrm{~mL})$ according to general procedure B. Beige solid ( $>100 \%$ crude yield), which was used in the next step without further purification. A small batch was purified by flash column chromatography $\left(\mathrm{SiO}_{2}\right.$, petroleum ether:EtOAc gradient elution from 9:1 to 4:6) for analytical purposes; ${ }^{1} \mathrm{H}-\mathrm{NMR}\left(200 \mathrm{MHz}, \mathrm{CDCl}_{3}\right) \delta 8.59(\mathrm{~s}, 1 \mathrm{H}), 8.52(\mathrm{~d}, J=1.8 \mathrm{~Hz}, 1 \mathrm{H}), 8.09(\mathrm{~d}, J=$ $8.3 \mathrm{~Hz}, 2 \mathrm{H}), 7.54(\mathrm{~d}, J=8.6 \mathrm{~Hz}, 1 \mathrm{H}), 7.37(\mathrm{dd}, J=8.5,1.9 \mathrm{~Hz}, 1 \mathrm{H}), 7.26(\mathrm{~d}, J=8.2 \mathrm{~Hz}, 2 \mathrm{H}$, overlap with $\mathrm{CHCl}_{3}$ signal), 4.49-4.33 (m, 1H), 4.33-4.16 (m, 2H), $3.07(\mathrm{~s}, 3 \mathrm{H}), 2.94-2.68(\mathrm{~m}, 2 \mathrm{H}), 2.36(\mathrm{~s}, 3 \mathrm{H})$, 1.92-1.72 (m, 4H), 1.47 (s, 9H); ${ }^{13} \mathrm{C}-\mathrm{NMR}\left(50 \mathrm{MHz}, \mathrm{CDCl}_{3}\right) \delta 160.1,157.4,154.8,154.1,145.8,136.2,135.5$, $132.7,129.8,128.2,124.4,123.1,120.5,114.8,100.8,80.0,56.6,43.4$ (br), 33.4, 29.0, 28.6, 21.8. ESI-MS: $(m / z)$ $592.0[\mathrm{M}+\mathrm{Na}]^{+}, 568.0[\mathrm{M}-\mathrm{H}]^{-} ; \mathrm{HPLC}: \mathrm{t}_{\mathrm{r}}=11.988 \mathrm{~min}$.

\section{Detailed Procedures for the Preparation of Intermediates 12a-d}

tert-Butyl-3-((7-chloro-9H-pyrimido[4,5-b]indol-4-yl)(methyl)amino)pyrrolidine-1-carboxylate (12a). 12a was prepared from 11a $(697.0 \mathrm{mg}, 1.26 \mathrm{mmol})$ and $\mathrm{K} t \mathrm{BuO}(986.1 \mathrm{mg}, 8.79 \mathrm{mmol})$ in dry THF $(40 \mathrm{~mL})$ according to general procedure $\mathrm{C}$ in a reaction time of $1.5 \mathrm{~h}$. Purification by flash column chromatography ( $\mathrm{SiO}_{2}, \mathrm{DCM}: \mathrm{MeOH}$ gradient elution from 97.5:2.5 to 93:7) gave $394 \mathrm{mg}$ of a beige solid (78\% yield); ${ }^{1} \mathrm{H}-\mathrm{NMR}\left(300 \mathrm{MHz}, \mathrm{CDCl}_{3}\right) \delta 11.68$ (br s, 1H), 8.65-8.51 (m, 1H), $7.74(\mathrm{~d}, J=8.6 \mathrm{~Hz}$, 
$1 \mathrm{H}), 7.53(\mathrm{~d}, J=1.8 \mathrm{~Hz}, 1 \mathrm{H}), 7.29\left(\mathrm{dd}, 1 \mathrm{H}\right.$, overlap with $\mathrm{CHCl}_{3}$ signal), 5.23-5.02 $(\mathrm{m}, 1 \mathrm{H}), 3.99-3.80(\mathrm{~m}$, $1 \mathrm{H}), 3.78-3.37(\mathrm{~m}, 3 \mathrm{H}), 3.30(\mathrm{~s}, 3 \mathrm{H}), 2.39-2.14(\mathrm{~m}, 2 \mathrm{H}), 1.49(\mathrm{~s}, 9 \mathrm{H}),{ }^{13} \mathrm{C}-\mathrm{NMR}\left(50 \mathrm{MHz}\right.$, DMSO- $\left.d_{6}\right) \delta$ 160.2, 157.4, 153.7, 153. 6, 137.5, 129.5, 124.0, 120.6, 118.3, 110.9, 98.1, 78.4, 56.8, 56.2, 47.0, 44.4, 44.1, 34.1, 28.2, 27.9, 27.0; ESI-MS: $(\mathrm{m} / \mathrm{z}) 424.2[\mathrm{M}+\mathrm{Na}]^{+}, 400.2[\mathrm{M}-\mathrm{H}]^{-}$; HPLC: $\mathrm{t}_{\mathrm{r}}=9.653 \mathrm{~min}$.

tert-Butyl-3-((7-chloro-9H-pyrimido[4,5-b]indol-4-yl)(methyl)amino)piperidine-1-carboxylate (12b). 12b was prepared from $\mathbf{1 1 b}(580.0 \mathrm{mg}, 1.02 \mathrm{mmol})$ and $\mathrm{KtBuO}(799.1 \mathrm{mg}, 7.12 \mathrm{mmol})$ in dry THF $(32 \mathrm{~mL})$ according to general procedure $\mathrm{C}$ in a reaction time of $1 \mathrm{~h}$. Purification by flash column chromatography $\left(\mathrm{SiO}_{2}, \mathrm{DCM}: \mathrm{MeOH}\right.$ gradient elution from 97.5:2.5 to 93:7) gave $320 \mathrm{mg}$ of a beige solid (76\% yield); ${ }^{1} \mathrm{H}-\mathrm{NMR}\left(200 \mathrm{MHz}, \mathrm{CDCl}_{3}\right) \delta 12.25(\mathrm{br} \mathrm{s}, 1 \mathrm{H}), 8.57(\mathrm{~s}, 1 \mathrm{H}), 7.70(\mathrm{~d}, J=8.6 \mathrm{~Hz}, 1 \mathrm{H}), 7.50(\mathrm{~d}$, $J=1.8 \mathrm{~Hz}, 1 \mathrm{H}), 7.24\left(\mathrm{dd}, 1 \mathrm{H}\right.$, overlap with $\mathrm{CHCl}_{3}$ signal), 4.59-3.95 $(\mathrm{m}, 3 \mathrm{H}), 3.26(\mathrm{~s}, 3 \mathrm{H}), 3.17-2.96(\mathrm{~m}$, $1 \mathrm{H}), 2.84-2.56(\mathrm{~m}, 1 \mathrm{H}), 2.19-1.55(\mathrm{~m}, 4 \mathrm{H}), 1.43(\mathrm{~s}, 9 \mathrm{H}) ;{ }^{13} \mathrm{C}-\mathrm{NMR}\left(50 \mathrm{MHz}, \mathrm{CDCl}_{3}\right) \delta 160.2,157.2,155.0$, 152.5, 137.5, 131.1, 123.7, 121.5, 118.8, 111.6, 98.7, 80.0, 55.2, 46.8, 44.1, 33.4, 28.5, 28.2, 25.0; ESI-MS: $(\mathrm{m} / \mathrm{z})$ $438.0[\mathrm{M}+\mathrm{Na}]^{+}, 413.9[\mathrm{M}-\mathrm{H}]^{-} ;$HPLC: $\mathrm{t}_{\mathrm{r}}=9.001 \mathrm{~min}$.

tert-Butyl-4-((7-chloro-9H-pyrimido[4,5-b]indol-4-yl)(methyl)amino)azepane-1-carboxylate (12c). 12c was prepared from 11c $(682.0 \mathrm{mg}, 1.17 \mathrm{mmol})$ and $\mathrm{KtBuO}(917.0 \mathrm{mg}, 8.17 \mathrm{mmol})$ in dry THF $(40 \mathrm{~mL})$ following general procedure $\mathrm{C}$ in a reaction time of $0.75 \mathrm{~h}$. Purification by flash column chromatography $\left(\mathrm{SiO}_{2}, \mathrm{DCM}: \mathrm{MeOH}\right.$ gradient elution from $97.5: 2.5$ to $\left.93: 7\right)$ gave $392 \mathrm{mg}$ of a beige solid (78\% yield); ${ }^{1} \mathrm{H}-\mathrm{NMR}\left(400 \mathrm{MHz}, \mathrm{CDCl}_{3}\right) \delta 12.43(\mathrm{br} \mathrm{s}, 1 \mathrm{H}), 8.55(\mathrm{~s}, 1 \mathrm{H}), 7.69-7.62(\mathrm{~m}, 1 \mathrm{H}), 7.50-7.45(\mathrm{~m}, 1 \mathrm{H}), 7.25-7.20$ $(\mathrm{m}, 1 \mathrm{H}), 4.64-4.52(\mathrm{~m}, 1 \mathrm{H}), 3.88-3.78(\mathrm{~m}, 0.5 \mathrm{H}), 3.72-3.63(\mathrm{~m}, 0.5 \mathrm{H}), 3.57-3.38(\mathrm{~m}, 2 \mathrm{H}), 3.28-3.15(\mathrm{~m}$, $4 \mathrm{H}), 2.11-1.67(\mathrm{~m}, 6 \mathrm{H}), 1.47(\mathrm{~s}, 9 \mathrm{H}){ }^{13} \mathrm{C}-\mathrm{NMR}\left(101 \mathrm{MHz}, \mathrm{CDCl}_{3}\right) \delta 159.9,157.3,155.7,152.7,137.5,130.9$, 123.5, 121.3, 119.0, 111.6, 98.4, 79.6, 58.9, 58.4, 46.9, 46.0, 43.6, 43.5, 33.1, 32.3, 31.82, 31.79, 31.5, 28.7, 25.43, 25.36; ESI-MS: $(\mathrm{m} / \mathrm{z}) 430.0[\mathrm{M}+\mathrm{H}]^{+}, 452.0[\mathrm{M}+\mathrm{Na}]^{+}, 428.0[\mathrm{M}-\mathrm{H}]^{-}$; HPLC: $\mathrm{t}_{\mathrm{r}}=9.734 \mathrm{~min}$.

tert-Butyl-4-((7-chloro-9H-pyrimido[4,5-b]indol-4-yl)(methyl)amino)piperidine-1-carboxylate (12d). 12d was prepared from $11 \mathrm{~d}(290.8 \mathrm{mg}, 0.51 \mathrm{mmol})$ and $\mathrm{K} t \mathrm{BuO}(400.7 \mathrm{mg}, 3.57 \mathrm{mmol})$ in HPLC grade THF $(32 \mathrm{~mL})$ according to general procedure $\mathrm{C}$ in a reaction time of $2 \mathrm{~h}$. Purification by flash column chromatography $\left(\mathrm{SiO}_{2}, \mathrm{DCM}: \mathrm{MeOH}\right.$ gradient elution from 97.5:2.5 to 93:7) gave $138 \mathrm{mg}$ of an off-white solid (65\% yield); ${ }^{1} \mathrm{H}-\mathrm{NMR}\left(400 \mathrm{MHz}, \mathrm{CDCl}_{3}\right) \delta 12.09(\mathrm{~s}, 1 \mathrm{H}), 8.56(\mathrm{~s}, 1 \mathrm{H}), 7.67(\mathrm{~d}, J=8.6 \mathrm{~Hz}, 1 \mathrm{H}), 7.48$ $(\mathrm{d}, J=1.9 \mathrm{~Hz}, 1 \mathrm{H}), 7.24(\mathrm{dd}, J=8.6,1.9 \mathrm{~Hz}, 1 \mathrm{H}), 4.70-4.58(\mathrm{~m}, 1 \mathrm{H}), 4.46-4.11(\mathrm{~m}, 2 \mathrm{H}), 3.23(\mathrm{~s}, 3 \mathrm{H})$, 2.99-2.75 (m, 2H), 1.96-1.80 (m, 4H), $1.50(\mathrm{~s}, 9 \mathrm{H}) ;{ }^{13} \mathrm{C}-\mathrm{NMR}\left(50 \mathrm{MHz}, \mathrm{CDCl}_{3}\right) \delta$ 160.0, 157.2, 154.9, 152.5, 137.5, 130.9, 123.4, 121.2, 118.9, 111.6, 98.3, 79.9, 55.9, 43.6, 33.2, 29.1, 28.6; ESI-MS: $(m / z) 416.1[\mathrm{M}+\mathrm{H}]^{+}$, $438.1[\mathrm{M}+\mathrm{Na}]^{+}, 414.1[\mathrm{M}-\mathrm{H}]^{-} ;$HPLC: $\mathrm{t}_{\mathrm{r}}=10.236 \mathrm{~min}$.

Detailed Procedures for the Preparation of Intermediates 13a-d

7-Chloro- $N$-methyl- $N$-(pyrrolidin-3-yl)-9H-pyrimido[4,5-b] indol-4-amine (13a). 13a was prepared from 12a $(340.0 \mathrm{mg}, 0.85 \mathrm{mmol})$ and TFA $(1.8 \mathrm{~mL})$ in dry DCM $(9 \mathrm{~mL})$ according to general procedure D. 220 $\mathrm{mg}$ of a beige solid ( $86 \%$ yield), which was used in the next step without further purification; ${ }^{1} \mathrm{H}-\mathrm{NMR}$ $\left(300 \mathrm{MHz}, \mathrm{DMSO}-d_{6}\right) \delta 8.40(\mathrm{~s}, 1 \mathrm{H}), 7.83(\mathrm{~d}, J=8.6 \mathrm{~Hz}, 1 \mathrm{H}), 7.48(\mathrm{~d}, J=2.0 \mathrm{~Hz}, 1 \mathrm{H}), 7.27(\mathrm{dd}, J=8.6$, $2.0 \mathrm{~Hz}, 1 \mathrm{H}), 4.97-4.85(\mathrm{~m}, 1 \mathrm{H}), 3.17(\mathrm{~s}, 3 \mathrm{H}), 3.14-3.07(\mathrm{~m}, 1 \mathrm{H}), 3.00-2.75(\mathrm{~m}, 3 \mathrm{H}), 2.12-1.98(\mathrm{~m}, 1 \mathrm{H})$, $1.94-1.80(\mathrm{~m}, 1 \mathrm{H})$. Both N-H not detected due to hydrogen bonding; ${ }^{13} \mathrm{C}-\mathrm{NMR}\left(75 \mathrm{MHz}\right.$, DMSO- $\left.d_{6}\right) \delta$ 160.1, 157.4, 153.7, 137.4, 129.2, 123.8, 120.4, 118.6, 110.8, 97.6, 58.8, 49.2, 46.4, 33.4, 29.0; ESI-MS: $(\mathrm{m} / \mathrm{z})$ $301.9[\mathrm{M}+\mathrm{H}]^{+}, 299.9[\mathrm{M}-\mathrm{H}]^{-}$, HPLC: $\mathrm{t}_{\mathrm{r}}=3.556 \mathrm{~min}$.

7-Chloro- $\mathrm{N}$-methyl- $\mathrm{N}$-(piperidin-3-yl)-9H-pyrimido[4,5-b]indol-4-amine (13b). 13b was prepared from $\mathbf{1 2 b}(314.0 \mathrm{mg}, 0.76 \mathrm{mmol})$ and TFA $(1.7 \mathrm{~mL})$ in dry DCM $(8.5 \mathrm{~mL})$ according to general procedure $\mathrm{D}$ in a reaction time of $1 \mathrm{~h}$. $236 \mathrm{mg}$ of a beige solid (99\% yield), which was used in the next step without further purification; ${ }^{1} \mathrm{H}-\mathrm{NMR}(300 \mathrm{MHz}, \mathrm{MeOD}) \delta 8.34(\mathrm{~s}, 1 \mathrm{H}), 7.75(\mathrm{~d}, J=8.6 \mathrm{~Hz}, 1 \mathrm{H}), 7.49(\mathrm{~d}, J=$ $1.9 \mathrm{~Hz}, 1 \mathrm{H}), 7.26(\mathrm{dd}, J=8.6,2.0 \mathrm{~Hz}, 1 \mathrm{H}), 4.48(\mathrm{tt}, J=11.2,4.0 \mathrm{~Hz}, 1 \mathrm{H}), 3.25(\mathrm{~s}, 3 \mathrm{H}), 3.17-3.08(\mathrm{~m}, 1 \mathrm{H})$, 3.05-2.96 (m, 1H), 2.96-2.86 (m, 1H), 2.63-2.49 (m, 1H), 2.16-1.85 (m, 3H), 1.78-1.60 (m, 1H); ${ }^{13} \mathrm{C}-\mathrm{NMR}$ 
$\left(50 \mathrm{MHz}, \mathrm{DMSO}-d_{6}\right) \delta 159.6,157.5,153.7,137.4,129.1,123.8,120.4,118.7,110.8,97.1,55.7,48.6,45.5$, 32.7, 28.2, 26.4; ESI-MS: $(\mathrm{m} / \mathrm{z}) 316.0[\mathrm{M}+\mathrm{H}]^{+}, 338.0[\mathrm{M}+\mathrm{Na}]^{+}, 313.9[\mathrm{M}-\mathrm{H}]^{-}$; HPLC: $\mathrm{t}_{\mathrm{r}}=3.815 \mathrm{~min}$.

$N$-(Azepan-4-yl)-7-chloro- $N$-methyl-9H-pyrimido[4,5-b]indol-4-amine (13c). 13c was prepared from 12c $(125.0 \mathrm{mg}, 0.29 \mathrm{mmol})$ and TFA $(1 \mathrm{~mL})$ in dry DCM $(5 \mathrm{~mL})$ according to general procedure D in a reaction time of $1.5 \mathrm{~h}$. Purification by flash column chromatography $\left(\mathrm{SiO}_{2}, \mathrm{DCM}: 2 \mathrm{~N} \mathrm{NH}_{3}\right.$ in $\left.\mathrm{MeOH} 9: 1\right)$ gave $71 \mathrm{mg}$ of a beige solid $\left(74 \%\right.$ yield) ${ }^{1} \mathrm{H}-\mathrm{NMR}\left(400 \mathrm{MHz}, \mathrm{CDCl}_{3}\right) \delta 8.53(\mathrm{~s}, 1 \mathrm{H}), 7.66(\mathrm{~d}, J=8.6 \mathrm{~Hz}$, $1 \mathrm{H}), 7.44(\mathrm{~d}, J=1.6 \mathrm{~Hz}, 1 \mathrm{H}), 7.20(\mathrm{dd}, J=8.6,1.8 \mathrm{~Hz}, 1 \mathrm{H}), 4.75-4.66(\mathrm{~m}, 1 \mathrm{H}), 3.23(\mathrm{~s}, 3 \mathrm{H}), 3.12-2.99(\mathrm{~m}$, 2H), 2.96-2.87 (m, 2H), 2.13-1.96 (m, 4H), 1.95-1.85 (m, 1H), 1.78-1.66 (m, 1H). Both N-H not detected due to hydrogen bonding; ${ }^{13} \mathrm{C}-\mathrm{NMR}\left(101 \mathrm{MHz}, \mathrm{CDCl}_{3}\right) \delta 160.1,157.8,153.1,137.5,130.7,123.5,121.1$, $119.2,111.5,98.5,58.6,48.9,46.1,35.0,32.7,31.6,27.6$; ESI-MS: $(m / z) 329.9[\mathrm{M}+\mathrm{H}]^{+}, 328.0\left[\mathrm{M}-\mathrm{H}^{-}\right.$; HPLC: $\mathrm{t}_{\mathrm{r}}=3.401 \mathrm{~min}$.

7-Chloro-N-methyl-N-(piperidin-4-yl)-9H-pyrimido[4,5-b]indol-4-amine (13d). 13d was prepared from 12d (105.0 $\mathrm{mg}, 0.25 \mathrm{mmol})$ and TFA $(0.6 \mathrm{~mL})$ in dry DCM $(3 \mathrm{~mL})$ according to general procedure D in a reaction time of $1 \mathrm{~h}$. $73 \mathrm{mg}$ of a beige solid (92\% yield) which was used in the next step without further purification; ${ }^{1} \mathrm{H}-\mathrm{NMR}(400 \mathrm{MHz}, \mathrm{MeOD}) \delta 8.34(\mathrm{~s}, 1 \mathrm{H}), 7.73(\mathrm{~d}, J=8.6 \mathrm{~Hz}, 1 \mathrm{H}), 7.50(\mathrm{~d}, J=1.9$ $\mathrm{Hz}, 1 \mathrm{H}), 7.26(\mathrm{dd}, J=8.6,2.0 \mathrm{~Hz}, 1 \mathrm{H}), 4.55-4.46(\mathrm{~m}, 1 \mathrm{H}), 3.23(\mathrm{~s}, 3 \mathrm{H}), 3.21-3.13(\mathrm{~m}, 2 \mathrm{H}), 2.76-2.66(\mathrm{~m}$, $2 \mathrm{H}), 2.02-1.90(\mathrm{~m}, 2 \mathrm{H}), 1.90-1.83(\mathrm{~m}, 2 \mathrm{H})$; ESI-MS: $(\mathrm{m} / \mathrm{z}) 316.0[\mathrm{M}+\mathrm{H}]^{+}, 314.0[\mathrm{M}-\mathrm{H}]^{-} ; \mathrm{HPLC}: \mathrm{t}_{\mathrm{r}}=$ $3.485 \mathrm{~min}$.

\section{Detailed Procedures for the Preparation of Compounds 14a-o}

3-(3-((7-Chloro-9H-pyrimido[4,5-b]indol-4-yl)(methyl)amino)piperidin-1-yl)-3-oxopropanenitrile (14a). Cyanoacetic acid (23.1 mg, $0.27 \mathrm{mmol})$ and PyBOP (141.4 mg, $0.27 \mathrm{mmol}$ ) were dissolved in dry DCM $(5 \mathrm{~mL})$ and stirred at $\mathrm{rt}$ and under $\mathrm{N}_{2}$ atmosphere for $20 \mathrm{~min}$. A suspension of $\mathbf{1 3 b}(71.5 \mathrm{mg}, 0.23 \mathrm{mmol})$ and DIPEA $(87.8 \mathrm{mg}, 0.68 \mathrm{mmol})$ in dry DCM $(5 \mathrm{~mL})$ was added and the mixture stirred at rt and under $\mathrm{N}_{2}$ atmosphere for $1.5 \mathrm{~h}$. The mixture was then diluted with DCM, washed with saturated $\mathrm{NaHCO}_{3}$ solution $(4 \times 15 \mathrm{~mL})$, dried over $\mathrm{Na}_{2} \mathrm{SO}_{4}$ and concentrated under reduced pressure. Purification of the residue by flash column chromatography $\left(\mathrm{SiO}_{2}, 1\right.$. DCM:MeOH gradient elution from 95:5 to 92.5:7.5, 2. DCM:EtOH gradient elution from 96.5:3.5 to 93:7) gave $51 \mathrm{mg}$ of a white solid (59\% yield); NMR shows a 7:3 mixture of amide bond rotamers, ${ }^{1} \mathrm{H}\left(400 \mathrm{MHz}, \mathrm{CDCl}_{3}\right) \delta 12.59$ (br s, $\left.1 \mathrm{H}\right), 8.51-8.30$ $(\mathrm{m}, 1 \mathrm{H}), 7.67-7.48(\mathrm{~m}, 1 \mathrm{H}), 7.41-7.30(\mathrm{~m}, 1 \mathrm{H}), 7.21-7.09(\mathrm{~m}, 1 \mathrm{H}), 4.90-4.78(\mathrm{~m}, 0.3 \mathrm{H}), 4.70-4.58(\mathrm{~m}$, $0.7 \mathrm{H}), 4.45-4.23(\mathrm{~m}, 1 \mathrm{H}), 4.22-4.11(\mathrm{~m}, 0.7 \mathrm{H}), 4.04-3.79(\mathrm{~m}, 1.4 \mathrm{H}), 3.78-3.69(\mathrm{~m}, 0.3 \mathrm{H}), 3.66-3.54(\mathrm{~m}$, 0.6H), 3.30-3.12 (m, 4H), 3.05-2.94 (m, 0.3H), 2.70-2.56 (m, 0.7H), 2.26-1.88 (m, 3H), 1.86-1.64 (m, 1H); ${ }^{13} \mathrm{C}-\mathrm{NMR}\left(101 \mathrm{MHz}, \mathrm{CDCl}_{3}\right) \delta 161.2,160.6,159.8,157.2,156.7,152.5,152.0,137.5,137.4,131.24,131.17$, 123.6, 123.5, 121.5, 121.4, 118.41, 118.35, 114.7, 114.1, 111.7, 111.6, 98.5, 77.4, 55.5, 54.6, 48.2, 46.9, 45.4, 43.5, 34.9, 34.0, 28.7, 27.6, 25.40, 25.37, 25.2, 24.8; ESI-MS: $(m / z) 383.1[\mathrm{M}+\mathrm{H}]^{+}, 405.1[\mathrm{M}+\mathrm{Na}]^{+}, 380.9$ $[\mathrm{M}-\mathrm{H}]^{-} ; \mathrm{HPLC}: \mathrm{t}_{\mathrm{r}}=6.202 \mathrm{~min}(100.0 \%$ purity $)$.

3-(3-((7-Chloro-9H-pyrimido[4,5-b]indol-4-yl)(methyl)amino)piperidin-1-yl)propanenitrile (14b). 13b $(125.0 \mathrm{mg}, 0.40 \mathrm{mmol})$ and acrylonitrile $(46.2 \mathrm{mg}, 0.87 \mathrm{mmol})$ were stirred in dry $\mathrm{MeOH}(35 \mathrm{~mL})$ at $\mathrm{rt}$ and under $\mathrm{N}_{2}$ atmosphere overnight. Volatiles were removed under reduced pressure. Purification of the residue by flash column chromatography $\left(\mathrm{SiO}_{2}, \mathrm{DCM}: \mathrm{MeOH}\right.$ gradient elution from 95.5:4.5 to 93.5:6.5) gave $92 \mathrm{mg}$ of a white solid (63\% yield); ${ }^{1} \mathrm{H}-\mathrm{NMR}\left(400 \mathrm{MHz}, \mathrm{DMSO}-d_{6}\right) \delta 12.22(\mathrm{~s}, 1 \mathrm{H}), 8.40$ $(\mathrm{s}, 1 \mathrm{H}), 7.78(\mathrm{~d}, J=8.6 \mathrm{~Hz}, 1 \mathrm{H}), 7.48(\mathrm{~s}, 1 \mathrm{H}), 7.34(\mathrm{~d}, J=8.4 \mathrm{~Hz}, 1 \mathrm{H}), 4.56-4.33(\mathrm{~m}, 1 \mathrm{H}), 3.14(\mathrm{~s}, 3 \mathrm{H})$, 3.11-3.03 (m, 1H), 2.92-2.81 (m, 1H), 2.78-2.68 (m, 2H), 2.68-2.58 (m, 2H), 2.44-2.32 (m, 1H), 2.02-1.88 $(\mathrm{m}, 1 \mathrm{H}), 1.84-1.63(\mathrm{~m}, 3 \mathrm{H}), 1.59-1.41(\mathrm{~m}, 1 \mathrm{H}) ;{ }^{13} \mathrm{C}-\mathrm{NMR}\left(101 \mathrm{MHz}, \mathrm{DMSO}-d_{6}\right) \delta 159.4,157.4,153.7$, 137.3, 129.1, 123.8, 120.6, 120.0, 118.5, 110.8, 97.0, 55.7, 54.7, 53.0, 52.2, 32.5, 27.2, 24.3, 15.0. ESI-MS: (m/z) $369.1[\mathrm{M}+\mathrm{H}]^{+}, 391.0[\mathrm{M}+\mathrm{Na}]^{+}, 366.9[\mathrm{M}-\mathrm{H}]^{-} ; \mathrm{HPLC}: \mathrm{t}_{\mathrm{r}}=3.695 \min (100.0 \%$ purity).

3-(3-((7-Chloro-9H-pyrimido[4,5-b]indol-4-yl)(methyl)amino)piperidin-1-yl)propanamide (14c). 13b $(65.0 \mathrm{mg}, 0.21 \mathrm{mmol})$ and acrylamide $(16.1 \mathrm{mg}, 0.23 \mathrm{mmol})$ were stirred in dry $\mathrm{MeOH}(11 \mathrm{~mL})$ at $\mathrm{rt}$ and 
under $\mathrm{N}_{2}$ atmosphere overnight. Additional acrylamide $(16.1 \mathrm{mg}, 0.23 \mathrm{mmol})$ was added and stirring at $\mathrm{rt}$ continued for 5 days. Volatiles were removed under reduced pressure. Purification of the residue by flash column chromatography $\left(\mathrm{SiO}_{2}, \mathrm{DCM}: 2 \mathrm{~N} \mathrm{NH}_{3}\right.$ in $\mathrm{MeOH}$ gradient elution from 92:8 to 9:1) gave $65 \mathrm{mg}$ of a white solid (82\% yield); ${ }^{1} \mathrm{H}-\mathrm{NMR}\left(400 \mathrm{MHz}\right.$, DMSO- $\left.d_{6}\right) \delta 12.21(\mathrm{~s}, 1 \mathrm{H}), 8.39(\mathrm{~s}, 1 \mathrm{H}), 7.76$ $(\mathrm{d}, J=8.7 \mathrm{~Hz}, 1 \mathrm{H}), 7.48(\mathrm{~d}, J=2.0 \mathrm{~Hz}, 1 \mathrm{H}), 7.34(\mathrm{br} \mathrm{s}, 1 \mathrm{H}), 7.30(\mathrm{dd}, J=8.6,2.0 \mathrm{~Hz}, 1 \mathrm{H}), 6.78(\mathrm{br} \mathrm{s}, 1 \mathrm{H})$, 4.50-4.34 (m, 1H), $3.15(\mathrm{~s}, 3 \mathrm{H}), 3.05-2.96(\mathrm{~m}, 1 \mathrm{H}), 2.87-2.77(\mathrm{~m}, 1 \mathrm{H}), 2.65-2.52(\mathrm{~m}, 2 \mathrm{H}), 2.35-2.18(\mathrm{~m}$, 3H), 1.96-1.85 (m, 1H), 1.84-1.65 (m, 3H), 1.58-1.42 (m, 1H); ${ }^{13} \mathrm{C}-\mathrm{NMR}\left(101 \mathrm{MHz}\right.$, DMSO- $\left.d_{6}\right) \delta 173.2$, 159.4, 157.4, 153.7, 137.3, 129.1, 123.8, 120.5, 118.5, 110.8, 97.0, 55.9, 54.8, 54.2, 52.7, 33.0, 32.6, 27.4, 24.4; ESI-MS: $(\mathrm{m} / \mathrm{z}) 387.4[\mathrm{M}+\mathrm{H}]^{+}, 409.4[\mathrm{M}+\mathrm{Na}]^{+}, 385.3[\mathrm{M}-\mathrm{H}]^{-} ; \mathrm{HPLC}: \mathrm{t}_{\mathrm{r}}=3.872 \mathrm{~min}(100.0 \%$ purity).

Methyl-3-(3-((7-chloro-9H-pyrimido[4,5-b]indol-4-yl)(methyl)amino)piperidin-1-yl)propanoate (14d). $13 \mathbf{b}(65.0 \mathrm{mg}, 0.21 \mathrm{mmol})$ and methyl acrylate $(19.5 \mathrm{mg}, 0.23 \mathrm{mmol})$ were stirred in dry $\mathrm{MeOH}(11 \mathrm{~mL})$ at $\mathrm{rt}$ and under $\mathrm{N}_{2}$ atmosphere for $3 \mathrm{~h}$. Additional methyl acrylate $(4.4 \mathrm{mg}, 0.05 \mathrm{mmol})$ was added and stirring at rt continued for $1 \mathrm{~h}$. Volatiles were removed under reduced pressure. Purification of the residue by flash column chromatography $\left(\mathrm{SiO}_{2}, \mathrm{DCM}: \mathrm{MeOH}\right.$ gradient elution from 96:4 to 92:8) gave $74 \mathrm{mg}$ of a beige solid $\left(89 \%\right.$ yield); ${ }^{1} \mathrm{H}-\mathrm{NMR}\left(400 \mathrm{MHz}\right.$, DMSO- $\left.d_{6}\right) \delta 12.21(\mathrm{~s}, 1 \mathrm{H}), 8.39(\mathrm{~s}, 1 \mathrm{H}), 7.75(\mathrm{~d}, J$ $=8.7 \mathrm{~Hz}, 1 \mathrm{H}), 7.47(\mathrm{~d}, J=2.0 \mathrm{~Hz}, 1 \mathrm{H}), 7.28(\mathrm{dd}, J=8.6,2.0 \mathrm{~Hz}, 1 \mathrm{H}), 4.45-4.34(\mathrm{~m}, 1 \mathrm{H}), 3.55(\mathrm{~s}, 3 \mathrm{H}), 3.14$ (s, 3H), 3.00-2.92 (m, 1H), 2.84-2.75 (m, 1H), $2.62(\mathrm{t}, J=6.9 \mathrm{~Hz}, 2 \mathrm{H}), 2.53-2.46(\mathrm{~m}, 2 \mathrm{H}$, overlap with DMSO- $d_{5}$ signal), $2.36-2.26(\mathrm{~m}, 1 \mathrm{H}), 1.95-1.85(\mathrm{~m}, 1 \mathrm{H}), 1.83-1.65(\mathrm{~m}, 3 \mathrm{H}), 1.55-1.41(\mathrm{~m}, 1 \mathrm{H}) ;{ }^{13} \mathrm{C}-\mathrm{NMR}$ $\left(101 \mathrm{MHz}\right.$, DMSO- $\left.d_{6}\right) \delta 172.4,159.4,157.4,153.7,137.3,129.1,123.8,120.4,118.5,110.8,97.0,55.9,54.8$, 53.3, 52.5, 51.1, 32.6, 31.6, 27.3, 24.4; ESI-MS: $(\mathrm{m} / \mathrm{z}) 402.5\left[\mathrm{M}+\mathrm{H}^{+}, 424.6[\mathrm{M}+\mathrm{Na}]^{+}, 400.3[\mathrm{M}-\mathrm{H}]^{-}\right.$; HPLC: $\mathrm{t}_{\mathrm{r}}=4.363 \mathrm{~min}(100.0 \%$ purity).

7-Chloro- $N$-methyl- $N$-(1-propylpiperidin-3-yl)-9H-pyrimido[4,5-b]indol-4-amine (14e). 14e was prepared from $13 \mathbf{b}(65.0 \mathrm{mg}, 0.21 \mathrm{mmol})$, propionaldehyde $(17.9 \mathrm{mg}, 0.31 \mathrm{mmol})$, glacial $\mathrm{AcOH}$ $(24.7 \mathrm{mg}, 0.41 \mathrm{mmol})$ and $\mathrm{Na}(\mathrm{OAc})_{3} \mathrm{BH}(87.2 \mathrm{mg}, 0.41 \mathrm{mmol})$ in dry DCM $(10 \mathrm{~mL})$ according to general procedure $\mathrm{E}$ in a reaction time of $2 \mathrm{~h}$. Purification by flash column chromatography $\left(\mathrm{SiO}_{2}, 1\right.$. DCM:2N $\mathrm{NH}_{3}$ in $\mathrm{MeOH}$ gradient elution from 95:5 to 92:8, 2. DCM:2N NH $\mathrm{N}_{3}$ in $\mathrm{MeOH}$ gradient elution from 94:6 to 91.5:8.5) gave $46 \mathrm{mg}$ of a white solid (62\% yield); ${ }^{1} \mathrm{H}-\mathrm{NMR}\left(400 \mathrm{MHz}, \mathrm{DMSO}-d_{6}\right) \delta 2.21(\mathrm{~s}, 1 \mathrm{H})$, $8.39(\mathrm{~s}, 1 \mathrm{H}), 7.78(\mathrm{~d}, J=8.7 \mathrm{~Hz}, 1 \mathrm{H}), 7.47(\mathrm{~d}, J=2.0 \mathrm{~Hz}, 1 \mathrm{H}), 7.23(\mathrm{dd}, J=8.6,2.0 \mathrm{~Hz}, 1 \mathrm{H}), 4.48-4.37(\mathrm{~m}$, $1 \mathrm{H}), 3.14(\mathrm{~s}, 3 \mathrm{H}), 3.00-2.91(\mathrm{~m}, 1 \mathrm{H}), 2.84-2.76(\mathrm{~m}, 1 \mathrm{H}), 2.33-2.17(\mathrm{~m}, 3 \mathrm{H}), 1.87-1.66(\mathrm{~m}, 4 \mathrm{H}), 1.58-1.39$ $(\mathrm{m}, 3 \mathrm{H}), 0.84(\mathrm{t}, J=7.3 \mathrm{~Hz}, 3 \mathrm{H}) ;{ }^{13} \mathrm{C}-\mathrm{NMR}\left(101 \mathrm{MHz}, \mathrm{DMSO}-d_{6}\right) \delta$ 159.4, 157.4, 153.7, 137.3, 129.1, 123.8, 120.3, 118.6, 110.8, 97.0, 60.0, 56.3, 54.9, 52.9, 32.6, 27.6, 24.5, 19.6, 11.7; ESI-MS: $(\mathrm{m} / \mathrm{z}) 358.2[\mathrm{M}+\mathrm{H}]^{+}$, $380.1[\mathrm{M}+\mathrm{Na}]^{+}, 356.2[\mathrm{M}-\mathrm{H}]^{-} ;$HPLC: $\mathrm{t}_{\mathrm{r}}=4.200 \mathrm{~min}(99.3 \%$ purity).

7-Chloro- $N$-(1-isopropylpiperidin-3-yl)- $N$-methyl-9H-pyrimido[4,5-b]indol-4-amine (14f). 14f was prepared from $13 \mathbf{b}(62.0 \mathrm{mg}, 0.20 \mathrm{mmol})$, acetone $(228.1 \mathrm{mg}, 3.93 \mathrm{mmol})$, glacial $\mathrm{AcOH}(23.6 \mathrm{mg}, 0.39$ $\mathrm{mmol})$ and $\mathrm{Na}(\mathrm{OAc})_{3} \mathrm{BH}(83.2 \mathrm{mg}, 0.39 \mathrm{mmol})$ in dry $\mathrm{DCM}(10 \mathrm{~mL})$ according to general procedure $\mathrm{E}$ in a reaction time of $5 \mathrm{~h}$. A second portion of acetone $(228.1 \mathrm{mg}, 3.93 \mathrm{mmol})$ was added after $3 \mathrm{~h}$. Purification by flash column chromatography $\left(\mathrm{SiO}_{2}, \mathrm{DCM} 2 \mathrm{~N} \mathrm{NH}_{3}\right.$ in $\mathrm{MeOH}$ 95:5 to 92.5:7.5) gave 30 $\mathrm{mg}$ of a beige solid $\left(43 \%\right.$ yield); ${ }^{1} \mathrm{H}-\mathrm{NMR}\left(400 \mathrm{MHz}, \mathrm{DMSO}-d_{6}\right) \delta 12.20(\mathrm{~s}, 1 \mathrm{H}), 8.39(\mathrm{~s}, 1 \mathrm{H}), 7.79(\mathrm{~d}, J$ $=8.7 \mathrm{~Hz}, 1 \mathrm{H}), 7.47(\mathrm{~d}, J=2.0 \mathrm{~Hz}, 1 \mathrm{H}), 7.24(\mathrm{dd}, J=8.6,2.0 \mathrm{~Hz}, 1 \mathrm{H}), 4.46-4.35(\mathrm{~m}, 1 \mathrm{H}), 3.16(\mathrm{~s}, 3 \mathrm{H})$, 2.96-2.86 (m, 1H), 2.79-2.66 (m, 2H), 2.48-2.41 (m, 1H), 2.16-2.03 (m, 1H), 1.86-1.67 (m, 3H), 1.55-1.41 $(\mathrm{m}, 1 \mathrm{H}), 1.05-0.92(\mathrm{~m}, 6 \mathrm{H}) ;{ }^{13} \mathrm{C}-\mathrm{NMR}\left(50 \mathrm{MHz}, \mathrm{DMSO}-d_{6}\right) \delta 159.4,157.4,153.8,137.3,129.1,123.9,120.3$, 118.6, 110.8, 97.0, 55.5, 54.0, 51.3, 48.1, 32.7, 28.0, 24.8, 18.1, 17.7; ESI-MS: $(\mathrm{m} / \mathrm{z}) 357.8[\mathrm{M}+\mathrm{H}]^{+}, 355.8[\mathrm{M}$ - H] ; HPLC: $\mathrm{t}_{\mathrm{r}}=4.291 \mathrm{~min}(99.0 \%$ purity).

7-Chloro- $N$-(1-cyclopentylpiperidin-3-yl)- $N$-methyl-9H-pyrimido[4,5-b]indol-4-amine (14g). $\mathbf{1 4 g}$ was prepared from $13 \mathbf{b}(60.0 \mathrm{mg}, 0.19 \mathrm{mmol})$, cyclopentanone $(63.9 \mathrm{mg}, 0.76 \mathrm{mmol})$, glacial $\mathrm{AcOH}(22.8$ $\mathrm{mg}, 0.38 \mathrm{mmol})$ and $\mathrm{Na}(\mathrm{OAc})_{3} \mathrm{BH}(80.5 \mathrm{mg}, 0.38 \mathrm{mmol})$ in dry DCM $(10 \mathrm{~mL})$ according to general procedure $\mathrm{E}$ in a reaction time of $3 \mathrm{~h}$. Purification by flash column chromatography $\left(\mathrm{SiO}_{2}, \mathrm{DCM}: 2 \mathrm{~N}\right.$ $\mathrm{NH}_{3} \mathrm{MeOH}$ gradient elution from $96: 4$ to $\left.93: 7\right)$ gave $54 \mathrm{mg}$ of a white solid (74\% yield); ${ }^{1} \mathrm{H}-\mathrm{NMR}$ (400 
MHz, DMSO- $\left.d_{6}\right) \delta 12.21(\mathrm{~s}, 1 \mathrm{H}), 8.38(\mathrm{~s}, 1 \mathrm{H}), 7.79(\mathrm{~d}, J=8.7 \mathrm{~Hz}, 1 \mathrm{H}), 7.47(\mathrm{~d}, J=1.9 \mathrm{~Hz}, 1 \mathrm{H}), 7.24(\mathrm{dd}, J$ $=8.6,2.0 \mathrm{~Hz}, 1 \mathrm{H}), 4.47-4.35(\mathrm{~m}, 1 \mathrm{H}), 3.14(\mathrm{~s}, 3 \mathrm{H}), 3.09-3.01(\mathrm{~m}, 1 \mathrm{H}), 2.94-2.84(\mathrm{~m}, 1 \mathrm{H}), 2.58-2.52(\mathrm{~m}, 1 \mathrm{H}$, overlap with DMSO- $\left.d_{5}\right), 2.30-2.17(\mathrm{~m}, 1 \mathrm{H}), 1.93-1.67(\mathrm{~m}, 6 \mathrm{H}), 1.64-1.39(\mathrm{~m}, 5 \mathrm{H}), 1.38-1.25(\mathrm{~m}, 2 \mathrm{H})$; ${ }^{13}$ C-NMR (101 MHz, DMSO- $\left.d_{6}\right) \delta 159.4,157.4,153.7,137.3,129.1,123.8,120.2,118.6,110.8,96.9,66.7$, 55.0, 54.8, 51.5, 32.6, 29.8, 29.6, 27.6, 24.5, 23.6; ESI-MS: $(\mathrm{m} / \mathrm{z}) 383.8[\mathrm{M}+\mathrm{H}]^{+}, 381.8[\mathrm{M}-\mathrm{H}]^{-}$; HPLC: $\mathrm{t}_{\mathrm{r}}=$ $4.839 \mathrm{~min}(100.0 \%$ purity).

7-Chloro- $N$-(1-(furan-2-ylmethyl)piperidin-3-yl)- $N$-methyl-9H-pyrimido[4,5-b]indol-4-amine (14h). 14h was prepared from $\mathbf{1 3 b}(80.0 \mathrm{mg}, 0.25 \mathrm{mmol})$, furan-2-carbaldehyde ( $30.4 \mathrm{mg}, 0.32 \mathrm{mmol})$, glacial $\mathrm{AcOH}(30.4 \mathrm{mg}, 0.51 \mathrm{mmol})$ and $\mathrm{Na}(\mathrm{OAc})_{3} \mathrm{BH}(80.5 \mathrm{mg}, 0.38 \mathrm{mmol})$ in dry $\mathrm{DCM}(10 \mathrm{~mL})$ according to general procedure $\mathrm{E}$ in a reaction time of $6.5 \mathrm{~h}$. Purification by flash column chromatography $\left(\mathrm{SiO}_{2}\right.$, 1.DCM:MeOH gradient elution from 96:4 to 92.5:7.5, 2.DCM:MeOH gradient elution from 96:4 to 92:8) gave $55 \mathrm{mg}$ of an off-white solid (55\% yield); ${ }^{1} \mathrm{H}-\mathrm{NMR}\left(300 \mathrm{MHz}, \mathrm{CDCl}_{3}\right) \delta 11.76(\mathrm{br} \mathrm{s}, 1 \mathrm{H}), 8.54(\mathrm{~s}, 1 \mathrm{H})$, $7.63(\mathrm{~d}, J=8.6 \mathrm{~Hz}, 1 \mathrm{H}), 7.49-7.37(\mathrm{~m}, 2 \mathrm{H}), 7.21(\mathrm{dd}, J=8.6,1.8 \mathrm{~Hz}, 1 \mathrm{H}), 6.39-6.31(\mathrm{~m}, 1 \mathrm{H}), 6.30-6.22(\mathrm{~m}$, $1 \mathrm{H}), 4.69-4.50(\mathrm{~m}, 1 \mathrm{H}), 3.71(\mathrm{~d}, J=14.2 \mathrm{~Hz}, 1 \mathrm{H}), 3.64(\mathrm{~d}, J=14.2 \mathrm{~Hz}, 1 \mathrm{H}), 3.28-3.14(\mathrm{~m}, 4 \mathrm{H}), 3.03-2.92$ (m, 1H), 2.50-2.37 (m, 1H), 2.14-2.02 (m, 1H), 2.00-1.90 (m, 1H), 1.88-1.71 (m, 3H) ${ }^{13} \mathrm{C}-\mathrm{NMR}(50 \mathrm{MHz}$, $\left.\mathrm{CDCl}_{3}\right) \delta 160.3,157.6,153.1,151.4,142.5,137.3,130.8,123.7,121.3,119.0,111.4,110.4,109.4,98.7,56.1$, 55.7, 54.9, 53.2, 33.2, 28.0, 24.7.; ESI-MS: $(m / z) 396.1[\mathrm{M}+\mathrm{H}]^{+}, 418.1[\mathrm{M}+\mathrm{Na}]^{+}, 393.9[\mathrm{M}-\mathrm{H}]^{-} ;$HPLC: $\mathrm{t}_{\mathrm{r}}=4.781 \mathrm{~min}(99.7 \%$ purity).

7-Chloro- $N$-methyl-N-(1-(pyridin-4-ylmethyl)piperidin-3-yl)-9H-pyrimido[4,5-b]indol-4-amine (14i). $\mathbf{1 4} \mathbf{i}$ was prepared from $\mathbf{1 3 \mathbf { b }}(75.0 \mathrm{mg}, 0.24 \mathrm{mmol})$, pyridin-4-carbaldehyde $(38.2 \mathrm{mg}, 0.36 \mathrm{mmol})$, glacial $\mathrm{AcOH}(28.5 \mathrm{mg}, 0.48 \mathrm{mmol})$ and $\mathrm{Na}(\mathrm{OAc})_{3} \mathrm{BH}(100.7 \mathrm{mg}, 0.48 \mathrm{mmol})$ in dry $\mathrm{DCM}(10 \mathrm{~mL})$ according to general procedure $\mathrm{E}$ in a reaction time of $2.5 \mathrm{~h}$. Purification by flash column chromatography $\left(\mathrm{SiO}_{2}\right.$, DCM:MeOH gradient elution from 95:5 to $90.5: 9.5)$ gave $71 \mathrm{mg}$ of a white solid (73\% yield); ${ }^{1} \mathrm{H}-\mathrm{NMR}$ $\left(400 \mathrm{MHz}\right.$, DMSO- $\left.d_{6}\right) \delta 12.22(\mathrm{~s}, 1 \mathrm{H}), 8.49(\mathrm{~d}, J=5.7 \mathrm{~Hz}, 2 \mathrm{H}), 8.37(\mathrm{~s}, 1 \mathrm{H}), 7.69(\mathrm{~d}, J=8.6 \mathrm{~Hz}, 1 \mathrm{H}), 7.48$ $(\mathrm{d}, J=1.8 \mathrm{~Hz}, 1 \mathrm{H}), 7.32(\mathrm{~d}, J=5.6 \mathrm{~Hz}, 2 \mathrm{H}), 7.22(\mathrm{dd}, J=8.6,1.8 \mathrm{~Hz}, 1 \mathrm{H}), 4.54-4.41(\mathrm{~m}, 1 \mathrm{H}), 3.59-3.48(\mathrm{~m}$, $2 \mathrm{H}), 3.13(\mathrm{~s}, 3 \mathrm{H}), 2.98-2.88(\mathrm{~m}, 1 \mathrm{H}), 2.80-2.70(\mathrm{~m}, 1 \mathrm{H}), 2.37-2.27(\mathrm{~m}, 1 \mathrm{H}), 2.00-1.89(\mathrm{~m}, 1 \mathrm{H}), 1.86-1.65$ $(\mathrm{m}, 3 \mathrm{H}), 1.62-1.48(\mathrm{~m}, 1 \mathrm{H}){ }^{13} \mathrm{C}-\mathrm{NMR}\left(50 \mathrm{MHz}, \mathrm{DMSO}-d_{6}\right) \delta$ 159.4, 157.5, 153.7, 149.5, 147.5, 137.4, 129.2, 123.8, 123.7, 120.3, 118.5, 110.9, 97.0, 60.8, 55.9, 54.8, 52.8, 32.8, 27.2, 24.4; ESI-MS: $(m / z) 407.4[\mathrm{M}+\mathrm{H}]^{+}$, $405.2[\mathrm{M}-\mathrm{H}]^{-}$; HPLC: $\mathrm{t}_{\mathrm{r}}=6.121 \mathrm{~min}(99.5 \%$ purity).

3-((3-((7-Chloro-9H-pyrimido[4,5-b]indol-4-yl)(methyl)amino)piperidin-1-yl)methyl)benzonitrile (14j). $\mathbf{1 4} \mathbf{j}$ was prepared from $\mathbf{1 3 \mathbf { b }}(25.0 \mathrm{mg}, 0.08 \mathrm{mmol}), 3$-formylbenzonitrile $(31.1 \mathrm{mg}, 0.24 \mathrm{mmol})$, glacial $\mathrm{AcOH}(9.5 \mathrm{mg}, 0.16 \mathrm{mmol})$ and $\mathrm{Na}(\mathrm{OAc})_{3} \mathrm{BH}(33.6 \mathrm{mg}, 0.16 \mathrm{mmol})$ in dry $\mathrm{DCM}(4 \mathrm{~mL})$ according to general procedure $\mathrm{E}$ in a reaction time of $4 \mathrm{~h}$. Purification by flash column chromatography $\left(\mathrm{SiO}_{2}\right.$, DCM:MeOH gradient elution from $96: 4$ to $93: 7)$ gave $20 \mathrm{mg}$ of a white solid (59\% yield); ${ }^{1} \mathrm{H}-\mathrm{NMR}$ (400 $\left.\mathrm{MHz}, \mathrm{DMSO}-d_{6}\right) \delta 12.20(\mathrm{~s}, 1 \mathrm{H}), 8.37(\mathrm{~s}, 1 \mathrm{H}), 7.77(\mathrm{br} \mathrm{s}, 1 \mathrm{H}), 7.75-7.64(\mathrm{~m}, 3 \mathrm{H}), 7.54(\mathrm{t}, J=7.7 \mathrm{~Hz}, 1 \mathrm{H})$, $7.47(\mathrm{~d}, J=2.0 \mathrm{~Hz}, 1 \mathrm{H}), 7.21(\mathrm{dd}, J=8.6,2.0 \mathrm{~Hz}, 1 \mathrm{H}), 4.54-4.41(\mathrm{~m}, 1 \mathrm{H}), 3.61(\mathrm{~d}, J=13.7 \mathrm{~Hz}, 1 \mathrm{H}), 3.54$ $(\mathrm{d}, J=13.7 \mathrm{~Hz}, 1 \mathrm{H}), 3.14(\mathrm{~s}, 3 \mathrm{H}), 3.01-2.91(\mathrm{~m}, 1 \mathrm{H}), 2.82-2.72(\mathrm{~m}, 1 \mathrm{H}), 2.37-2.26(\mathrm{~m}, 1 \mathrm{H}), 2.02-1.90(\mathrm{~m}$, 1H), 1.84-1.67 (m, 3H), 1.61-1.48 (m, 1H); ${ }^{13} \mathrm{C}-\mathrm{NMR}$ (50 MHz, DMSO-d $\left.d_{6}\right) \delta 159.4,157.4,153.7,140.2$, 137.4, 133.7, 132.1, 130.9, 129.4, 129.2, 123.8, 120.3, 118.9, 118.5, 111.2, 110.9, 97.0, 61.0, 55.6, 54.8, 52.8, 32.8, 27.2, 24.4; ESI-MS: $(\mathrm{m} / \mathrm{z}) 431.2\left[\mathrm{M}+\mathrm{H}^{+}, 453.2[\mathrm{M}+\mathrm{Na}]^{+}, 429.2[\mathrm{M}-\mathrm{H}]^{-} ;\right.$HPLC: $\mathrm{t}_{\mathrm{r}}=4.879 \mathrm{~min}$ (100.0\% purity).

7-Chloro- $N$-methyl- $N$-(1-(3,3,3-trifluoropropyl)piperidin-3-yl)-9H-pyrimido[4,5-b]indol-4-amine (14k). $\mathbf{1 4 k}$ was prepared from $\mathbf{1 3 b}(55.0 \mathrm{mg}, 0.17 \mathrm{mmol})$, trifluoropropanal $(97.6 \mathrm{mg}, 0.87 \mathrm{mmol})$, glacial AcOH $(20.9 \mathrm{mg}, 0.35 \mathrm{mmol})$ and $\mathrm{Na}(\mathrm{OAc})_{3} \mathrm{BH}(73.8 \mathrm{mg}, 0.35 \mathrm{mmol})$ in dry $\mathrm{DCM}(10 \mathrm{~mL})$ according to general procedure $\mathrm{E}$ in a reaction time of $3 \mathrm{~h}$. Purification by flash column chromatography $\left(\mathrm{SiO}_{2}, \mathrm{DCM}: \mathrm{MeOH}\right.$ gradient elution from 97.5:2.5 to 92.5:7.5) gave $38 \mathrm{mg}$ of a white solid (53\% yield); ${ }^{1} \mathrm{H}-\mathrm{NMR}(400 \mathrm{MHz}$, DMSO- $\left.d_{6}\right) \delta 12.20(\mathrm{~s}, 1 \mathrm{H}), 8.39(\mathrm{~s}, 1 \mathrm{H}), 7.76(\mathrm{~d}, J=8.7 \mathrm{~Hz}, 1 \mathrm{H}), 7.48(\mathrm{~d}, J=2.0 \mathrm{~Hz}, 1 \mathrm{H}), 7.26(\mathrm{dd}, J=8.6$, $2.0 \mathrm{~Hz}, 1 \mathrm{H}), 4.49-4.37(\mathrm{~m}, 1 \mathrm{H}), 3.15(\mathrm{~s}, 3 \mathrm{H}), 3.03-2.96(\mathrm{~m}, 1 \mathrm{H}), 2.88-2.79(\mathrm{~m}, 1 \mathrm{H}), 2.61-2.53(\mathrm{~m}, 2 \mathrm{H})$, 
2.51-2.41 (m, 2H, overlapping with DMSO- $\left.d_{5}\right), 2.37-2.26(\mathrm{~m}, 1 \mathrm{H}), 1.96-1.87(\mathrm{~m}, 1 \mathrm{H}), 1.86-1.67(\mathrm{~m}, 3 \mathrm{H})$, 1.59-1.45 (m, 1H); ${ }^{13} \mathrm{C}-\mathrm{NMR}\left(101 \mathrm{MHz}\right.$, DMSO- $\left.d_{6}\right) \delta 159.4,157.4,153.7,137.3,129.1,127.2(\mathrm{q}, J=276.9$ $\mathrm{Hz}), 123.7,120.3,118.5,110.8,97.0,55.8,54.7,52.4,50.4$ (q), 32.6, 30.4 (q, $J=26.3 \mathrm{~Hz}), 27.2,24.3$; ESI-MS: $(\mathrm{m} / \mathrm{z}) 412.3[\mathrm{M}+\mathrm{H}]^{+}, 434.4[\mathrm{M}+\mathrm{Na}]^{+}, 410.3[\mathrm{M}-\mathrm{H}]^{-} ;$HPLC: $\mathrm{t}_{\mathrm{r}}=7.463 \mathrm{~min}$ (97.2\% purity).

2-(3-((7-Chloro-9H-pyrimido[4,5-b]indol-4-yl)(methyl)amino)piperidin-1-yl)acetonitrile (141). 13b (40.0 $\mathrm{mg}, 0.13 \mathrm{mmol})$ was dissolved in dry DMF $(2 \mathrm{~mL})$. 2-Bromoacetonitrile $(16.7 \mathrm{mg}, 0.14 \mathrm{mmol})$ and $\mathrm{Et}_{3} \mathrm{~N}(38.5 \mathrm{mg}, 0.38 \mathrm{mmol})$ were added and the mixture stirred at $\mathrm{rt}$ for $1.5 \mathrm{~h}$. Saturated $\mathrm{NaHCO}_{3}$ solution $(5 \mathrm{~mL})$ was added and the mixture extracted with EtOAc $(6 \times 2 \mathrm{~mL})$. Combined organic layers were diluted with additional EtOAc, washed with saturated $\mathrm{NaHCO}_{3}$ solution $(3 \times 20 \mathrm{~mL})$, dried over $\mathrm{Na}_{2} \mathrm{SO}_{4}$ and concentrated under reduced pressure. Purification of the residue by flash column chromatography $\left(\mathrm{SiO}_{2}, \mathrm{DCM}: \mathrm{MeOH} 96: 4\right)$ gave $41 \mathrm{mg}$ of a beige solid $\left(91 \%\right.$ yield); ${ }^{1} \mathrm{H}-\mathrm{NMR}(400 \mathrm{MHz}$, DMSO- $\left._{6}\right) \delta 12.22(\mathrm{~s}, 1 \mathrm{H}), 8.41(\mathrm{~s}, 1 \mathrm{H}), 7.76(\mathrm{~d}, J=8.6 \mathrm{~Hz}, 1 \mathrm{H}), 7.48(\mathrm{~d}, J=1.9 \mathrm{~Hz}, 1 \mathrm{H}), 7.27(\mathrm{dd}, J=8.6$, $2.0 \mathrm{~Hz}, 1 \mathrm{H}), 4.52-4.41(\mathrm{~m}, 1 \mathrm{H}), 3.75(\mathrm{~s}, 2 \mathrm{H}), 3.18(\mathrm{~s}, 3 \mathrm{H}), 2.95-2.87(\mathrm{~m}, 1 \mathrm{H}), 2.81-2.72(\mathrm{~m}, 1 \mathrm{H}), 2.48-2.42$ $(\mathrm{m}, 1 \mathrm{H}), 2.20-2.09(\mathrm{~m}, 1 \mathrm{H}), 1.95-1.72(\mathrm{~m}, 3 \mathrm{H}), 1.66-1.53(\mathrm{~m}, 1 \mathrm{H}) ;{ }^{13} \mathrm{C}-\mathrm{NMR}\left(101 \mathrm{MHz}\right.$, DMSO- $\left.d_{6}\right) \delta$ 159.5, 157.4, 153.7, 137.4, 129.2, 123.8, 120.4, 118.4, 115.8, 110.8, 97.2, 54.4, 54.1, 51.3, 45.3, 32.8, 26.6, 24.1; ESI-MS: $(\mathrm{m} / \mathrm{z}) 355.0[\mathrm{M}+\mathrm{H}]^{+}, 376.9[\mathrm{M}+\mathrm{Na}]^{+}, 352.9[\mathrm{M}-\mathrm{H}]^{-} ; \mathrm{HPLC}: \mathrm{t}_{\mathrm{r}}=8.358 \mathrm{~min}(99.4 \%$ purity).

7-Chloro- $N$-(1-(cyclopropylmethyl)piperidin-3-yl)- $N$-methyl-9H-pyrimido[4,5-b]indol-4-amine (14m). (Bromomethyl)cyclopropane ( $34.4 \mathrm{mg}, 0.25 \mathrm{mmol}$ ) and $\mathrm{Et}_{3} \mathrm{~N}(33.6 \mathrm{mg}, 0.33 \mathrm{mmol}$ ) were added to a suspension of $\mathbf{1 3 b}(70.0 \mathrm{mg}, 0.22 \mathrm{mmol})$ in HPLC grade acetonitrile $(10 \mathrm{~mL})$. The mixture was stirred at $60{ }^{\circ} \mathrm{C}$ for 2 days and then concentrated under reduced pressure. Purification of the residue by flash column chromatography $\left(\mathrm{SiO}_{2}, \mathrm{DCM}: 2 \mathrm{~N} \mathrm{NH}_{3}\right.$ in $\mathrm{MeOH}$ gradient elution from 98:2 to 91.5:8.5) gave 64 $\mathrm{mg}$ of a white solid $\left(78 \%\right.$ yield); ${ }^{1} \mathrm{H}-\mathrm{NMR}\left(400 \mathrm{MHz}, \mathrm{DMSO}-d_{6}\right) \delta 12.22(\mathrm{~s}, 1 \mathrm{H}), 8.39(\mathrm{~s}, 1 \mathrm{H}), 7.80(\mathrm{~d}, J$ $=8.7 \mathrm{~Hz}, 1 \mathrm{H}), 7.47(\mathrm{~d}, J=2.0 \mathrm{~Hz}, 1 \mathrm{H}), 7.25(\mathrm{dd}, J=8.6,2.0 \mathrm{~Hz}, 1 \mathrm{H}), 4.49-4.38(\mathrm{~m}, 1 \mathrm{H}), 3.14(\mathrm{~s}, 3 \mathrm{H})$, 3.12-3.06 (m, 1H), 2.94-2.87 (m, 1H), 2.30-2.12 (m, 3H), 1.92-1.65 (m, 4H), 1.60-1.45 (m, 1H), 0.91-0.78 (m, 1H), 0.51-0.36 (m, 2H), 0.13-0.00 (m, 2H); ${ }^{13} \mathrm{C}-\mathrm{NMR}\left(101 \mathrm{MHz}, \mathrm{DMSO}-d_{6}\right) \delta 159.4,157.4,153.7$, 137.3, 129.1, 123.8, 120.3, 118.6, 110.8, 97.0, 62.9, 56.1, 54.9, 52.8, 32.5, 27.6, 24.4, 8.3, 3.8, 3.6; ESI-MS: $(\mathrm{m} / \mathrm{z})$ $370.1[\mathrm{M}+\mathrm{H}]^{+}, 392.1[\mathrm{M}+\mathrm{Na}]^{+}, 368.2[\mathrm{M}-\mathrm{H}]^{-} ;$HPLC: $\mathrm{t}_{\mathrm{r}}=4.318 \min (100.0 \%$ purity).

7-Chloro- $N$-(1-(3-(dimethylamino)propyl)piperidin-3-yl)- $N$-methyl-9H-pyrimido[4,5-b] indol-4-amine (14n). $\mathbf{1 3 b}$ (100.0 mg, $0.32 \mathrm{mmol}$ ) and 3-chloro- $\mathrm{N}, \mathrm{N}$-dimethylpropan-1-amine hydrochloride $(65.1 \mathrm{mg}$, $0.41 \mathrm{mmol}$ ) were suspended in HPLC grade acetonitrile $(15 \mathrm{~mL}) . \mathrm{Et}_{3} \mathrm{~N}(96.1 \mathrm{mg}, 0.95 \mathrm{mmol})$ was added. The mixture was stirred at $90{ }^{\circ} \mathrm{C}$ for 2-3 days and then concentrated under reduced pressure. Purification of the residue by flash column chromatography $\left(\mathrm{SiO}_{2}, \mathrm{DCM}: 2 \mathrm{~N} \mathrm{NH}_{3}\right.$ in $\mathrm{MeOH}$ 9:1) gave $50 \mathrm{mg}$ of an off-white solid (39\% yield); ${ }^{1} \mathrm{H}-\mathrm{NMR}\left(300 \mathrm{MHz}, \mathrm{CDCl}_{3}\right) \delta 12.07$ (br s, $\left.1 \mathrm{H}\right), 8.54(\mathrm{~s}, 1 \mathrm{H}), 7.69$ $(\mathrm{d}, J=8.6 \mathrm{~Hz}, 1 \mathrm{H}), 7.44(\mathrm{~d}, J=1.0 \mathrm{~Hz}, 1 \mathrm{H}), 7.21(\mathrm{dd}, J=8.6,1.2 \mathrm{~Hz}, 1 \mathrm{H}), 4.66-4.51(\mathrm{~m}, 1 \mathrm{H}), 3.23(\mathrm{~s}$, $3 \mathrm{H}), 3.18-3.10(\mathrm{~m}, 1 \mathrm{H}), 2.99-2.90(\mathrm{~m}, 1 \mathrm{H}), 2.53-2.20(\mathrm{~m}, 11 \mathrm{H}), 2.02-1.66(\mathrm{~m}, 7 \mathrm{H}) ;{ }^{13} \mathrm{C}-\mathrm{NMR}(101 \mathrm{MHz}$, $\left.\mathrm{CDCl}_{3}\right) \delta 160.3,157.8,153.2,137.5,130.8,123.7,121.2,119.2,111.4,98.6,58.0,57.0,56.8,55.6,53.8,45.3$, 33.1, 28.5, 25.0, 24.9; ESI-MS: $(\mathrm{m} / \mathrm{z}) 401.4[\mathrm{M}+\mathrm{H}]^{+}, 399.4[\mathrm{M}-\mathrm{H}]^{-}$; HPLC: $\mathrm{t}_{\mathrm{r}}=4.318 \mathrm{~min}$.

3-(3-((7-Chloro-9-methyl-9H-pyrimido[4,5-b]indol-4-yl)(methyl)amino)piperidin-1-yl)propanenitrile (14o). $\mathrm{NaH}(8.1 \mathrm{mg}$ of a $60 \%$ dispersion in mineral oil, $0.20 \mathrm{mmol})$ was added to a stirring suspension of $14 \mathbf{b}(50.0 \mathrm{mg}, 0.14 \mathrm{mmol})$ in dry THF $(10 \mathrm{~mL})$. The mixture was stirred at $\mathrm{rt}$ and under $\mathrm{N}_{2}$ atmosphere for $0.5 \mathrm{~h}$. Methyl iodide $(0.5 \mathrm{~mL}$ of a freshly prepared $0.4 \mathrm{M}$ solution in THF, $0.20 \mathrm{mmol})$ was drop-added and the mixture stirred for $20 \mathrm{~h}$ at $\mathrm{rt}$ and under $\mathrm{N}_{2}$ atmosphere. Dimethylamine ( $0.075 \mathrm{~mL}$ of a $2 \mathrm{M}$ solution in THF, $0.15 \mathrm{mmol}$ ) was added to quench excessive methyl iodide and stirring continued for $1 \mathrm{~h}$. Saturated $\mathrm{NH}_{4} \mathrm{Cl}$ solution $(15 \mathrm{~mL})$ was added to stop the reaction and the mixture then basified with saturated $\mathrm{NaHCO}_{3}$ solution. EtOAc was added and phases were separated. The organic layer was washed with saturated $\mathrm{NaHCO}_{3}$ solution $(2 \times 20 \mathrm{~mL})$, dried over $\mathrm{Na}_{2} \mathrm{SO}_{4}$ and concentrated under reduced pressure. Purification of the residue by flash column chromatography $\left(\mathrm{SiO}_{2}\right.$, DCM:MeOH 96.7:3.3 to 93.5:6.5) gave $31 \mathrm{mg}$ of a light beige solid (60\% yield); ${ }^{1} \mathrm{H}-\mathrm{NMR}(400$ 
MHz, DMSO- $\left.d_{6}\right) \delta 8.46(\mathrm{~s}, 1 \mathrm{H}), 7.83-7.74(\mathrm{~m}, 2 \mathrm{H}), 7.38(\mathrm{dd}, J=8.6,1.3 \mathrm{~Hz}, 1 \mathrm{H}), 4.49-4.39(\mathrm{~m}, 1 \mathrm{H}), 3.83$ $(\mathrm{s}, 3 \mathrm{H}), 3.14(\mathrm{~s}, 3 \mathrm{H}), 3.11-3.03(\mathrm{~m}, 1 \mathrm{H}), 2.90-2.82(\mathrm{~m}, 1 \mathrm{H}), 2.76-2.59(\mathrm{~m}, 4 \mathrm{H}), 2.43-2.34(\mathrm{~m}, 1 \mathrm{H}), 2.00-1.89$ $(\mathrm{m}, 1 \mathrm{H}), 1.81-1.66(\mathrm{~m}, 3 \mathrm{H}), 1.55-1.42(\mathrm{~m}, 1 \mathrm{H}) ;{ }^{13} \mathrm{C}-\mathrm{NMR}\left(101 \mathrm{MHz}, \mathrm{DMSO}-d_{6}\right) \delta 159.3,156.8,153.5$, 138.5, 129.5, 123.7, 120.8, 120.0, 118.0, 109.7, 96.7, 55.6, 54.9, 53.0, 52.2, 32.6, 27.9, 27.2, 24.3, 15.0; ESI-MS: $(\mathrm{m} / \mathrm{z}) 383.0[\mathrm{M}+\mathrm{H}]^{+}, 405.0[\mathrm{M}+\mathrm{Na}]^{+} ;$HPLC: $\mathrm{t}_{\mathrm{r}}=4.740 \min (100.0 \%$ purity).

Detailed Procedures for the Preparation of Compounds 15-17

3-(3-((7-Chloro-9H-pyrimido[4,5-b]indol-4-yl)(methyl)amino)pyrrolidin-1-yl)propanenitrile (15). 13a $(60.0 \mathrm{mg}, 0.20 \mathrm{mmol})$ and acrylonitrile $(23.2 \mathrm{mg}, 0.44 \mathrm{mmol})$ were stirred in dry $\mathrm{MeOH}(17 \mathrm{~mL})$ at rt overnight. Volatiles were removed under reduced pressure. Purification of the residue by flash column chromatography $\left(\mathrm{SiO}_{2}, \mathrm{DCM}: \mathrm{MeOH} 96: 4\right.$ to $\left.93: 7\right)$ gave $51 \mathrm{mg}$ of an off-white solid (72\% yield); ${ }^{1} \mathrm{H}-\mathrm{NMR}\left(400 \mathrm{MHz}\right.$, DMSO- $\left.d_{6}\right) \delta 12.22(\mathrm{~s}, 1 \mathrm{H}), 8.41(\mathrm{~s}, 1 \mathrm{H}), 7.84(\mathrm{~d}, J=8.6 \mathrm{~Hz}, 1 \mathrm{H}), 7.48(\mathrm{~d}, J=1.9 \mathrm{~Hz}$, $1 \mathrm{H}), 7.29(\mathrm{dd}, J=8.6,1.9 \mathrm{~Hz}, 1 \mathrm{H}), 5.11-5.01(\mathrm{~m}, 1 \mathrm{H}), 3.24(\mathrm{~s}, 3 \mathrm{H}), 2.98-2.86(\mathrm{~m}, 2 \mathrm{H}), 2.78-2.57(\mathrm{~m}, 5 \mathrm{H})$, $2.43-2.33(\mathrm{~m}, 1 \mathrm{H}), 2.27-2.16(\mathrm{~m}, 1 \mathrm{H}), 2.05-1.94(\mathrm{~m}, 1 \mathrm{H}) ;{ }^{13} \mathrm{C}-\mathrm{NMR}(101 \mathrm{MHz}$, DMSO-d 6 ) $\delta 160.0,157.3$, 153.7, 137.4, 129.2, 123.8, 120.4, 119.8, 118.5, 110.8, 97.6, 56.8, 56.2, 52.9, 50.3, 33.3, 27.8, 16.5; ESI-MS: $(\mathrm{m} / \mathrm{z}) 355.0[\mathrm{M}+\mathrm{H}]^{+}, 377.0[\mathrm{M}+\mathrm{Na}]^{+}, 353.0[\mathrm{M}-\mathrm{H}]^{-} ;$HPLC: $\mathrm{t}_{\mathrm{r}}=3.414 \mathrm{~min}(100.0 \%$ purity).

3-(4-((7-Chloro-9H-pyrimido[4,5-b]indol-4-yl)(methyl)amino)azepan-1-yl)propanenitrile (16). 13c (65.0 $\mathrm{mg}, 0.20 \mathrm{mmol})$ and acrylonitrile $(23.0 \mathrm{mg}, 0.43 \mathrm{mmol})$ were stirred in HPLC grade $\mathrm{MeOH}(20 \mathrm{~mL})$ at rt and under $\mathrm{N}_{2}$ overnight. Additional acrylonitrile was added repeatedly, but conversion seized at $\sim 80 \%$ as calculated by HPLC. Volatiles were removed under reduced pressure. Purification of the residue by flash column chromatography $\left(\mathrm{SiO}_{2}, \mathrm{DCM}: \mathrm{MeOH} 95: 5\right)$ gave $50 \mathrm{mg}$ of a beige solid $(66 \%$ yield); ${ }^{1} \mathrm{H}-\mathrm{NMR}\left(400 \mathrm{MHz}, \mathrm{CDCl}_{3}\right) \delta 12.59$ (br s, 1H), $8.53(\mathrm{~s}, 1 \mathrm{H}), 7.65(\mathrm{~d}, J=8.5 \mathrm{~Hz}, 1 \mathrm{H}), 7.44(\mathrm{~s}, 1 \mathrm{H})$, $7.21(\mathrm{~d}, J=8.5 \mathrm{~Hz}, 1 \mathrm{H}), 4.74-4.62(\mathrm{~m}, 1 \mathrm{H}), 3.22(\mathrm{~s}, 3 \mathrm{H}), 2.91(\mathrm{t}, J=6.8 \mathrm{~Hz}, 2 \mathrm{H}), 2.87-2.71(\mathrm{~m}, 4 \mathrm{H}), 2.52(\mathrm{t}$, $J=6.6 \mathrm{~Hz}, 2 \mathrm{H}), 2.13-1.87(\mathrm{~m}, 5 \mathrm{H}), 1.80-1.67(\mathrm{~m}, 1 \mathrm{H}) ;{ }^{13} \mathrm{C}-\mathrm{NMR}\left(101 \mathrm{MHz}, \mathrm{CDCl}_{3}\right) \delta 160.0,157.7,153.0$, 137.4, 130.8, 123.5, 121.1, 119.1, 119.0, 111.5, 98.4, 58.4, 54.8, 54.0, 51.7, 32.9, 32.5, 30.9, 25.7, 16.8; ESI-MS: $(\mathrm{m} / \mathrm{z}) 405.1[\mathrm{M}+\mathrm{Na}]^{+}, 381.1[\mathrm{M}-\mathrm{H}]^{-} ;$HPLC: $\mathrm{t}_{\mathrm{r}}=3.102 \mathrm{~min}$ (98.4\% purity).

3-(4-((7-Chloro-9H-pyrimido[4,5-b]indol-4-yl)(methyl)amino)piperidin-1-yl)propanenitrile (17). 13d $(34.0 \mathrm{mg}, 0.11 \mathrm{mmol})$ and acrylonitrile $(8.6 \mathrm{mg}, 0.16 \mathrm{mmol})$ were stirred in dry $\mathrm{MeOH}(10 \mathrm{~mL})$ at $\mathrm{rt}$ and under $\mathrm{N}_{2}$ atmosphere overnight. Volatiles were removed under reduced pressure. Purification of the residue by flash column chromatography $\left(\mathrm{SiO}_{2}, \mathrm{DCM}: \mathrm{MeOH}\right.$ 97:3 to 95:5) gave $31 \mathrm{mg}$ of a pale yellow solid (78\% yield); ${ }^{1} \mathrm{H}-\mathrm{NMR}\left(200 \mathrm{MHz}\right.$, DMSO- $\left.d_{6}\right) \delta 12.19(\mathrm{~s}, 1 \mathrm{H}), 8.39(\mathrm{~s}, 1 \mathrm{H}), 7.74(\mathrm{~d}, J=8.7 \mathrm{~Hz}, 1 \mathrm{H})$, $7.48(\mathrm{~d}, J=1.9 \mathrm{~Hz}, 1 \mathrm{H}), 7.26(\mathrm{dd}, J=8.6,2.0 \mathrm{~Hz}, 1 \mathrm{H}), 4.41-4.19(\mathrm{~m}, 1 \mathrm{H}), 3.14(\mathrm{~s}, 3 \mathrm{H}), 3.07-2.91(\mathrm{~m}, 2 \mathrm{H})$, 2.73-2.53 (m, 4H), 2.19-1.65 (m, 6H); ${ }^{13} \mathrm{C}-\mathrm{NMR}\left(50 \mathrm{MHz}, \mathrm{DMSO}-d_{6}\right) \delta 159.6,157.5,153.8,137.4,129.2$, 123.7, 120.4, 120.1, 118.6, 110.9, 97.2, 55.5, 52.7, 52.2, 32.5, 28.3, 15.2; ESI-MS: $(\mathrm{m} / \mathrm{z}) 369.0$ [M + H] $]^{-} ; 391.0$ $[\mathrm{M}+\mathrm{Na}]^{+}, 367.0[\mathrm{M}-\mathrm{H}]^{-} ;$HPLC: $\mathrm{t}_{\mathrm{r}}=3.474 \min (100.0 \%$ purity).

\section{Detailed Procedures for the Preparation of Intermediates 19-23 and Compound 24}

tert-Butyl-1H-pyrrolo[2,3-c]pyridine-1-carboxylate (19). A solution of $1 H$-pyrrolo[2,3-c]pyridine (18) (500.0 mg, $4.23 \mathrm{mmol}$ ) in dry THF (5 mL) was stirred under $\mathrm{N}_{2}$ atmosphere and with ice-cooling. Boc anhydride (1108.4 mg, $5.08 \mathrm{mmol}$ ) was added dropwise. The mixture was left to warm to rt and stirred overnight under $\mathrm{N}_{2}$ atmosphere. After diluting with EtOAc the mixture was washed with saturated $\mathrm{NaHCO}_{3}$ solution $(2 \times 20 \mathrm{~mL})$ and saturated $\mathrm{NaCl}$ solution $(20 \mathrm{~mL})$, dried over $\mathrm{Na}_{2} \mathrm{SO}_{4}$ and concentrated under reduced pressure. Purification of the residue by flash column chromatography $\left(\mathrm{SiO}_{2}, \mathrm{DCM}: \mathrm{MeOH}\right.$ 97.5:2.5) gave $846 \mathrm{mg}$ of a yellow oil (92\% yield); ${ }^{1} \mathrm{H}-\mathrm{NMR}$ (300 MHz, DMSO- $\left.d_{6}\right) \delta$ $9.25(\mathrm{~s}, 1 \mathrm{H}), 8.34(\mathrm{~d}, J=5.3 \mathrm{~Hz}, 1 \mathrm{H}), 7.86(\mathrm{~d}, J=3.6 \mathrm{~Hz}, 1 \mathrm{H}), 7.63(\mathrm{dd}, J=5.3,1.1 \mathrm{~Hz}, 1 \mathrm{H}), 6.77(\mathrm{dd}, J=$ 3.6, $0.6 \mathrm{~Hz}, 1 \mathrm{H}), 1.64(\mathrm{~s}, 9 \mathrm{H}) ;{ }^{13} \mathrm{C}-\mathrm{NMR}\left(75 \mathrm{MHz}, \mathrm{DMSO}-d_{6}\right) \delta 148.4,141.7,136.5,135.5,131.5,129.5$, 115.7, 106.5, 84.8, 27.6; HPLC: $\mathrm{t}_{\mathrm{r}}=2.259 \mathrm{~min}$.

tert-Butyl-octahydro-1H-pyrrolo[2,3-c]pyridine-1-carboxylate (20). 19 (746.0 mg, $3.42 \mathrm{mmol})$ was dissolved in glacial $\mathrm{AcOH}(50 \mathrm{~mL})$ and $\mathrm{PtO}_{2}(150.0 \mathrm{mg}, 20 \%(\mathrm{~m} / \mathrm{m}))$ was added. The mixture was stirred 
in a reactor charged with 5 bar of $\mathrm{H}_{2}$ pressure at $\mathrm{rt}$ for $35 \mathrm{~h}$, then diluted with EtOAc and filtered over a pad of celite rinsing with EtOAc. The filtrate was concentrated under reduced pressure, redissolved in DCM and washed with saturated $\mathrm{NaHCO}_{3}$ solution $(2 \times 20 \mathrm{~mL})$ adding saturated $\mathrm{NaCl}$ solution to improve phase separation. Combined aqueous layers were re-extracted with DCM (25 mL). Combined organic layers were dried over $\mathrm{Na}_{2} \mathrm{SO}_{4}$ and concentrated under reduced pressure to give $680 \mathrm{mg}$ of a yellow oil ( $88 \%$ crude yield), which was used in the next step without further purification; GC-MS $\operatorname{method} A: \mathrm{t}_{\mathrm{r}}=4.974 \mathrm{~min},(\mathrm{~m} / \mathrm{z}) 226[\mathrm{M}]$.

tert-Butyl-6-(2-cyanoethyl)octahydro-1H-pyrrolo[2,3-c]pyridine-1-carboxylate (21). 20 (340.0 mg, 1.50 mmol) was dissolved in HPLC grade $\mathrm{MeOH}(50 \mathrm{~mL})$ and acrylonitrile $(175.4 \mathrm{mg}, 3.31 \mathrm{mmol})$ was added. The mixture was stirred at $\mathrm{rt}$ and under $\mathrm{N}_{2}$ atmosphere overnight. Volatiles were removed under reduced pressure. Purification of the residue by flash column chromatography $\left(\mathrm{SiO}_{2}\right.$, petroleum ether:EtOAc 35:65) gave $350 \mathrm{mg}$ of a yellow oil (83\% yield); ${ }^{1} \mathrm{H}-\mathrm{NMR}\left(300 \mathrm{MHz}, \mathrm{CDCl}_{3}\right) \delta 3.91-3.73(\mathrm{~m}$, $1 \mathrm{H}), 3.43-3.18(\mathrm{~m}, 2 \mathrm{H}), 2.99-2.86(\mathrm{~m}, 1 \mathrm{H}), 2.65(\mathrm{t}, J=7.2 \mathrm{~Hz}, 2 \mathrm{H}), 2.60-2.48(\mathrm{~m}, 1 \mathrm{H}), 2.44(\mathrm{t}, J=6.8 \mathrm{~Hz}$, 2H), 2.33-1.54 (m, 7H), 1.40 (s, 9H); ${ }^{13} \mathrm{C}-\mathrm{NMR}\left(75 \mathrm{MHz} \mathrm{CDCl}_{3}\right) \delta 154.5,154.3,118.9,118.8,79.3,79.1$, 55.0, 53.8, 53.4, 53.1, 49.2, 48.6, 45.4, 44.9, 35.1, 34.5, 28.5, 26.7, 25.8, 25.7, 25.5, 15.8; GC-MS method A: $\mathrm{t}_{\mathrm{r}}$ $=8.701 \mathrm{~min},(\mathrm{~m} / \mathrm{z}) 279[\mathrm{M}]$.

3-(Octahydro-6H-pyrrolo[2,3-c]pyridin-6-yl)propanenitrile (22). 21 (300.0 mg, $1.07 \mathrm{mmol}$ ) was dissolved in dry DCM $(6 \mathrm{~mL})$ under Ar atmosphere. $4 \mathrm{~N} \mathrm{HCl}$ in dioxane $(2.7 \mathrm{~mL})$ was added to the stirring solution resulting in a waxy precipitate. The reaction progress was monitored by a ninhydrin stained TLC. After full consumption of 21, demineralized water was added to dissolve the waxy precipitate. The $\mathrm{pH}$ of the aqueous layer was adjusted to 14 with $50 \% \mathrm{NaOH}_{(\mathrm{aq})}$. Phases were separated and the aqueous layer was extracted with DCM $(15 \times 15 \mathrm{~mL})$. Combined organic layers were dried over $\mathrm{Na}_{2} \mathrm{SO}_{4}$ and concentrated under reduced pressure. $160 \mathrm{mg}$ of an orange oil (83\% yield), which was used in the next step without further purification. A partial hydrolysis of the nitrile group to an amide group was observed in the NMR spectra of the crude product. A small batch was purified by flash column chromatography for analytical purposes $\left(\mathrm{SiO}_{2}, \mathrm{DCM}: 2 \mathrm{~N} \mathrm{NH}_{3}\right.$ in $\left.\mathrm{MeOH} 9: 1\right) ;{ }^{1} \mathrm{H}-\mathrm{NMR}(400$

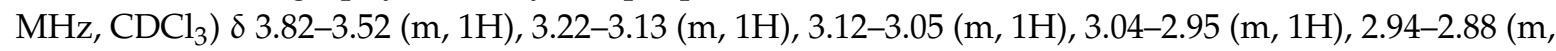
$1 \mathrm{H}), 2.72-2.60(\mathrm{~m}, 3 \mathrm{H}), 2.49(\mathrm{t}, J=6.9 \mathrm{~Hz}, 2 \mathrm{H}), 2.45-2.38(\mathrm{~m}, 1 \mathrm{H}), 2.16-2.07(\mathrm{~m}, 1 \mathrm{H}), 2.01-1.93(\mathrm{~m}, 1 \mathrm{H})$, 1.91-1.82 (m, 1H), 1.64-1.54 (m, 2H), 1.49-1.40 (m, 1H); ${ }^{13} \mathrm{C}-\mathrm{NMR}\left(75 \mathrm{MHz}, \mathrm{CDCl}_{3}\right) \delta 118.9,57.8,53.7$, $53.3,51.9,44.2,35.8,31.2,27.1,16.0 ;$ GC-MS method B: $t_{r}=14.130 \mathrm{~min},(\mathrm{~m} / z) 179[\mathrm{M}]$.

3-(1-(7-Chloro-9-tosyl-9H-pyrimido[4,5-b] indol-4-yl)octahydro-6H-pyrrolo[2,3-c]pyridin-6-yl)propanenitrile (23). 10 (200.0 mg, $0.51 \mathrm{mmol}), 22$ (109.7 mg, $0.61 \mathrm{mmol})$ and DIPEA (210.9 mg, $1.63 \mathrm{mmol})$ were mixed with dry DMF (6 mL). The mixture was stirred at $80{ }^{\circ} \mathrm{C}$ for $1 \mathrm{~h}$ and was then left to cool to rt. Saturated $\mathrm{NaCl}$ solution $(15 \mathrm{~mL})$ was added and the mixture extracted with EtOAc $(3 \times 25 \mathrm{~mL})$. Combined organic layers were washed with saturated $\mathrm{NaCl}$ solution $(3 \times 20 \mathrm{~mL})$, dried over $\mathrm{Na}_{2} \mathrm{SO}_{4}$ and concentrated under reduced pressure. Purification of the residue by flash column chromatography $\left(\mathrm{SiO}_{2}\right.$, petroleum ether:(EtOAc $\left.\left.+\mathrm{MeOH} 95+5\right) 4: 6\right)$ gave $175 \mathrm{mg}$ of a beige solid (64\% yield); ${ }^{1} \mathrm{H}-\mathrm{NMR}$ $\left(300 \mathrm{MHz}, \mathrm{CDCl}_{3}\right) \delta 8.56-8.48(\mathrm{~m}, 2 \mathrm{H}), 8.10(\mathrm{~d}, J=8.4 \mathrm{~Hz}, 2 \mathrm{H}), 7.77(\mathrm{br} \mathrm{s}, 1 \mathrm{H}), 7.36(\mathrm{dd}, J=8.5,1.2 \mathrm{~Hz}$, $1 \mathrm{H}), 7.27\left(\mathrm{~d}, 2 \mathrm{H}\right.$, overlapping with $\mathrm{CHCl}_{3}$ signal), 4.65-4.48 (m, 1H), 4.24-4.06 (m, 1H), 3.53-3.41 (m, 1H), 3.17-3.01 (m, 1H), 2.82-2.52 (m, 4H), 2.49-2.27 (m, 7H), 1.98-1.69 (m, 4H); ${ }^{13} \mathrm{C}-\mathrm{NMR}(75 \mathrm{MHz}$, $\left.\mathrm{CDCl}_{3}\right) \delta 158.0,156.9,154.2,145.7,136.0,135.6,132.2,129.8,128.2,124.2,123.5,120.7,118.8,114.5,100.3$, 57.5, 53.5, 53.4, 50.8, 34.6, 29.8, 26.8, 21.8, 15.8. Signal overlap assumed at 50.8; ESI-MS: $(\mathrm{m} / \mathrm{z}) 534.9$ [M + $\mathrm{H}]^{+}, 556.8[\mathrm{M}+\mathrm{Na}]^{+}, 532.9[\mathrm{M}-\mathrm{H}]^{-} ; \mathrm{HPLC}: \mathrm{t}_{\mathrm{r}}=7.197 \mathrm{~min}$.

3-(3aRS,7aSR)-(1-(7-Chloro-9H-pyrimido[4,5-b]indol-4-yl)octahydro-6H-pyrrolo[2,3-c]pyridin-6-yl)propanenitrile (24). 23 (150.0 mg, $0.28 \mathrm{mmol})$ was dissolved in dry THF (10 mL) and KtBuO (220.2 mg, $1.96 \mathrm{mmol}$ ) was added. The mixture was stirred at $\mathrm{rt}$ and under $\mathrm{N}_{2}$ atmosphere for $75 \mathrm{~min}$. Saturated $\mathrm{NaCl}$ solution $(25 \mathrm{~mL})$ was added and the mixture extracted with EtOAc $(3 \times 25 \mathrm{~mL})$. Combined organic layers were dried over $\mathrm{Na}_{2} \mathrm{SO}_{4}$ and concentrated under reduced pressure. Purification of the 
residue by flash column chromatography $\left(\mathrm{SiO}_{2}, \mathrm{DCM}: \mathrm{MeOH} 95: 5\right)$ gave $59 \mathrm{mg}$ of a light beige solid (55\% yield); ${ }^{1} \mathrm{H}-\mathrm{NMR}\left(300 \mathrm{MHz}\right.$, pyridine- $\left.d_{5}\right) \delta 13.68$ (br s, $\left.1 \mathrm{H}\right), 8.84(\mathrm{~s}, 1 \mathrm{H}), 8.23(\mathrm{~d}, J=8.8 \mathrm{~Hz}, 1 \mathrm{H})$, $7.81(\mathrm{~d}, J=2.0 \mathrm{~Hz}, 1 \mathrm{H}), 7.52(\mathrm{dd}, J=8.7,2.0 \mathrm{~Hz}, 1 \mathrm{H}), 4.95-4.86(\mathrm{~m}, 1 \mathrm{H}), 4.42-4.22(\mathrm{~m}, 1 \mathrm{H}), 4.03-3.86(\mathrm{~m}$, 1H), 3.18-3.02 (m, 1H), 2.74-2.53 (m, 5H), 2.50-2.25 (m, 3H), 1.98-1.62 (m, 4H); ${ }^{13} \mathrm{C}-\mathrm{NMR}(101 \mathrm{MHz}$, DMSO-d $\left.{ }_{6}\right) \delta 156.9,156.6,153.8,137.3,128.7,123.8,120.3,119.9,118.5,110.7,96.0,56.6,53.2,52.9,49.1$, 48.4, 34.1, 26.7, 25.5, 14.9; ESI-MS: $(\mathrm{m} / \mathrm{z}) 381.2[\mathrm{M}+\mathrm{H}]^{+}, 403.2[\mathrm{M}+\mathrm{Na}]^{+}, 379.2[\mathrm{M}-\mathrm{H}]^{-}$; HPLC: $\mathrm{t}_{\mathrm{r}}=$ $4.362 \mathrm{~min}$ (99.9\% purity). Crystals suitable for X-ray determination were obtained by slow evaporation of a solution of $\mathbf{2 4}$ in methanol and chloroform at $298 \mathrm{~K}$ under atmospheric pressure. CCDC 1,917,242 contains the supplementary crystallographic data. These data can be obtained free of charge via http://www.ccdc.cam.ac.uk/conts/retrieving.html.

Supplementary Materials: The following are available online at: Comparison of JAK3 and GSK-3 $\beta$; MD Simulation of the $(3 \mathrm{a} R, 7 \mathrm{a} S)$-enantiomer of compound 24 ; ATP binding competition of $\mathbf{1 4} \mathbf{b}$; JAK3 inhibition by compounds 14b and 24; metabolism in HLM of compounds 14b and 24; structure determination of compound 24. The MD-movies, full-length raw-trajectories and the conformations used for $\mathrm{pK}_{\mathrm{a}}$ calculations are freely available at https://doi.org/10.5281/zenodo.3248885.

Author Contributions: S.A., T.P., F.A., M.K., M.F., D.S., S.A.L., and P.K. conceived and designed the experiments; S.A. performed synthesis; T.P. performed molecular modelling; F.A. and M.K. performed biological assays; M.F. performed preliminary synthetic experiments; D.S. performed X-ray crystallography; S.A., T.P., and P.K. analyzed the data; S.A., T.P. and P.K. wrote the paper.

Funding: This study was supported by the Federal Ministry of Education and Research (BMBF) within the BioPharma-Neuroallianz consortium (Neuro-T8B project). T.P. acknowledges the Orion Research Foundation sr for financial support.

Acknowledgments: The authors acknowledge Katharina Bauer and Jens Strobach for the biological assays of some synthesized compounds and the CSC-IT Center for Science, Finland, for computational resources.

Conflicts of Interest: The authors declare no conflict of interest.

\section{References}

1. Manning, G.; Whyte, D.B.; Martinez, R.; Hunter, T.; Sudarsanam, S. The protein kinase complement of the human genome. Science 2002, 298, 1912-1934. [CrossRef] [PubMed]

2. Manning, G.; Genomic Overview of Protein Kinases; WormBook. The C. Elegans Research Community, WormBook. Available online: http://www.wormbook.org (accessed on 13 December 2005). [CrossRef]

3. Sutherland, C. What Are the Bona fide GSK3 Substrates? Int. J. Alzheimer's Dis. 2011, 2011, 23.

4. Embi, N.; Rylatt, D.B.; Cohen, P. Glycogen synthase kinase-3 from rabbit skeletal muscle. Eur. J. Biochem. 1980, 107, 519-527. [CrossRef] [PubMed]

5. Wang, Y.; Roach, P.J. Inactivation of rabbit muscle glycogen synthase by glycogen synthase kinase-3. Dominant role of the phosphorylation of Ser-640 (site-3a). J. Biol. Chem. 1993, 268, 23876-23880. [PubMed]

6. Cohen, P.; Frame, S. The renaissance of GSK3. Nat. Rev. Mol. Cell Biol. 2001, 2, 769-776. [CrossRef]

7. Woodgett, J.R. Molecular cloning and expression of glycogen synthase kinase-3/factor A. Embo. J. 1990, 9, 2431-2438. [CrossRef] [PubMed]

8. MacAulay, K.; Doble, B.W.; Patel, S.; Hansotia, T.; Sinclair, E.M.; Drucker, D.J.; Nagy, A.; Woodgett, J.R. Glycogen Synthase Kinase 3 $\alpha$-Specific Regulation of Murine Hepatic Glycogen Metabolism. Cell Metab. 2007, 6, 329-337. [CrossRef]

9. Hoeflich, K.P.; Luo, J.; Rubie, E.A.; Tsao, M.-S.; Jin, O.; Woodgett, J.R. Requirement for glycogen synthase kinase-3 $\beta$ in cell survival and NF- $\mathrm{kB}$ activation. Nature 2000, 406, 86-90. [CrossRef]

10. Kerkela, R.; Kockeritz, L.; MacAulay, K.; Zhou, J.; Doble, B.W.; Beahm, C.; Greytak, S.; Woulfe, K.; Trivedi, C.M.; Woodgett, J.R.; et al. Deletion of GSK-3 $\beta$ in mice leads to hypertrophic cardiomyopathy secondary to cardiomyoblast hyperproliferation. J. Clin. Investig. 2008, 118, 3609-3618. [CrossRef]

11. Beurel, E.; Grieco, S.F.; Jope, R.S. Glycogen synthase kinase-3 (GSK3): Regulation, actions, and diseases. Pharmacol. Ther. 2015, 148, 114-131. [CrossRef]

12. Patel, P.; Woodgett, J.R. Chapter eight-Glycogen synthase kinase 3: A kinase for all pathways? In Current Topics in Developmental Biology; Jenny, A., Ed.; Academic Press: Cambridge, MA, USA, 2017; Volume 123, pp. 277-302. 
13. Flanagan, M.E.; Blumenkopf, T.A.; Brissette, W.H.; Brown, M.F.; Casavant, J.M.; Shang-Poa, C.; Doty, J.L.; Elliott, E.A.; Fisher, M.B.; Hines, M.; et al. Discovery of CP-690,550: A potent and selective Janus kinase (JAK) inhibitor for the treatment of autoimmune diseases and organ transplant rejection. J. Med. Chem. 2010, 53, 8468-8484. [CrossRef] [PubMed]

14. Clark, J.D.; Flanagan, M.E.; Telliez, J.B. Discovery and Development of Janus Kinase (JAK) inhibitors for inflammatory diseases. J. Med. Chem. 2014, 57, 5023-5038. [CrossRef] [PubMed]

15. Xeljanz: Highlights of Prescribing Information. Available online: https://www.accessdata.fda.gov/ drugsatfda_docs/label/2018/203214s018lbl.pdf (accessed on 19 March 2019).

16. Chrencik, J.E.; Patny, A.; Leung, I.K.; Korniski, B.; Emmons, T.L.; Hall, T.; Weinberg, R.A.; Gormley, J.A.; Williams, J.M.; Day, J.E.; et al. Structural and thermodynamic characterization of the TYK2 and JAK3 kinase domains in complex with CP-690550 and CMP-6. J. Mol. Biol. 2010, 400, 413-433. [CrossRef] [PubMed]

17. Sivaprakasam, P.; Han, X.; Civiello, R.L.; Jacutin-Porte, S.; Kish, K.; Pokross, M.; Lewis, H.A.; Ahmed, N.; Szapiel, N.; Newitt, J.A.; et al. Discovery of new acylaminopyridines as GSK-3 inhibitors by a structure guided in-depth exploration of chemical space around a pyrrolopyridinone core. Bioorg. Med. Chem. Lett. 2015, 25, 1856-1863. [CrossRef] [PubMed]

18. Jiang, J.K.; Ghoreschi, K.; Deflorian, F.; Chen, Z.; Perreira, M.; Pesu, M.; Smith, J.; Nguyen, D.T.; Liu, E.H.; Leister, W.; et al. Examining the chirality, conformation and selective kinase inhibition of 3-((3R,4R)-4-methyl-3-(methyl(7H-pyrrolo[2,3-d]pyrimidin-4-yl)amino)piperidin-1-yl)-3-oxopropanenitrile (CP-690,550). J. Med. Chem. 2008, 51, 8012-8018. [CrossRef]

19. Fleming, F.F.; Yao, L.; Ravikumar, P.C.; Funk, L.; Shook, B.C. Nitrile-containing pharmaceuticals: Efficacious roles of the nitrile pharmacophore. J. Med. Chem. 2010, 53, 7902-7917. [CrossRef] [PubMed]

20. Wang, Y.; Du, Y.; Huang, N. A survey of the role of nitrile groups in protein-ligand interactions. Future Med. Chem. 2018, 10, 2713-2728. [CrossRef]

21. Heider, F.; Ansideri, F.; Tesch, R.; Pantsar, T.; Haun, U.; Döring, E.; Kudolo, M.; Poso, A.; Albrecht, W.; Laufer, S.A.; et al. Pyridinylimidazoles as dual glycogen synthase kinase $3 \beta /$ p38 $\alpha$ mitogen-activated protein kinase inhibitors. Eur. J. Med. Chem. 2019, 175, 309-329. [CrossRef]

22. Zegzouti, H.; Zdanovskaia, M.; Hsiao, K.; Goueli, S.A. ADP-Glo: A bioluminescent and homogeneous ADP monitoring assay for kinases. Assay Drug Dev. Technol. 2009, 7, 560-572. [CrossRef]

23. Ghose, A.K.; Viswanadhan, V.N.; Wendoloski, J.J. Prediction of hydrophobic (lipophilic) properties of small organic molecules using fragmental methods: An analysis of ALOGP and CLOGP methods. J. Phys. Chem. A 1998, 102, 3762-3772. [CrossRef]

24. Roos, K.; Wu, C.; Damm, W.; Reboul, M.; Stevenson, J.M.; Lu, C.; Dahlgren, M.K.; Mondal, S.; Chen, W.; Wang, L.; et al. OPLS3e: Extending force field coverage for drug-like small molecules. J. Chem. Theory Comput. 2019, 15, 1863-1874. [CrossRef] [PubMed]

25. Bauer, S.M.; Gehringer, M.; Laufer, S.A. A direct enzyme-linked immunosorbent assay (ELISA) for the quantitative evaluation of Janus Kinase 3 (JAK3) inhibitors. Anal. Methods 2014, 6, 8817-8822. [CrossRef]

26. Bourdonnec, B.L.; Leister, L.K.; Ajello, C.A.; Cassel, J.A.; Seida, P.R.; O’Hare, H.; Gu, M.; Chu, G.-H.; Tuthill, P.A.; DeHaven, R.N.; et al. Discovery of a series of aminopiperidines as novel iNOS inhibitors. Bioorg. Med. Chem. Lett. 2008, 18, 336-343. [CrossRef] [PubMed]

27. Showalter, H.D.H.; Bridges, A.J.; Zhou, H.; Sercel, A.D.; McMichael, A.; Fry, D.W. Tyrosine kinase inhibitors. 16. 6,5,6-tricyclic benzothieno[3,2-d]pyrimidines and pyrimido[5,4-b]- and -[4,5-b]indoles as potent inhibitors of the epidermal growth factor receptor tyrosine kinase. J. Med. Chem. 1999, 42, 5464-5474. [CrossRef] [PubMed]

28. Tichý, M.; Pohl, R.; Xu, H.Y.; Chen, Y.-L.; Yokokawa, F.; Shi, P.-Y.; Hocek, M. Synthesis and antiviral activity of 4,6-disubstituted pyrimido[4,5-b]indole ribonucleosides. Bioorg. Med. Chem. 2012, 20, 6123-6133. [CrossRef] [PubMed]

29. Tichý, M.; Pohl, R.; Tloušt'ová, E.; Weber, J.; Bahador, G.; Lee, Y.-J.; Hocek, M. Synthesis and biological activity of benzo-fused 7-deazaadenosine analogues. 5- and 6-substituted 4-amino- or 4-alkylpyrimido[4,5-b]indole ribonucleosides. Bioorg. Med. Chem. 2013, 21, 5362-5372. [CrossRef] [PubMed] 
30. Zhao, Y.; Bai, L.; Liu, L.; McEachern, D.; Stuckey, J.A.; Meagher, J.L.; Yang, C.-Y.; Ran, X.; Zhou, B.; $\mathrm{Hu}, \mathrm{Y}$; et al. Structure-based discovery of 4-(6-methoxy-2-methyl-4-(quinolin-4-yl)-9H-pyrimido[4,5- $b$ ]indol7-yl)-3,5-dimethylisoxazole (cd161) as a potent and orally bioavailable bet bromodomain inhibitor. J. Med. Chem. 2017, 60, 3887-3901. [CrossRef] [PubMed]

31. Reader, J.C.; Matthews, T.P.; Klair, S.; Cheung, K.-M.J.; Scanlon, J.; Proisy, N.; Addison, G.; Ellard, J.; Piton, N.; Taylor, S.; et al. Structure-guided evolution of potent and selective chk1 inhibitors through scaffold morphing. J. Med. Chem. 2011, 54, 8328-8342. [CrossRef]

32. Arnott, E.A.; Chan, L.C.; Cox, B.G.; Meyrick, B.; Phillips, A. POCl 3 chlorination of 4-quinazolones. J. Org. Chem. 2011, 76, 1653-1661. [CrossRef]

33. $\mathrm{Xu}, \mathrm{H}$.; Fan, L.-L. One-pot $N$-arylation of indoles directly from $N$-arylsulfonylindoles via consecutive deprotection and $S_{N}$ Ar reactions with activated aryl halides. Chem. Pharm. Bull. 2009, 57, 321-323. [CrossRef]

34. Kulagowski, J.J.; Blair, W.; Bull, R.J.; Chang, C.; Deshmukh, G.; Dyke, H.J.; Eigenbrot, C.; Ghilardi, N.; Gibbons, P.; Harrison, T.K.; et al. Identification of Imidazo-pyrrolopyridines as novel and potent JAK1 inhibitors. J. Med. Chem. 2012, 55, 5901-5921. [CrossRef] [PubMed]

35. Guo, Q.; Yu, C.; Zhang, C.; Li, Y.; Wang, T.; Huang, Z.; Wang, X.; Zhou, W.; Li, Y.; Qin, Z.; et al. Highly selective, potent, and oral mtor inhibitor for treatment of cancer as autophagy inducer. J. Med. Chem. 2018, 61, 881-904. [CrossRef] [PubMed]

36. Gehringer, M.; Pfaffenrot, E.; Bauer, S.; Laufer, S.A. Design and Synthesis of tricyclic jak3 inhibitors with picomolar affinities as novel molecular probes. ChemMedChem 2014, 9, 277-281. [CrossRef] [PubMed]

37. Hopkins, B.T.; Scott, D.; Conlon, P.; Jenkins, T.J.; Powell, N.; Guan, B.; Curervo, J.H.; Wang, D.; Taveras, A. Heterocyclic tyrosine kinase inhibitors. Patent WO2012058645A1, 3 May 2012.

38. Thorarensen, A.; Dowty, M.E.; Banker, M.E.; Juba, B.; Jussif, J.; Lin, T.; Vincent, F.; Czerwinski, R.M.; Casimiro-Garcia, A.; Unwalla, R.; et al. Design of a janus kinase 3 (JAK3) specific inhibitor 1-((2S,5R)-5-((7H-Pyrrolo[2,3-d]pyrimidin-4-yl)amino)-2-methylpiperidin-1-yl)prop-2-en-1-one (PF-06651600) allowing for the interrogation of JAK3 signaling in humans. J. Med. Chem. 2017, 60, 1971-1993. [CrossRef] [PubMed]

39. Eid, S.; Turk, S.; Volkamer, A.; Rippmann, F.; Fulle, S. KinMap: A web-based tool for interactive navigation through human kinome data. BMC Bioinf. 2017, 18, 16. [CrossRef] [PubMed]

40. Bateman, A.; Martin, M.J.; Orchard, S.; Magrane, M.; Alpi, E.; Bely, B.; Bingley, M.; Britto, R.; Bursteinas, B.; Busiello, G.; et al. UniProt: A worldwide hub of protein knowledge. Nucleic Acids Res. 2019, 47, D506-D515.

41. Sievers, F.; Higgins, D.G. Clustal omega for making accurate alignments of many protein sequences. Protein Sci. 2018, 27, 135-145. [CrossRef]

42. Sievers, F.; Wilm, A.; Dineen, D.; Gibson, T.J.; Karplus, K.; Li, W.Z.; Lopez, R.; McWilliam, H.; Remmert, M.; Soding, J.; et al. Fast, scalable generation of high-quality protein multiple sequence alignments using Clustal Omega. Mol. Syst. Biol. 2011, 7, 539. [CrossRef]

43. Bochevarov, A.D.; Watson, M.A.; Greenwood, J.R.; Philipp, D.M. Multiconformation, density functional theory-based $\mathrm{pk}_{\mathrm{a}}$ prediction in application to large, flexible organic molecules with diverse functional groups. J. Chem. Theory Comput. 2016, 12, 6001-6019. [CrossRef]

44. Klicić, J.J.; Friesner, R.A.; Liu, S.-Y.; Guida, W.C. Accurate prediction of acidity constants in aqueous solution via density functional theory and self-consistent reaction field methods. J. Phys. Chem. A 2002, 106, 1327-1335. [CrossRef]

45. Yu, H.S.; Watson, M.A.; Bochevarov, A.D. Weighted averaging scheme and local atomic descriptor for $\mathrm{pk}_{\mathrm{a}}$ prediction based on density functional theory. J. Chem. Inf. Model. 2018, 58, 271-286. [CrossRef] [PubMed]

46. Sastry, G.M.; Adzhigirey, M.; Day, T.; Annabhimoju, R.; Sherman, W. Protein and ligand preparation: Parameters, protocols, and influence on virtual screening enrichments. J. Comput.-Aided Mol. Des. 2013, 27, 221-234. [CrossRef] [PubMed]

47. Bowers, K.J.; Edmond, C.; Xu, H.; Dror, R.O.; Eastwood, M.P.; Gregerson, B.A.; Klepeis, J.L.; Kolossvary, I.; Moraes, M.A.; Sacerdoti, F.D.; et al. Scalable algorithms for molecular dynamics simulations on commodity clusters. In Proceedings of the ACM/IEEE Conference on Supercomputing (SC06), Tampa, FL, USA, 11-17 November 2006; IEEE: Tampa, FL, USA, 2006. 
48. Jorgensen, W.L.; Chandrasekhar, J.; Madura, J.D.; Impey, R.W.; Klein, M.L. Comparison of simple potential functions for simulating liquid water. J. Chem. Phys. 1983, 79, 926-935. [CrossRef]

49. Gehringer, M.; Forster, M.; Pfaffenrot, E.; Bauer, S.M.; Laufer, S.A. Novel hinge-binding motifs for janus kinase 3 inhibitors: A comprehensive structure-activity relationship study on tofacitinib bioisosteres. Chem. Med. Chem. 2014, 9, 2516-2527. [CrossRef]

Sample Availability: Samples of the compounds are not available from the authors.

(C) 2019 by the authors. Licensee MDPI, Basel, Switzerland. This article is an open access article distributed under the terms and conditions of the Creative Commons Attribution (CC BY) license (http://creativecommons.org/licenses/by/4.0/). 